Ash-flow Tuffs of the Galiuro Volcanics in the Northern Galiuro Mountains, Pinal County, Arizona
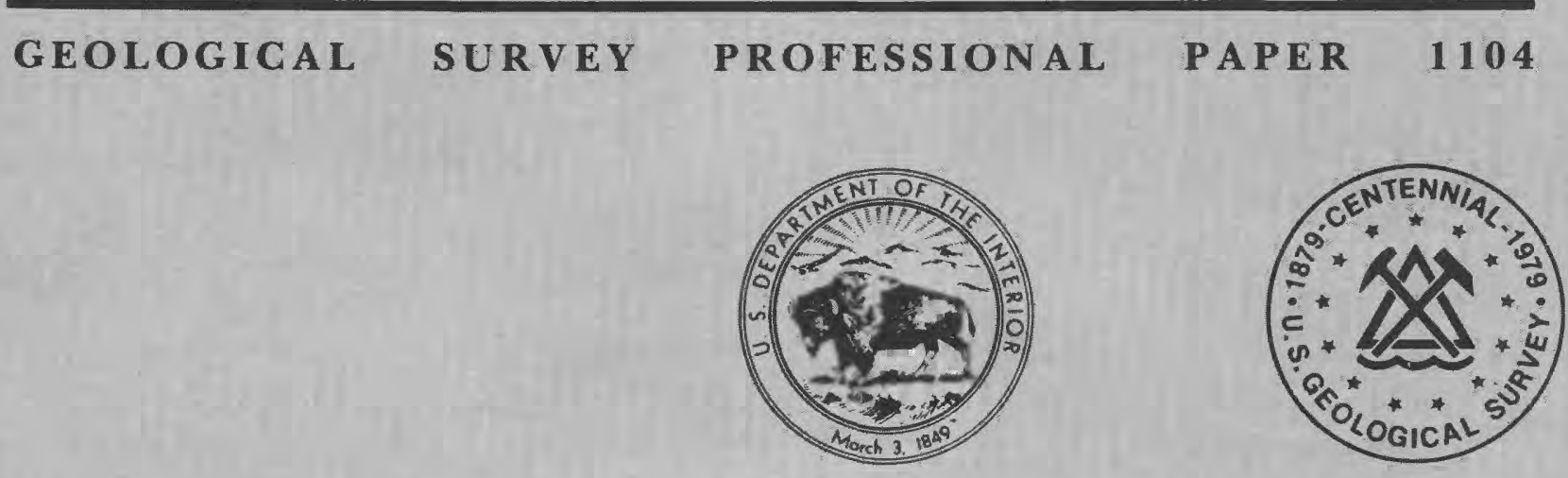


\section{Ash-flow Tuffs of the Galiuro Volcanics in the Northern Galiuro Mountains, Pinal County, Arizona}

By MEDORA H. KRIEGER

\section{GEOLOGIGAL SURVEY PROFESSIONAL PAPER 1104}

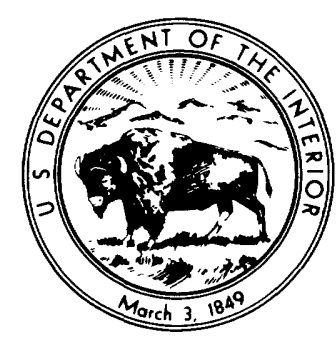

\begin{tabular}{lllllll}
\hline UNITED & STATES & GOVERNMENT & PRINTING & OFFICE, & WASHINGTON & :
\end{tabular} 
UNITED STATES DEPARTMENT OF THE INTERIOR

CECIL D. ANDRUS, Secretary

\section{GEOLOGICAL SURVEY}

H. William Menard, Director

Library of Congress Cataloging in Publication Data

Krieger, Medora Louise Hooper, 1905-

Ash-flow tuffs of the Galiuro Volcanics in the northern Galiuro Mountains, Pinal County, Arizona.

(Geological Survey Professional paper ; 1104)

Bibliography: p. 32.

1. Volcanic ash, tuff, etc.-Arizona-Galiuro Mountains. I. Title.

II. Series: United States. Geological Survey. Professional paper; 1104. QE461.K757 $552^{\prime} \cdot 2$

79-19484

For sale by the Superintendent of Documents, U.S. Government Printing Office Washington, D.C. 20402

Stock number 024-001-03239-2 


\section{CONTENTS}

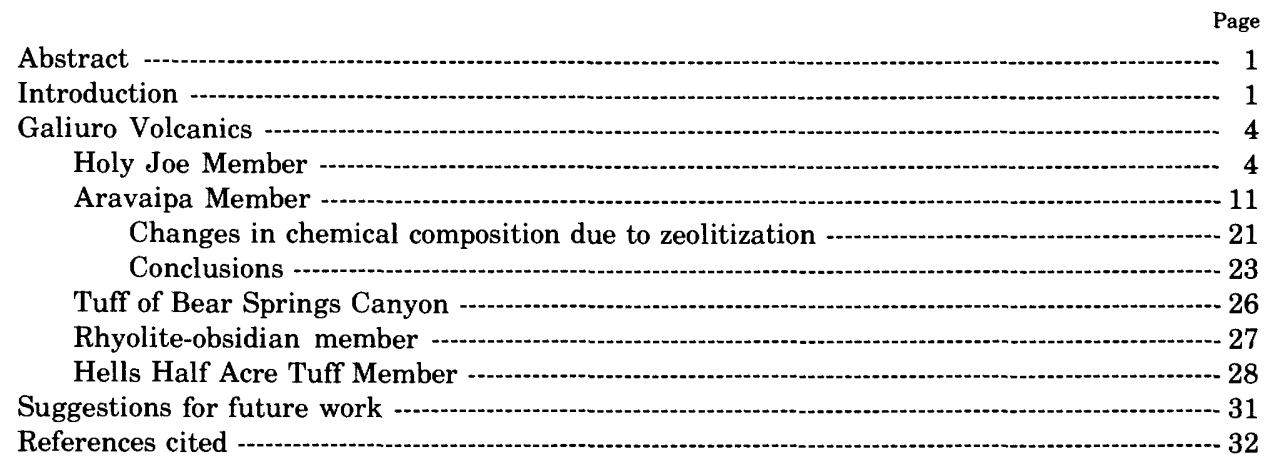

\section{ILLUSTRATIONS}

age

1

1

21

23

26

31 
TABLES

\section{TABLES}

TABLE 1. Potassium-argon ages of ash-flow tuffs in Galiuro Volcanics in the northern Galiuro Mountains -..................................... 3

2. Modes of Holy Joe Member -

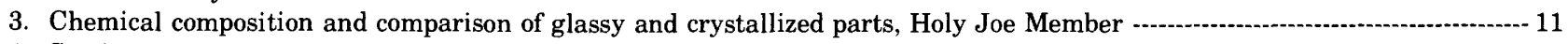

4. Semiquantitative spectrographic analyses of minor elements in ash-flow tuffs and rhyolite-obsidian member, northern Galiuro Mountains -

5. Modes of Aravaipa Member

6. Chemical composition and comparison of glassy and crystallized parts, Aravaipa Member

7. Chemical composition and comparison of zeolitized and nonzeolitized rocks 


\title{
ASH-FLOW TUFFS OF THE GALIURO VOLCANICS IN THE NORTHERN GALIURO MOUNTAINS, PINAL COUNTY, ARIZONA
}

\author{
By Medora H. KRIEGER
}

\begin{abstract}
The upper Oligocene and lower Miocene Galiuro Volcanics in the northern part of the Galiuro Mountains contains two distinctive major ash-flow tuff sheets, the Holy Joe and Aravaipa Members. These major ash-flows illustrate many features of ash-flow geology not generally exposed so completely. The Holy Joe Member, composed of a series of densely welded flows of quartz latite composition that make up a simple cooling unit, is a rare example of a cooling unit that has a vitrophyre at the top as well as at the base. The upper vitrophyre does not represent a cooling break. The Aravaipa Member, a rhyolite, is completely exposed in Aravaipa and other canyons and on Table Mountain. Remarkable exposures along Whitewash Canyon exhibit the complete change from a typical stacked-up interior zonation of an ash flow to a nonwelded distal margin. Vertical and horizontal changes in welding, crystallization, specific gravity, and lithology are exposed. The ash flow can be divided into six lithologic zones.

The Holy Joe and Aravaipa Members of the Galiuro Volcanics are so well exposed and so clearly show characteristic features of ash-flow tuffs that they could be a valuable teaching aid and a source of theses for geology students.
\end{abstract}

\section{INTRODUCTION}

The upper Oligocene and lower Miocene Galiuro Volcanics consists of andesitic to rhyolitic flows, tuffs, and ash-flow tuffs. Included in the sequence in the northern part of the Galiuro Mountains are two distinctive major ash-flow tuff sheets and two minor ash flows. The major ash-flow tuff sheets provide an excellent example of contrast in types of emplacement, cooling and crystallization history, and later alteration, and they illustrate some features in ash-flow tuffs not normally seen or exposed so completely. The older one has a vitrophyre at the top as well as at the bottom of a sequence of ash flows that cooled as a unit. The younger one, also a simple cooling unit, has a well-developed horizontal and vertical zonation that suggests a single ash flow, but that may represent at least two additional pulses. The nonwelded distal margin has been zeolitized.

The Galiuro Volcanics extends from the southern part of the Christmas quadrangle to the northern part of the Dragoon quadrangle (fig. 1). The first detailed descriptions of the Galiuro Volcanics were by Cooper and Silver (1964) in the Dragoon quadrangle and by Simons (1964) in the Klondyke quadrangle. Blake (1902) had previously used the term Galiuro Rhyolite for tuffs and lavas in the central part of the Galiuro Mountains. Willden (1964) published a generalized geologic map of the Christmas quadrangle but he did not correlate the volcanic rocks with the Galiuro Volcanics. Detailed subdivisions of the volcanic rocks in the northern Galiuro Mountains-the Holy Joe Peak

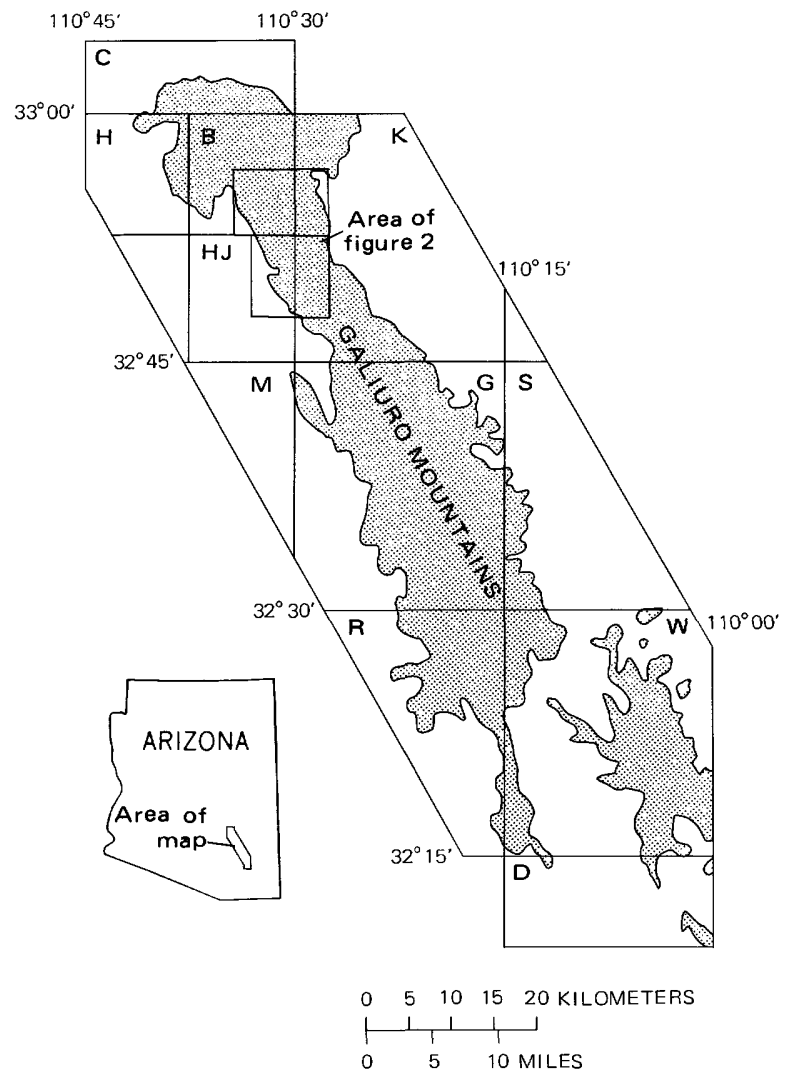

FIGURE 1.-Distribution of Galiuro Volcanics (shaded), 15minute quadrangles: Christmas (C), Dragoon (D), Galiuro Mountains (G), Holy Joe Peak (H), Klondyke (K), Mammoth (M), Reddington (R), Sierra Bonita Ranch (S), Winchester Mountains (W), and 71/2-minute quadrangles; Brandenburg Mountain (B) and Holy Joe Peak (HJ). 


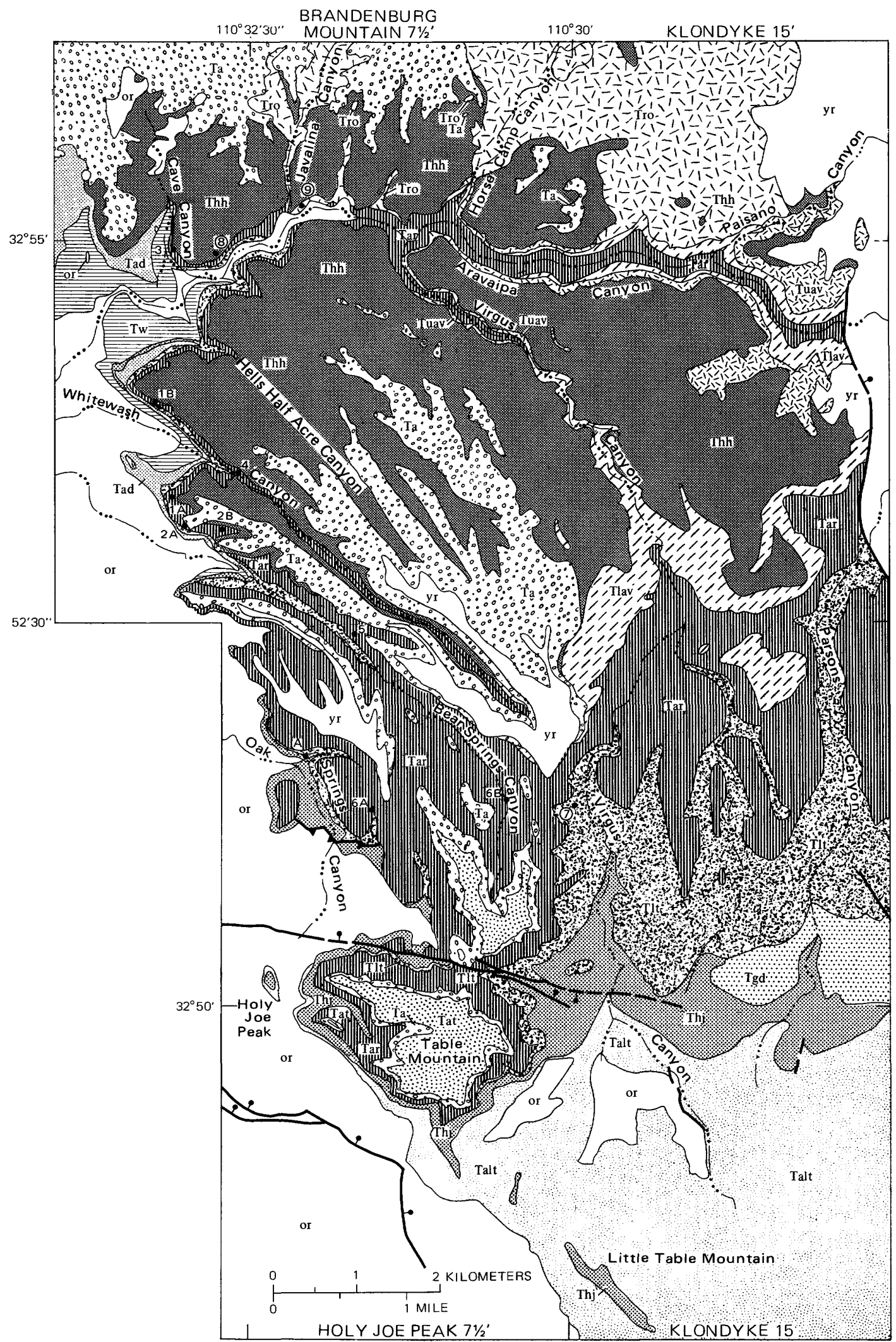

FIGURE 2.-Geologic map of parts of Brandenburg Mountain, Holy Joe Peak, and Klondyke quadrangles (modified from Krieger, 1968a, b; and Simons, 1964). 


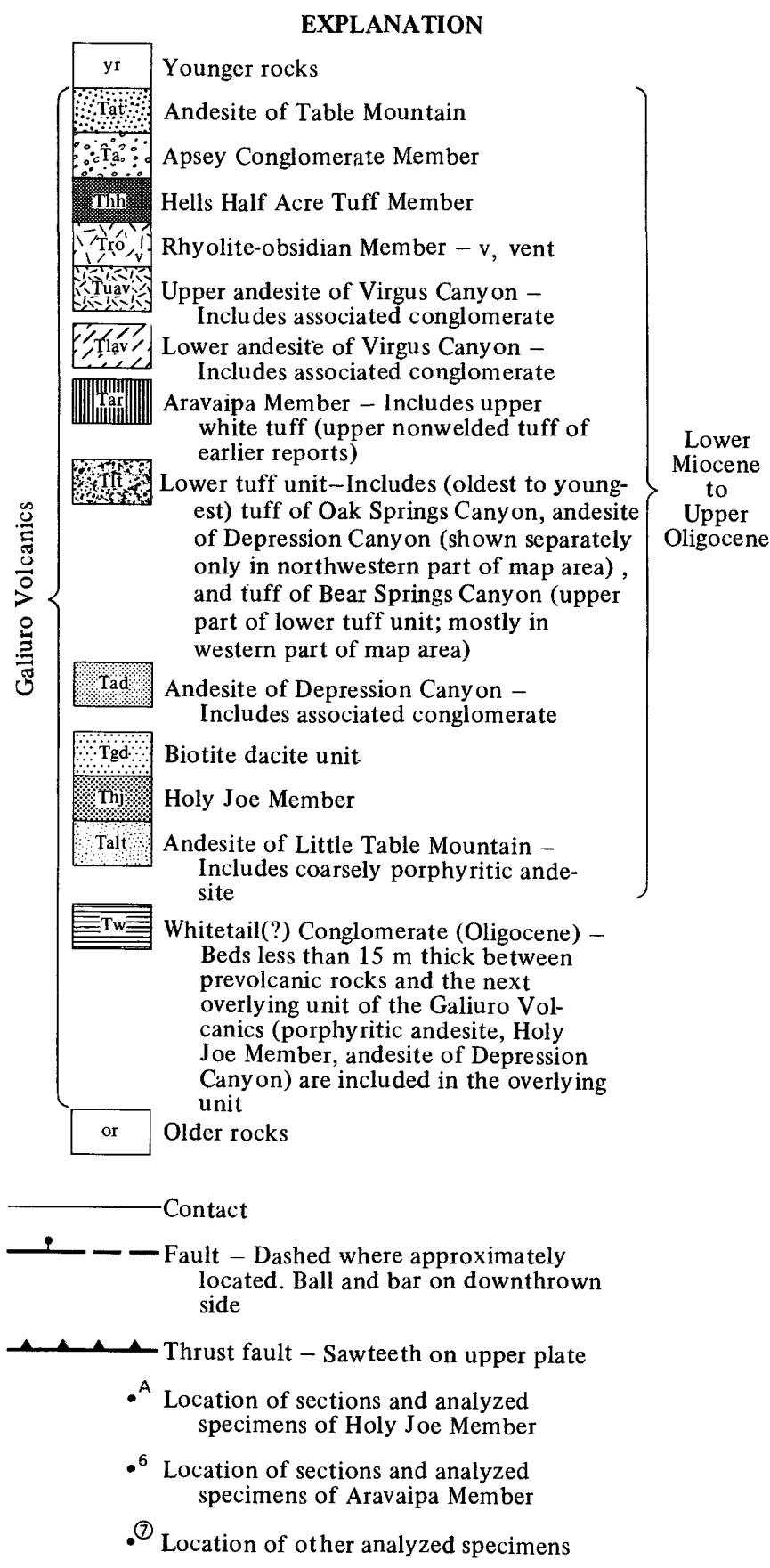

FIGURE 2.-Continued.

quadrangle ${ }^{1}$-were mapped by Krieger (1968a, b); S. C. Creasey (unpub. data) mapped in reconnaissance the central Galiuro Mountains, which contains the thickest section of the formation. The stratigraphy, lithology, chemical composition, and age of the Galiuro Volcanics are summarized by Creasey and Krieger (1978). The formation can be separated into two parts by an erosional unconformity. The lower part is pre-

\footnotetext{
${ }^{1}$ Holy Joe Peak in this report refers to the 15-minute quadrangle; four geologic maps cover this area (Krieger, 1968a-d). The ash-flow tuffs discussed in this report are in the Brandenburg Mountain and Holy Joe Peak $71 / 2$-minute quadrangles and the Klondyke quadrangle; discussion is largely limited to the two $7 \frac{1}{1} 2$-minute quadrangles.
}

dominantly andesite to rhyodacite flows but it contains three ash-flow tuffs. The upper part is chiefly ash-flow tuffs, but it includes andesite flows and two areas of rhyolite-obsidian flows and domes, one of which is in the northern Galiuro Mountains. The distribution of the Galiuro Volcanics in parts of the Holy Joe Peak and Klondyke quadrangles, which is shown in figure 2, is modified from the published geologic maps. The terminology used in each area and my interpretation of the relations of members or units in the Klondyke and Holy Joe Peak quadrangles and in the Christmas quadrangle to the north are given in figure 3 .

The two major ash-flow tuff sheets-Holy Joe and Aravaipa Members-and the two minor ones-tuff of Bear Springs Canyon and Hells Half Acre Tuff Member-illustrate many features of ash-flow geology. The Holy Joe Member rests on the unconformity that separates the volcanics into two parts, the tuff of Bear Springs Canyon underlies the Aravaipa Member, and the Hells Half Acre Tuff Member is in the upper part of the formation. The ages of the ash-flow tuffs are given in table 1.

The Holy Joe Member is composed of a series of densely welded flows of quartz latite composition that make up a simple cooling unit (Smith, 1960a). It is a rare example of a cooling unit that has a vitrophyre at the top as well as at the base. The major zones recognized are, in ascending order: the lower vitrophyre, lower devitrified zone, central vapor-phase zone, upper devitrified zone, and upper vitrophyre. The absence of breaks in crystallization across flow boundaries and the gradation between zones and from crystallized to vitric material at the top indicate a single cooling unit. Dense welding and fairly uniform high specific gravity throughout the member indicate that the individual flows were hot.

The Aravaipa Member, of rhyolite composition, has a well-developed zonation that indicates a simple cooling unit and possibly a single ash flow. It presents a classic example of ash-flow geology, in that the complete change from the stacked-up zonation typical of the interior of the ash flow to the nonwelded distal margin, now zeolitized, is completely exposed in some canyon walls. Horizontal and vertical zonation in ash-flow tuffs was first recognized by Smith (1960b).

TABLE 1.-Potassium-argon ages of ash-flow tuffs in the Galiuro Volcanics in the northern Galiuro Mountains (in millions of years)

[From Creasey and Krieger, 1978]

\begin{tabular}{|c|c|c|}
\hline Member & Biotite & Sanidine \\
\hline Hells Half Acre Tuff Member ----- & $24.6 \pm 0.7$ & $22.5 \pm 0.7$ \\
\hline Aravaipa Member & $25.7 \pm 0.7$ & $22.9 \pm 0.8$ \\
\hline Tuff of Bear Springs Canyon ${ }^{1}$ & $23.8 \pm 0.7$ & -- \\
\hline Holy Joe Member & $26.5 \pm 0.8$ & $25.6 \pm 0.8$ \\
\hline
\end{tabular}
1This analysis may be from one of the underlying tuffs in the lower tuff unit of Simons
(1964 (1964, p. 81). 


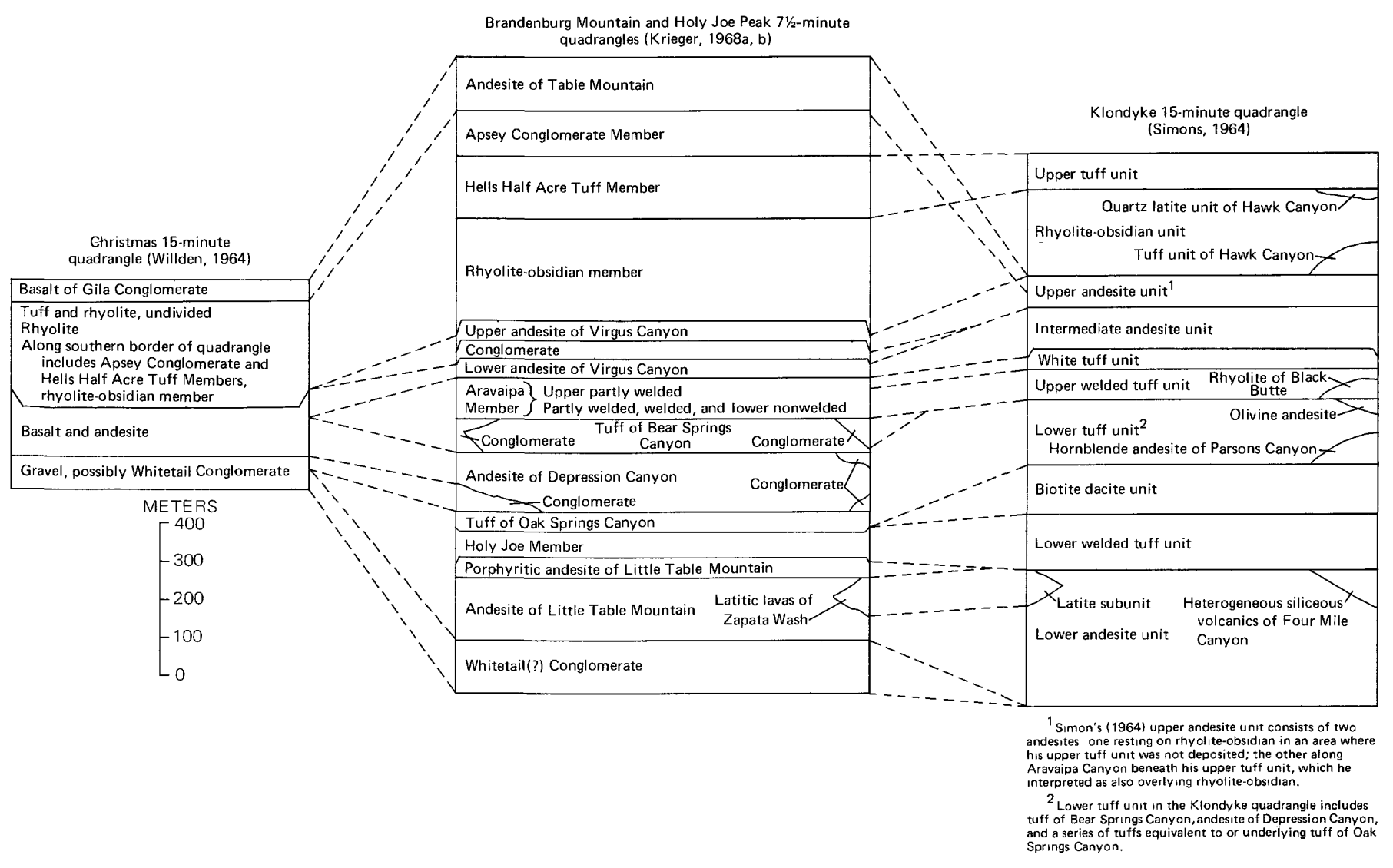

FIGURE 3.-Correlation chart showing relations of stratigraphic units in Galiuro Volcanics, Christmas, Brandenburg Mountain, Holy Joe Peak, and Klondyke quadrangles. Shows maximum thickness of members or units in each area.

Suites of specimens were collected from a section vertically across the Holy Joe Member and from six vertical sections across the Aravaipa Member from the interior to near the distal margin. Changes in lithology, welding, crystallization, specific gravity, and composition are shown in tables and diagrammatic sketches. Data obtained from chemical analyses of selected specimens and from X-ray diffractographs of all specimens are presented.

Acknowledgments-I thank my colleagues of the U.S. Geological Survey for their important contributions and stimulating discussions of ash-flow problems. Special thanks are due R. L. Smith and D. W. Peterson for interpreting and first pointing out many of the distinctive features of the ash flows in the northern Galiuro Mountains and to S. C. Creasey and F. S. Simons for data on the volcanic rocks in adjacent areas. D. W. Peterson, E. D. McKee, E. W. Heldreth, and M. G. Johnson made many helpful comments and suggestions during preparation of the manuscript.

\section{GALIURO VOLCANICS HOLY JOE MEMBER}

The Holy Joe Member of the Galiuro Volcanics crops out intermittently from $13 \mathrm{~km}$ west of to $8 \mathrm{~km}$ east of the boundary between the Holy Joe Peak and Klondyke quadrangles (Krieger, 1968a, b; Simons, 1964) and from the northernmost latitude of Aravaipa Canyon to south of the latitude of Little Table Mountain (fig. 2); it also crops out on a butte about $10 \mathrm{~km}$ south of Little Table Mountain. It may extend for many kilometers to the south. Its source is unknown. The member is about $100 \mathrm{~m}$ thick in the Klondyke quadrangle (Simons, 1964). Its maximum thickness around Table Mountain (fig. 2) in the Holy Joe Peak quadrangle (Krieger, 1968b) is about $80 \mathrm{~m}$; to the north, the lower part, and locally all of it, laps out against prevolcanic topographic highs.

The Holy Joe Member is a cliff-forming unit that has strong horizontal partings (fig. 4), has a rather uniform appearance, and is pale brown to pale red throughout most of its thickness, except for a thin nearly white nonwelded tuff and a dark vitrophyre at the base and another dark vitrophyre at the top. The ash-flow tuff between the lower and upper vitrophyres can be divided into three lithologic zones: lower devitrified zone, central vapor-phase zone, and upper devitrified zone. The lower vitrophyre is dark gray, except for the basal part, which is brown due to oxidation. The lower 


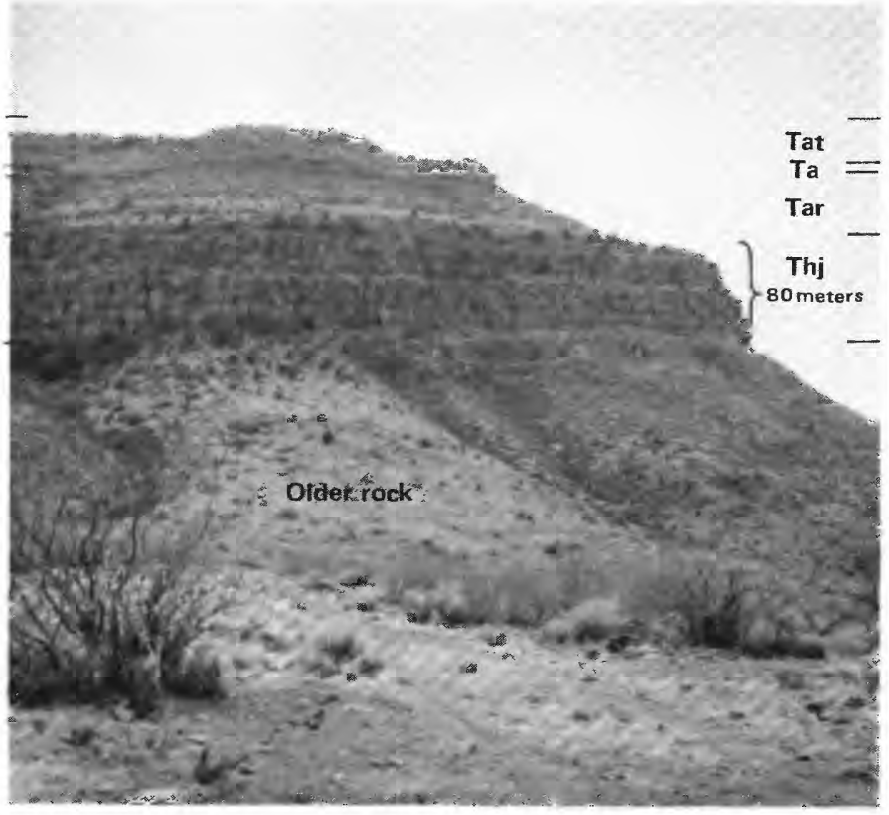

FIGURE 4.-Typical exposure of Holy Joe Member, northwest end of Table Mountain, as viewed from northeast. Horizontal partings probably represent individual flows and possibly zones of denser welding. Andesite of Table Mountain (Tat); Apsey Conglomerate Member (Ta); Aravaipa Member (Tar); Holy Joe Member (Thj).

devitrified zone is reddish brown, and the upper one is slightly redder. The vapor-phase zone is brown to pale red except for the middle part, which is light brownish gray. The lower part of the upper vitrophyre is dark gray, and the upper part is red. Black glassy flattened pumice lapilli contrast with the red of the upper vitrophyre and the brown of the lower vitrophyre. The transition from the lower vitrophyre to the lower devitrified zone is abrupt, but that between all the other zones is gradational. Dense welding is characteristic of all the zones except the basal nonwelded zone.

A suite of specimens (H201A-Q) was collected vertically across the ash-flow sheet in Oak Springs Canyon (fig. 2, loc. A). The elevation above base, field units, color, zones of welding and crystallization, mineralogic composition (based on X-ray diffractographs), and specific gravities of these specimens are summarized in figure 5. The Holy Joe Member is composed of shards and pumice lapilli, very tiny crystal fragments of feldspar, quartz, and biotite, and some foreign rock and mineral fragments (table 2). Phenocrysts make up about 7 percent of the rock, and feldspar, mostly plagioclase, makes up about 71 percent of the phenocrysts. Chemical analyses (see table 3 ) indicate a quartz latite composition.

Photomicrographs (figs. $6 A-J$ ) of selected thin sections of the suite of specimens illustrate typical microscopic features of the ash-flow sheet. The basal nonwelded tuff contains undeformed shards and glass bubbles (not illustrated). All the rocks above the nonwelded tuff show evidence of dense welding, eutaxitic texture due to flattening and alinement of pumice lapilli and shards (figs. $6 B, C, E$ ), collapse of pumice with elimination of most pore space but retention of pumice structure in frayed-out ends (fig. 6A), and molding of pumice and shards against phenocrysts or crystal and lithic fragments (figs. $6 A, I, J$ ). Shard structure (figs. $6 B, C, E, G, I)$ is preserved in vitrophyres and in most of the crystallized tuff owing to fine-grained axiolitic intergrowths (too small to show at scale of photomicrographs) of cristobalite and sanidine, the products of devitrification. Outlines of pumice lapilli are generally preserved, but their structure may be destroyed by spherulitic intergrowths around trapped gas in cavities (figs. $6 D, F, H$ ).

All the tuff between the lower and upper vitrophyre is devitrified, as shown by its nonvitric (stony or lithoidal) character, by a finely crystalline groundmass (composed of cristobalite and sanidine; see below), and by the alteration of biotite. The vapor-phase zone, in which cristobalite and sanidine are also characteristic, is recognized by its lighter color, the slightly cavernous appearance of pumice lapilli in both hand specimen and thin section (figs. $6 D, F$ ), and the presence of discrete microscopic crystals of tridymite in cavities. Crystallization in this zone is not as coarse grained as in less densely welded ash flows and is confined largely to pumice lapilli.

In addition to the study of hand specimens and thin sections, each specimen was X-rayed; the results are shown in the composition column in figure 5. X-ray diffractographs of the ash flows show not only the phenocrysts (feldspar, quartz, and biotite) but also the devitrification products (cristobalite and feldspar) and the alteration products (clay and zeolite). Because-of preferred orientations, degrees of crystallinity, masking by noncrystallized material, mass absorption, and other problems, quantitative results are impossible to obtain. The X-ray diffractographs show the apparent abundance of the constituents and are useful in identifying them, especially where thin sections were not available, as in parts of the Aravaipa Member. A few diffractographs of selected specimens of the Holy Joe and Aravaipa Members (fig. 7) are included to illustrate the type of peak heights involved. Noncrystalline material, such as glass in the vitric parts of the ash flow, is recognized as a "glass hump" (fig. 7A). Cristobalite is readily recognized by its characterıstic peak (figs. $7 B, C$ ). Sanidine and plagioclase can be distinguished by careful comparisons of the patterns with patterns prepared from pure mineral separates; they are identified only as feldspar in figure 7. Tridymite was not definitely recognized in the X-ray diffracto- 


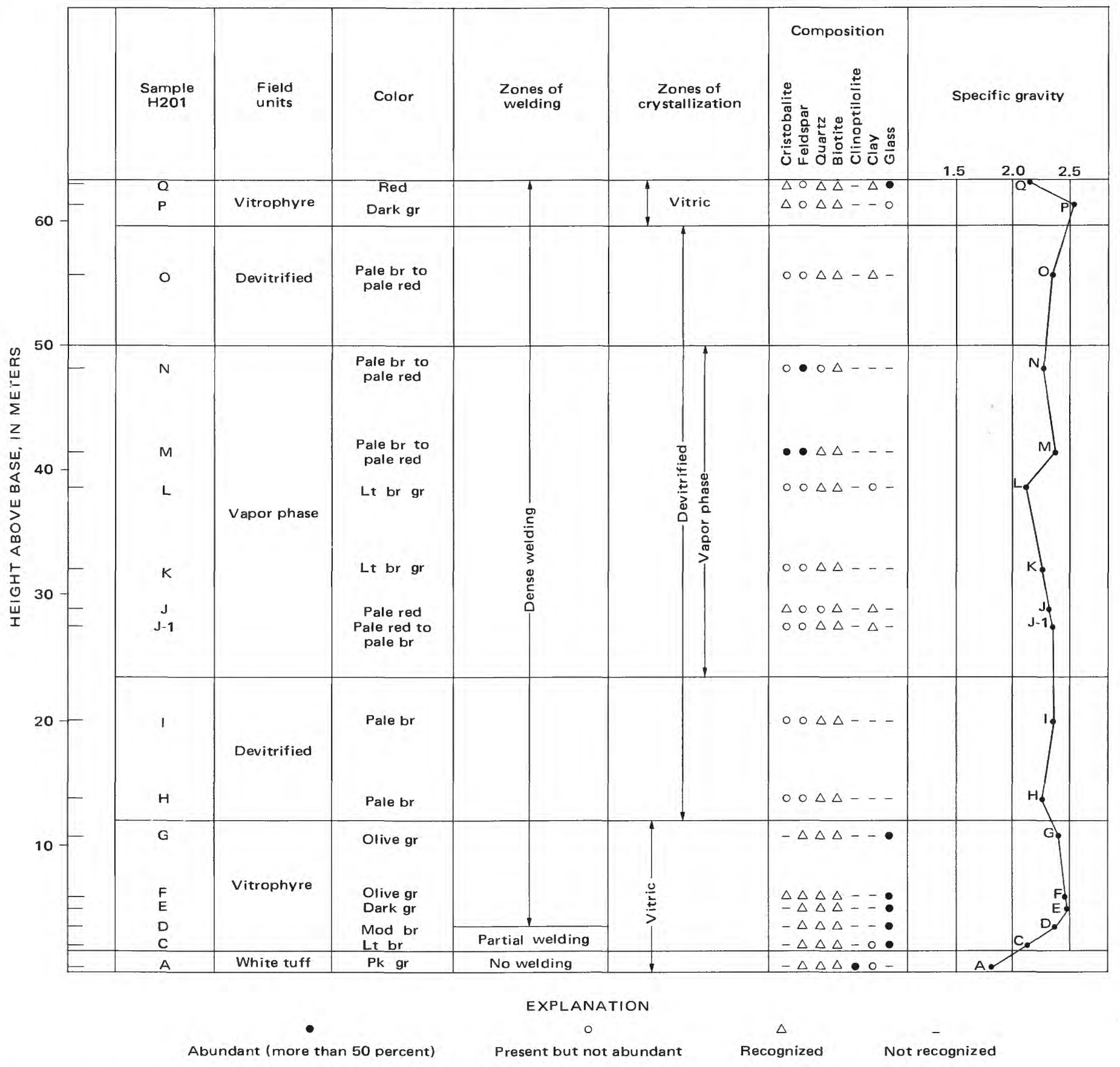

Figure 5.-Some physical characteristics of the Holy Joe Member, based on specimens H201A-Q, collected at location A (fig. 2). Model data in table 2; chemical analyses of specimens F, H, and $\mathrm{K}$ in table 3. Color terms: br, brown or brownish; gr, gray; lt, light; mod, moderate; pk, pinkish. Mineral abundance estimated from X-ray diffractographs of bulk samples. In addition to listed minerals, samples J-1 through $\mathrm{N}$ contained tridymite.

graphs because it is a very minor constituent and its peaks (figs. $7 B, C$ ) are close to some of the peaks of cristobalite, quartz, and feldspar. X-rays are the basis for most modern identification of zeolites in tuffs and sedimentary rocks. The zeolite, clinoptilolite, was recognized only in the X-ray of the basal nonwelded tuff (see composition column, fig. 5); clinoptilolite extensively replaced the nonwelded distal parts of the Aravaipa Member (fig. $7 E$ ).

Chemical analyses were made for samples from three different zones in the Holy Joe Member; the lower vitrophyre, lower devitrified zone, and the gray 
TABLE 2.-Modes of Holy Joe Member

[Modes in volume percent. Based on thin-section studies of specimens collected vertically across the member in Oak Springs Canyon (loc. A, fig. 2); see fig. 5 for other characteristics. Field units: uv, upper vitrophyre; ud, upper devitrified; vp, vapor phase; ld, lower devitrified; lv, lower vitrophyre]

\begin{tabular}{|c|c|c|c|c|c|c|c|c|c|c|c|}
\hline \multirow{3}{*}{$\begin{array}{l}\text { Field } \\
\text { No. } \\
\end{array}$} & \multirow{3}{*}{$\begin{array}{l}\text { Field } \\
\text { unit }\end{array}$} & \multicolumn{8}{|c|}{ Percentage of rock exclusive of foreign fragments } & \multirow{3}{*}{$\begin{array}{c}\begin{array}{c}\text { Percentage of } \\
\text { total rock }\end{array} \\
\text { Foreign rock } \\
\text { and mineral } \\
\text { fragments }\end{array}$} & \multirow{3}{*}{$\begin{array}{l}\text { Points } \\
\text { counted }\end{array}$} \\
\hline & & \multirow[b]{2}{*}{ Matrix $^{1}$} & \multirow{2}{*}{$\begin{array}{c}\text { Total } \\
\text { phenocrysts }^{2}\end{array}$} & \multicolumn{2}{|c|}{ Feldspar ${ }^{3}$} & \multicolumn{2}{|c|}{ Quartz } & \multicolumn{2}{|r|}{ Biotite } & & \\
\hline & & & & \multicolumn{6}{|c|}{ (percentage of phenocrysts) } & & \\
\hline H201Q & & 90 & 10 & 8 & $(80)$ & 1 & (10) & 1 & $(10)$ & 27 & 1,062 \\
\hline $\mathrm{P}$ & uv & 87 & 13 & 9 & (69) & 3 & (23) & 1 & (8) & 12 & 1,006 \\
\hline $\mathrm{O}$ & ud & 87 & 13 & 9 & (69) & 3 & (23) & 1 & (8) & 11 & 1,003 \\
\hline $\mathrm{N}$ & & 90 & 10 & 6 & $(60)$ & 2 & (20) & 2 & (20) & 1 & 1,007 \\
\hline $\mathrm{M}$ & vp & 90 & 10 & 6 & $(60)$ & 3 & $(30)$ & 1 & (10) & 4 & 1,044 \\
\hline $\mathbf{L}$ & & 92 & 8 & 4 & $(50)$ & 3 & (38) & 1 & (12) & 5 & 1,052 \\
\hline $\mathbf{J}$ & & 85 & 15 & 11 & (73) & 3 & (20) & 1 & (7) & 4 & 1,046 \\
\hline J-1 & & 92 & 8 & 6 & (75) & 1 & (13) & 1 & (11) & 4 & 987 \\
\hline I & ld & 91 & 9 & 7 & (78) & 1 & (11) & 1 & (11) & 7 & 956 \\
\hline $\mathrm{H}$ & & 89 & 11 & 9 & (82) & 1 & (9) & 1 & (9) & 6 & 1,064 \\
\hline $\mathrm{G}$ & & 91 & 9 & 6 & $(67)$ & 2 & (22) & 1 & (11) & 7 & 970 \\
\hline $\mathbf{F}$ & lv & 88 & 12 & 9 & $(75)$ & 2 & (18) & 1 & (9) & 4 & 971 \\
\hline $\mathrm{E}$ & & 87 & 13 & 10 & $(77)$ & 2 & (15) & 1 & (8) & 9 & 1,000 \\
\hline D & & 92 & 8 & 6 & (75) & 1 & (13) & 1 & (12) & 4 & 1,062 \\
\hline $\mathrm{C}$ & & 93 & 7 & 5 & (72) & 1 & (14) & 1 & (14) & 9 & 995 \\
\hline \multirow{2}{*}{\multicolumn{2}{|c|}{$\begin{array}{l}\text { Average - } \\
\text { Range }\end{array}$}} & 90 & 10 & 7 & $(71)$ & 2 & $(20)$ & 1 & $(10)$ & 8 & 1,015 \\
\hline & & $85-93$ & $7-15$ & & $4-11$ & & $1-3$ & & $1-2$ & $1-27$ & \\
\hline
\end{tabular}

${ }^{1}$ Includes pumice lapilli, average 8 percent.
${ }^{2}$ Not counted are traces of magnetite and very tiny crystal fragments of quartz, feldspar, and biotite. Includes phenocrysts in pumice lapilli and crystal fragments in matrix.

3Largely plagioclase, includes sanidine (trace to 1 percent of total rock), may include some foreign plagioclase.

4Mostly andesite of Little Table Mountain.

part of the vapor-phase zone (table 3). Minor-element contents of these samples are given in table 4.

The whole-rock analyses show that chemical differences between zones in the Holy Joe Member are very small. The most significant differences noted are that the vitrophyre has more water than the crystallized tuffs and that the oxidation state of iron in the crystallized tuffs is higher than in the vitrophyre. Both of these characteristics are common in ash-flow tuffs throughout the western United States and elsewhere.

The high water content of the vitrophyre, most likely the result of secondary hydration, causes problems in comparing the abundances of the nonvolatile constituents (Ross and Smith, 1955, p. 1086-1088). To more readily compare the nonvolatile elements, table 3 lists the analyses recalculated on a water-free basis; Barth cation amounts and C.I.P.W. norms are also listed. A comparison of the recalculated analyses shows a progressive but slight decline in silica and potassium upward in the section and increases in sodium and calcium. Without more data, however, it cannot be decided whether these differences are the result of progressive magmatic changes, transfer of elements during cooling or crystallization, solution during hydration, or simple coincidence.

The Holy Joe Member was made up of a series of very hot ash flows that erupted rapidly enough to cool as a unit. Dense welding, characteristic of hot ash flows, results in higher specific gravity than less welded flows. The rather uniform high specific gravity of this ash-flow sheet supports the evidence for dense welding in hand specimens and thin sections. ${ }^{2}$ The specific gravity of the Holy Joe Member (fig. 5) contrasts markedly with the specific gravity of the Aravaipa Member (see fig. 10). The concentration of vapor-phase crystallization in the central part of the cooling unit, instead of increasing upward as in most ash flows, probably means that overlying possibly hotter flows trapped gases in this part of the ash flow, which may have been slightly cooler and less welded than overlying and underlying flows.

Horizontal partings in ash-flow tuffs may define individual flow boundaries, partial cooling breaks, or zones of dense welding. To determine the presence of flow boundaries, studies should be made of density, porosity, chemical and modal composition, and size distribution of phenocrysts and lithic fragments, similar to studies made by Ratté and Steven (1967) and Lipman, Christiansen, and O'Connor (1966). Although a careful search for flow boundaries was not made, an extinct fumarole, formed by escaping gas before the next

${ }^{2}$ Microprobe analyses of titanomagnetite and ilmenite from two specimens of the Holy Joe Member (E. W. Hildreth, oral commun., 1979) are consistent with the interpretation, based on dense welding and specific gravity, of high emplacement temperature. Magmatic equilibration temperatures and $\log \mathrm{fO}_{2}$ values for the lower vitrophyre $(\mathrm{H} 201 \mathrm{C}$ and $\mathrm{H} 201 \mathrm{E}$ ) are $1035^{\circ}$ and $1065^{\circ} \mathrm{C}$ and -8.2 and -7.7 respectively. Temperatures of the upper vitrophyre could not be determined because of oxidation. The $\mathrm{T}^{\circ} \mathrm{C}$ and $\log f \mathrm{O}_{2}$ values were read graphically from the Buddington-Lindsley (1964) curves, using Hildreth's analyses as recalculated by the method of Carmichael (1967). These are exceptionally high magmatic temperatures for biotite quartz latites. Since both oxide phases are abundant, homogeneous, and unaltered, however, there is no obvious reason to doubt the data. Buddington and Lindsley (1964) suggested an accuracy of $\pm 30^{\circ} \mathrm{C}$, and $\pm 1 \log$ unit $f \mathrm{O}_{2}$; reproducibility for these specimens is far better. 

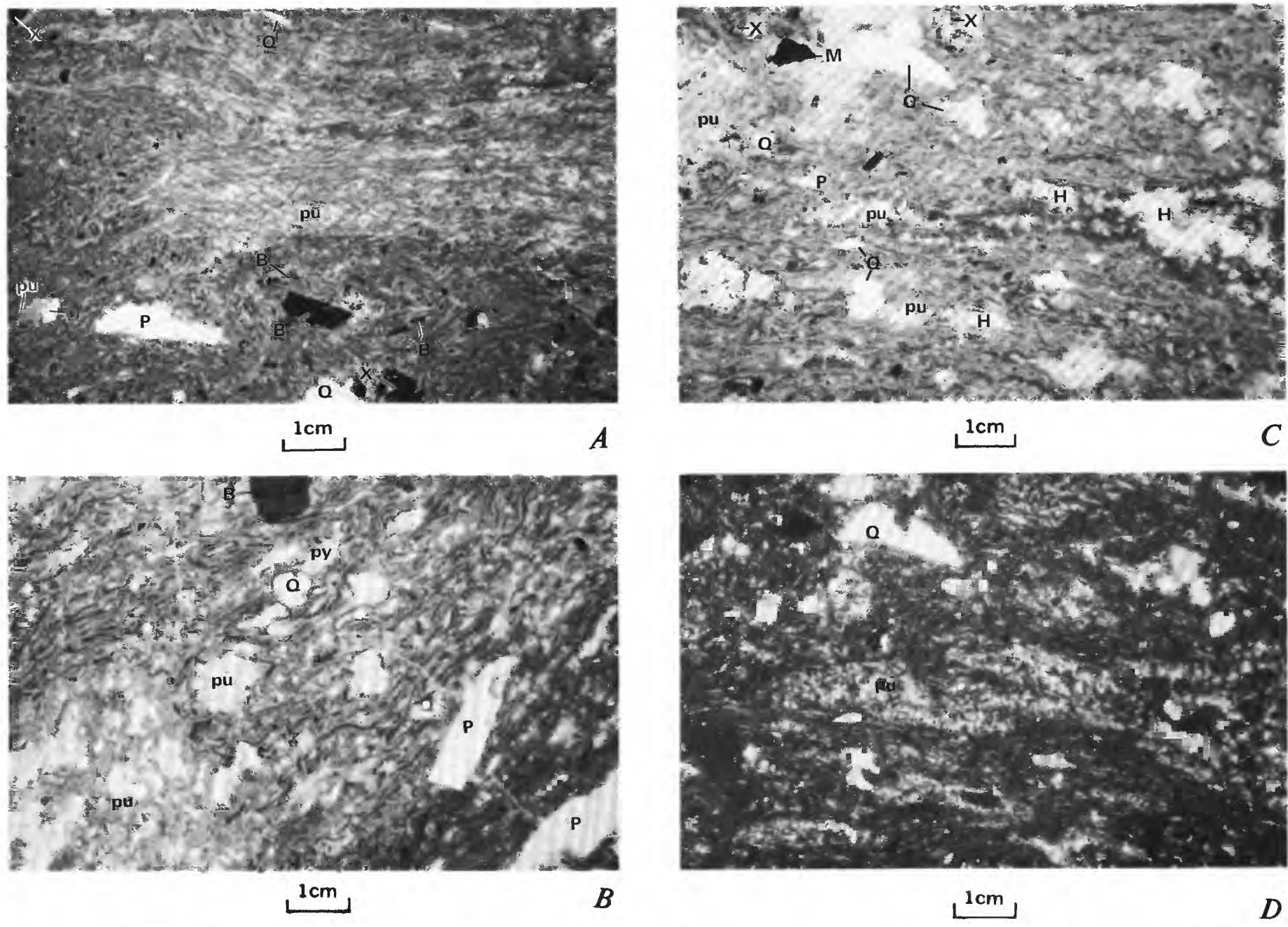

FIGURE 6.-Photomicrographs of Holy Joe Member. Biotite (B), holes (H), magnetite (M), plagioclase (P), pyroxene (py), pumice (pu), quartz (Q), xenolith or xenocryst (X). Plane polarized light, except as noted. A, Specimen H201G, lower densely welded vitrophyre. Pumice collapsed, but structure retained in frayed-out end at left. Shards have dark-orange center and lighter yellow margins; some larger ones have dull-brown centers, representing original character of glass. Perlitic cracks common. $B$, Densely welded devitrified rock (H201I). Shard structure well preserved as dark-brown streaks, with lighter margins that are finely devitrified. Pumice and some shard structure destroyed (light areas) by intergrowths of cristobalite and feldspar, some spherulitic intergrowths observed with crossed nicols. $C$, Dense welding in lower brown vapor-phase zone (H201J-1) evident in alinement of shards (dark streaks) and flattened pumice (horizontal light and dark area across middle of photograph). $D$, Same view as $C$, crossed nicols. Shows spherulitic intergrowths within pumice and its cavernous character (black areas labeled $\mathbf{H}$ in $C$ ). $E$, Dense welding in upper brown vapor-phase zone (H201M) and large flattened pumice lapilli. $F$, Same view as $E$, crossed nicols. Shows crystallization within pumice and its cavernous character. Shard matrix devitrified but mostly too fine grained to show in photograph. $G$, Dense welding in upper brown vapor-phase zone (H201N). Shard structure retained (dark streaks in dark areas). It and pumice structure destroyed by aggregates of feldspar and cristobalite (light areas). $H$, Same view as $G$, crossed nicols. Fine-grained devitrification barely visible in dark areas contrasts with coarser grained devitrification and vapor-phase crystallization of shards and pumice in light area. Note alteration of biotite. $I$, Dense welding in upper devitrified part of ash flow (H201O). Shards (dark streaks) molded against large phenocrysts and crystal fragments; pumice flattened. Spherulitic intergrowths of cristobalite and feldspar developed in pumice; apparent with crossed nicols. J, Densely welded upper vitrophyre (H201P), containing numerous small and large crystal and lithic fragments. Shard structure and flattened pumice structure preserved.

overlying flow was erupted, occurs in Oak Springs Canyon (fig. 2, loc. A). A short distance below the upper vitrophyre (between specimens $\mathrm{H} 201 \mathrm{O}$ and $\mathrm{P}$, see fig. 5 ) the boundary between two flows is marked by a concentration of lump pumice that was rafted on top of the underlying flow. This boundary is interpreted as representing the base of the last flow. Elsewhere, contrasts in abundance of crystal and lithic fragments and in the character of pumice fragments suggest different flows. Because there is no change in crystallization of the 

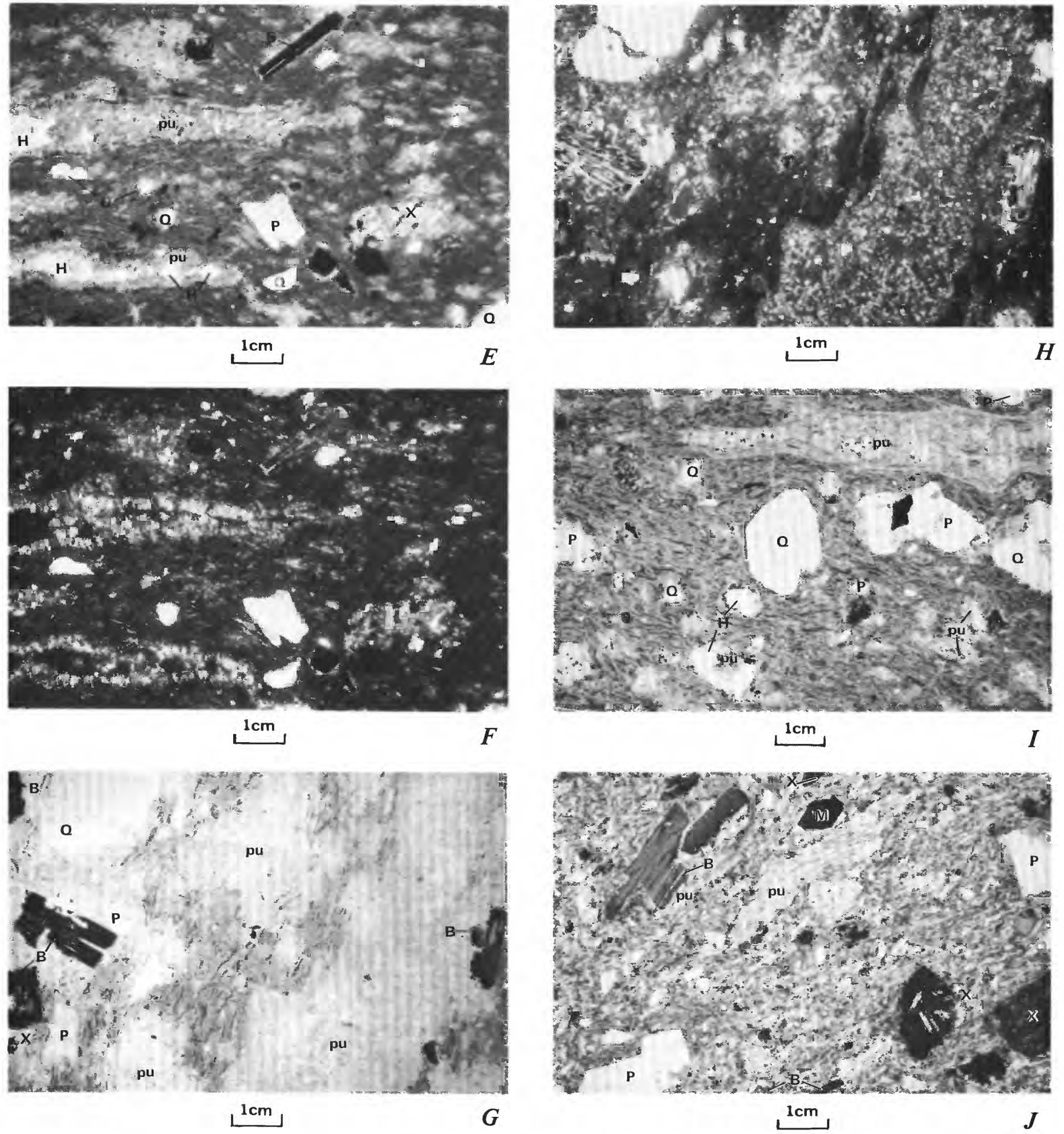

Figure 6.-Continued.

groundmass across the two recognized flow boundaries and the gradation from one zone of crystallization to another, the partings are not believed to define partial cooling breaks.
The vitrophyre at the top of the Holy Joe Member deserves special comment. Vitrophyres commonly occur near the base of cooling units; a second vitrophyre in a sequence of ash flows is generally interpreted as 


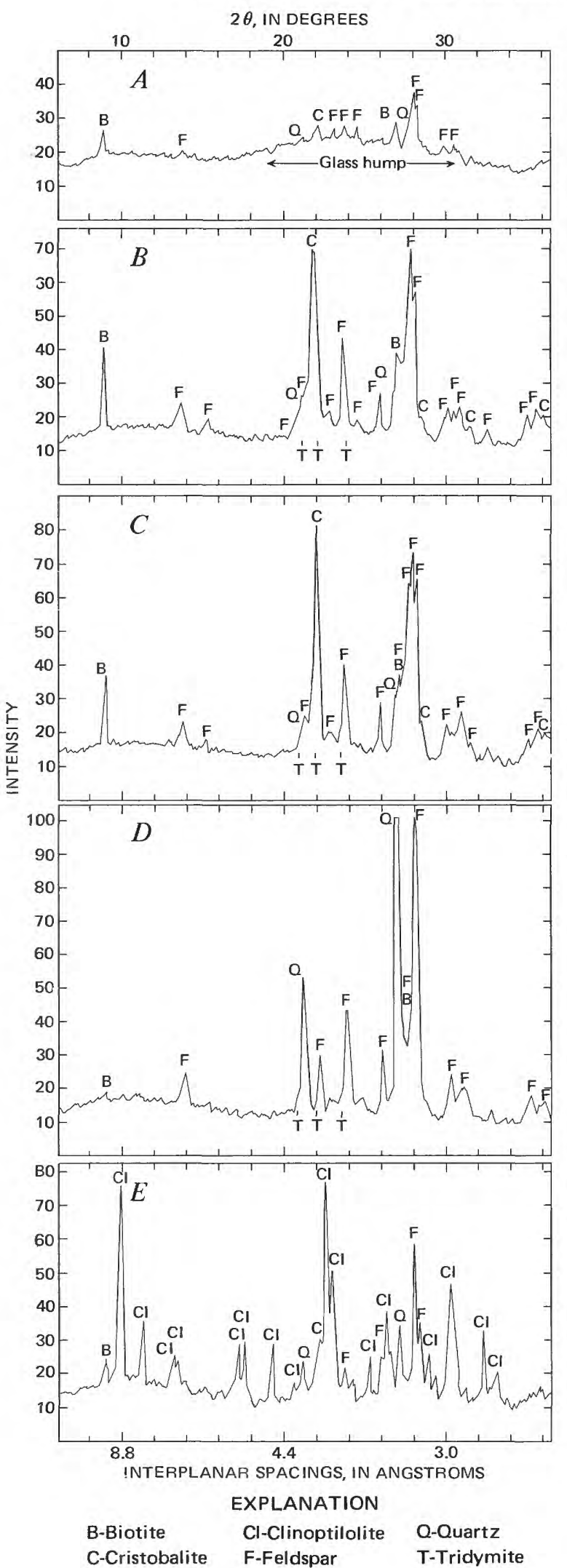

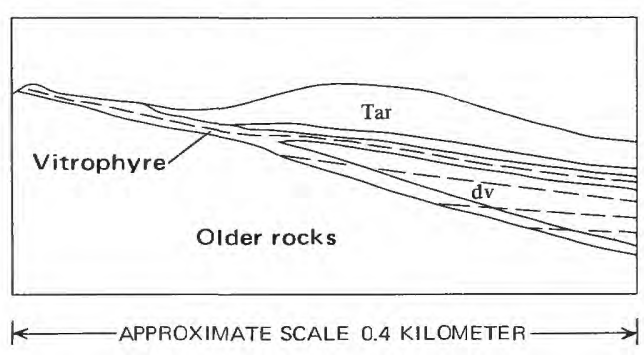

FIGURE 8.-Sketch showing effect of buried topography on zonation in Holy Joe Member. Lower and upper vitrophyres merge as ashflow sheet thins against prevolcanic topographic highs. Basal part of ash flow remains vitric and replaces devitrified and vapor-phase zones (dv). Dashed lines below and parallel to upper vitrophyre diagrammatically represent a few boundaries between individual flows. Aravaipa Member (Tar) and a thin basal tuff (not shown) overlie Holy Joe Member. Looking northwest across Oak Springs Canyon, from south of loc. 6 A, fig. 2.

indicating the base of an overlying cooling unit and a break in cooling history. The following evidence suggests that the upper vitrophyre does not represent a cooling break: the boundary marked by the lump pumice horizon, described above, is within the upper devitrified zone. No break in groundmass crystallization was recognized across this boundary. The devitrified material above the flow boundary grades upward into the upper vitrophyre. This last flow was hot enough to weld, but it cooled too rapidly, in contact with the air, to devitrify. Although a vitrophyre at the top of a cooling unit is rare, Lipman, Christiansen, and O'Connor (1966) have described a similar occurrence. I am indebted to R. L. Smith (oral commun., 1963) for first pointing out many of the features that led to the interpretation of this ash-flow sheet. Further evidence of a single cooling unit can be seen where the ash-flow sheet laps against prevolcanic topographic highs and the lower vitrophyre crosses flow lines until it merges with the upper vitrophyre (fig. 8).

FIGURE 7.-X-ray diffractographs of selected specimens of Holy Joe and Aravaipa Members, showing type of peak heights involved in estimation of composition. Calculated positions of major tridymite peaks also shown. Peak intensity (maximum) $=100$. $\mathrm{Cu} / \mathrm{Ni}$ radiation, $\lambda \mathrm{CuK} \alpha=1.5418 \mathrm{~A}$. Scan from $4^{\circ}$ to $36^{\circ}$ at $1^{\circ} 2 \theta$ /minute. $A$, Vitrophyre, H201E, Holy Joe Member. B, Devitrified zone, H201H, Holy Joe Member. $C$, Vapor-phase zone, H201M, Holy Joe Member. D, Vapor-phase zone, H202Q, Aravaipa Member. E, Zeolitized tuff, A3, Aravaipa Member. 
TABLE 3.-Chemical composition and comparison of glassy and crystallized parts, Holy Joe Member

[Major oxide analyses (weight percent) by P. Elmore, S. Botts, and C. Chloe by rapid methods described by Shapiro and Brannock (1962). See table 4 for minor-element analyses]

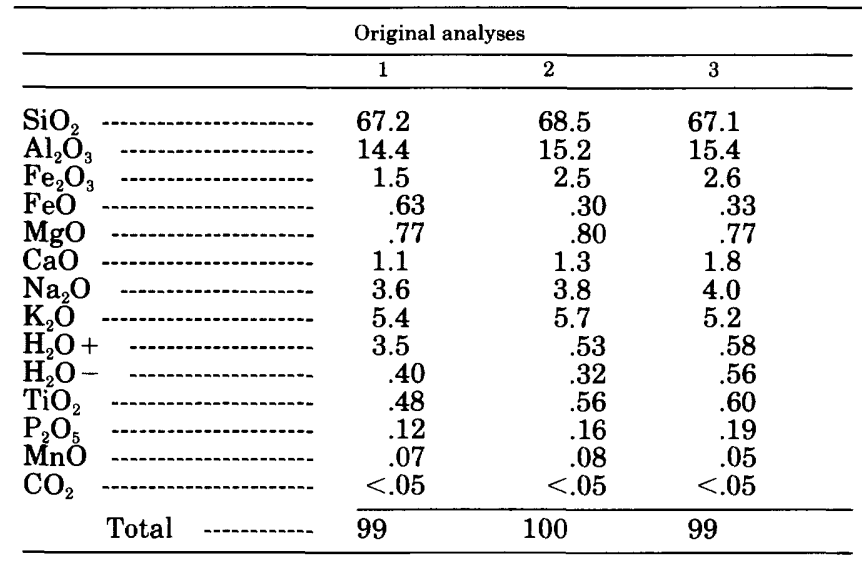

\begin{tabular}{|c|c|c|c|}
\hline \multicolumn{4}{|c|}{ CIPW norms } \\
\hline & 1 & 2 & 3 \\
\hline Quartz & 23.5 & 21.3 & 19.9 \\
\hline Orthoclase -..--..--.-.-. & 33.5 & 34.1 & 31.3 \\
\hline Albite & 32.0 & 32.5 & 34.5 \\
\hline Anorthite -...-..- & 4.9 & 5.5 & 7.8 \\
\hline Corundum -...-...-... & 1.0 & .8 & .4 \\
\hline Enstatite & 2.0 & 2.0 & 2.0 \\
\hline Magnetite & .9 & -- &.- \\
\hline Hematite & 1.0 & 2.5 & 2.7 \\
\hline Ilmenite & 1.0 & .8 & .8 \\
\hline Rutile & -- & .1 & .2 \\
\hline Apatite & .3 & .4 & .5 \\
\hline Total & 100.1 & 100.0 & 100.1 \\
\hline
\end{tabular}

\begin{tabular}{|c|c|c|c|c|}
\hline \multicolumn{5}{|c|}{ Recalculated without $\mathrm{H}_{2} \mathrm{O}$ and $\mathrm{CO}_{2}$} \\
\hline & & 1 & 2 & 3 \\
\hline \multirow{2}{*}{\multicolumn{2}{|c|}{$\begin{array}{l}\mathrm{SiO}_{2} \\
\mathrm{Al}_{2} \mathrm{O}_{3}\end{array}$}} & 70.5 & 69.3 & 68.4 \\
\hline & & 15.1 & 15.4 & 15.7 \\
\hline $\mathrm{Fe}_{2} \mathrm{O}_{3}$ & 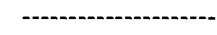 & 1.6 & 2.5 & 2.7 \\
\hline $\mathrm{FeO}$ & 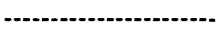 & .66 & .30 & .34 \\
\hline $\mathrm{MgO}$ & 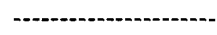 & .81 & .81 & .79 \\
\hline $\mathrm{CaO}$ & - & 1.1 & 1.3 & 1.8 \\
\hline $\mathrm{Na}_{2} \mathrm{O}$ & - & 3.8 & 3.8 & 4.1 \\
\hline $\mathrm{K}_{2} \mathrm{O}$ & - & 5.7 & 5.8 & 5.3 \\
\hline $\mathrm{TiO}_{2}$ & - & .50 & .57 & .61 \\
\hline $\mathrm{P}_{2} \mathrm{O}_{5}$ & - & .13 & .16 & .19 \\
\hline MnÖ & 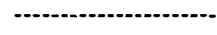 & .07 & .08 & .05 \\
\hline & -...-..-..- & 99.97 & 100.02 & 99.98 \\
\hline
\end{tabular}

\begin{tabular}{|c|c|c|c|}
\hline \multicolumn{4}{|c|}{ Barth cations } \\
\hline & 1 & 2 & 3 \\
\hline -................................. & 65.5 & 64.4 & 63.5 \\
\hline $\mathrm{Al}$ & 16.6 & 16.8 & 17.2 \\
\hline $\mathrm{Fe}+3$ & 1.1 & 1.8 & 1.9 \\
\hline $\mathrm{Fe}+2$ & .51 & .24 & .26 \\
\hline $\mathrm{Mg}$ & 1.1 & 1.1 & 1.1 \\
\hline $\mathrm{Ca}$ & 1.2 & 1.3 & 1.8 \\
\hline $\mathrm{Na}$ & 6.8 & 6.9 & 7.3 \\
\hline K & 6.7 & 6.8 & 6.3 \\
\hline $\mathrm{Ti}$ & .35 & .40 & .43 \\
\hline $\mathrm{P}$ & .10 & .13 & .15 \\
\hline Mn & .06 & .06 & .04 \\
\hline Total -........... & 99.22 & 99.93 & 99.98 \\
\hline Fe total & 1.61 & 2.04 & 2.16 \\
\hline $\mathrm{Fe}^{+2} / \mathrm{Fe}$ total & .32 & .12 & .12 \\
\hline
\end{tabular}

Note: Samples 1-3 from Oak Springs Canyon, NE corner sec. 6, T. 7 S., R. 18 E. (loc. A, fig. 2). 1, Lower vitrophyre, H201F, lab no. 159526. 2 , Lower devitrified zone, $\mathrm{H} 201 \mathrm{H}$, lab. no. 159527 . 3, Vapor-phase zone, H201K, lab no. 159528 .

\section{ARAVAIPA MEMBER}

The Aravaipa Member of the Galiuro Volcanics covers or underlies an area of more than $144 \mathrm{~km}^{2}$, from the northernmost latitude of Aravaipa Canyon (fig. 2) for about $11 \mathrm{~km}$ to the south side of Table Mountain (fig. 2), and from about $6 \mathrm{~km}$ west of to $6 \mathrm{~km}$ east of the boundary between the Holy Joe Peak and Klondyke quadrangles. The southernmost exposures on Table Mountain are about $75 \mathrm{~m}$ thick-and they show zoning typical of the central part of the ash-flow sheet. The absence of the member farther south, therefore, suggests its removal by erosion rather than thinning at a distal margin; this interpretation is further supported by the gentle north to northeast dip of the member and by its southward projection upward above the present land surface. The Aravaipa Member may, however, be present in some of the thick accumulations of ash flows to the southeast that have not yet been divided into separate units (Creasey and Krieger, 1978). To the east and probably to the southwest, the member has been downfaulted and buried by younger deposits. Its distal edge is exposed to the northwest. North of Aravaipa Canyon it is buried by younger members of the Galiuro Volcanics. Except at its distal margin, where it has been eroded, or where it thins, or is absent over topographic highs of older rocks, the member has a fairly uniform thickness of about $75 \mathrm{~m}$.

The Aravaipa Member is an ash-flow tuff of rhyolitic composition that has a well-developed interior zonation; this zonation indicates that it has an uninterrupted cooling history but it may be composed of two or more ash flows. Excellent exposures of the interior vertical zonation occur in near-vertical cliffs along Aravaipa Canyon (fig. 9) and along Oak Springs and up- 
TABLE 4.-Semiquantitative spectrographic analyses of minor elements in ash-flow tuffs and rhyolite-obsidian member, northern Galiuro Mountains, Ariz.

[Minor-element analyses by semiquantitative spectrographic methods by I. H. Barlow (nos. 1-8) and C. H. Heropoulos (nos. 9-13); values reported as the nearest in the series 1.5 , 2 , $3,5,7,10$. Comparison with quantitative analyses indicates that the same class interval is assigned in about 30 percent of the samples. $N$, not detected; leaders (--), not looked for; $<$, less than. Looked for but not found: $\mathrm{As}, \mathrm{Au}, \mathrm{Bi}, \mathrm{Cd}, \mathrm{Eu}, \mathrm{Ge}, \mathrm{He}, \mathrm{In}, \mathrm{Li}, \mathrm{Pd}, \mathrm{Pt}, \mathrm{Re}, \mathrm{Sb}, \mathrm{Sm}$, Ta, Te, Th, Ti, U, W]
, W

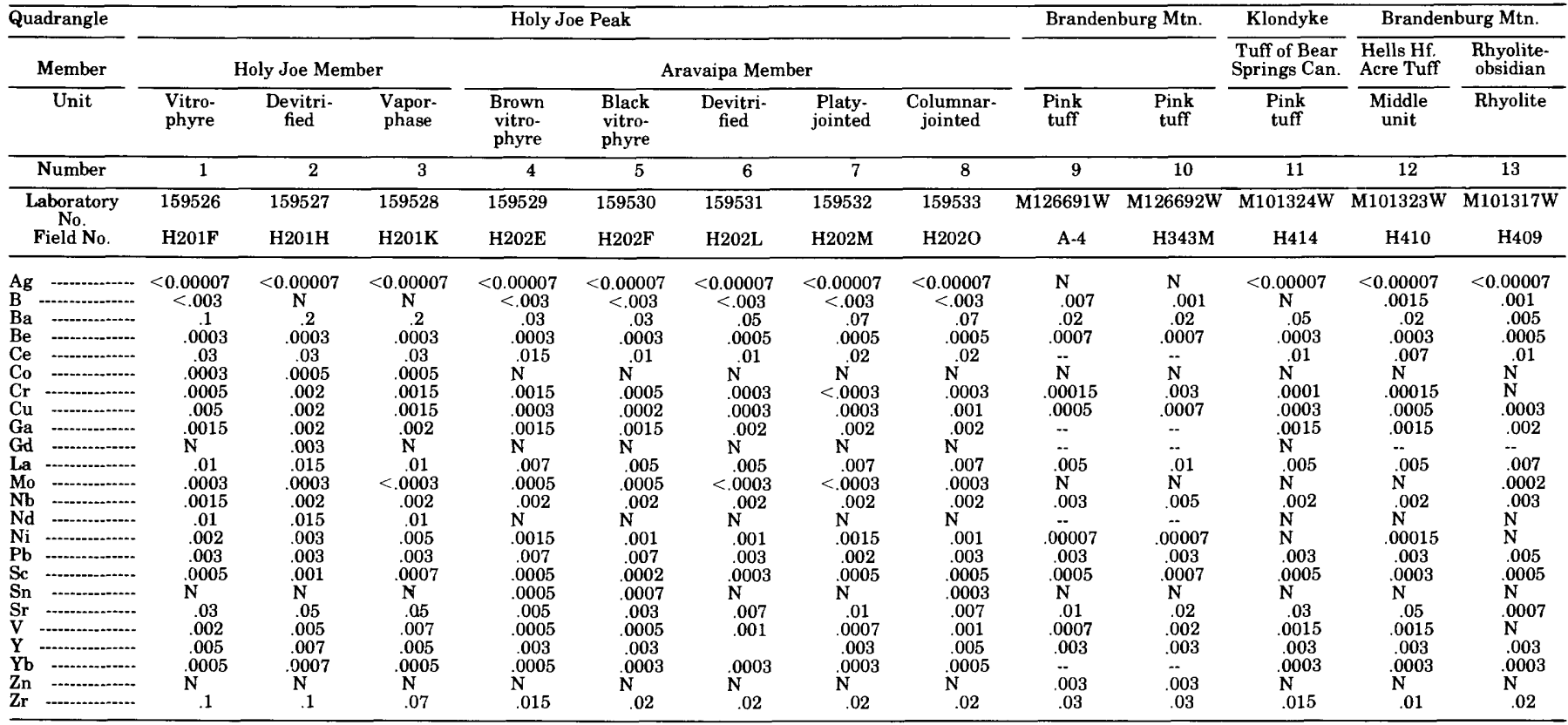

1-3. Oak Springs Canyon, NE corner sec. 6, T. 7 S., R. 18 E., loc. A. fig. 2.

4-5. East of Oak Springs Canyon, near center sec. 5, T. 7 S., R. 18 E., loc. $6 \mathrm{~A}$, fig. 2

6-8. Upper Bear Springs Canyon, center sec. 4, T. 7 S., R. 18 E., loc 6B, fig. 2 .

9. Between Whitewash and Bear Springs Canyons, NW $1 / 4$ sec. 30, T. 6 S., R. 18 E., loc. $2 \mathrm{~A}$, fig. 2.

10. Cave Canyon, W edge, N $1 / 2$ sec. 18, T. 6 S., R. 18 E., loc. 3 , fig 2.

11. West of Virgus Canyon, loc. 7, fig. 2 .

13. Aravaipa Canyon, east of Cave Canyon, loc. 8 , fig 2.

per Bear Springs Canyons. The ash flow can be separated into six lithologic zones, in ascending order, the lower nonwelded to partially welded tuff, densely welded vitrophyre, vuggy, platy-jointed, and columnar-jointed zones, and the upper partially welded white tuff. The lower tuff is pale orange, becoming very light brown at the top. The lower part of the vitrophyre is pale brown from oxidation; the rest of it is dark gray, except for brown spots at the top from incipient devitrification. The vuggy zone is light brownish gray except at the base, where it is pale brown. The platy-jointed zone is also light brownish gray. The columnar-jointed zone is slightly lighter in color. The upper white tuff grades from pinkish gray at the base to white at the top.

A suite of specimens, representing a vertical section across the ash flow, was collected in Oak Springs Canyon (specimens H202A-H) and upper Bear Springs Canyon (specimens H202I-R) (locations 6A and 6B, fig. 2). The approximate elevation of each specimen above the base of the ash flow, the field units or lithologic zones, color, zones of welding and crystallization, approximate mineralogic composition (based on X-ray diffractographs), and specific gravity of these specimens are summarized in figure 10.
The ash flow is composed of shards and pumice lapilli, phenocrysts of feldspar, quartz, and biotite, and foreign rock and crystal fragments. Phenocrysts average about 6 percent of the rock, and feldspars (plagioclase and sanidine) make up about 62 percent of the phenocrysts (table 5). Most of the lithic fragments are from older andesites, but in the upper part of the ash flow many of them are rhyolite, probably derived from earlier crystallization of the ash-flow magma.

Photomicrographs (fig. 11) of selected thin sections of the suite of specimens show the microscopic features of the ash-flow sheet. The lower tuff is completely nonwelded (fig. 11A) and vitric, except for the basal few meters, which has been altered to clinoptilolite (see composition column, fig. 10). The vitrophyre (fig. 11B) is densely welded and completely glassy, except for phenocrysts and xenoliths. Oxidation was considered the cause of the brown spots in specimens from the top of the vitrophyre (fig. $11 C$ ). However, they probably are due largely to incipient devitrification, as seen through crossed nicols (fig. 11D). The lighter areas, in contrast, are largely vitric. Where the ash flow filled a channel in older rocks, rapid chilling of the tuff against the channel walls caused the vitrophyre to reflect the underlying topographic irregularities (fig. 12). 
The vuggy zone (fig. 9) consists of densely welded and devitrified rock that is composed largely of cristobalite and feldspar, some of it in spherulitic intergrowths (fig. 11E). Biotite is altered, as it is in all crystallized parts of the ash flow; it is fresh only in vitric and zeolitized parts. The vuggy zone contains abundant large (as much as $10 \mathrm{~cm}$ in diameter), somewhat flattened vugs or lithophysae. The cavities are lined with inward-projecting acicular quartz crystals; locally centers contain calcite crystals. The abundance and size of the lithophysae (fig. 13) suggest that this ash flow had retained an uncommonly large proportion of volatiles in solution in the glass (Ross and Smith, 1961, p. 38). The volatiles were released after dense welding and during devitrification. Quartz and calcite were deposited in the vugs after the ash flow had partly crystallized and cooled. Thunder eggs (fig. 14), a distinctive type of lithophysae, formed along the contact between the vitrophyre and devitrified zone near Oak Springs Canyon (loc. 6A, fig. 2). They have a maximum diameter of $15 \mathrm{~cm}$. Gases released during devitrification accumulated within the spheres and produced sufficient pressure to fracture them. Small brown crystals of andradite garnet (identified by X-ray diffraction) occur within some of the voids (fig. 14G) and locally formed larger masses. To my knowledge, andradite has not been reported from rhyolite ash-flow tuffs; possibly it represents metamorphosed calcareous xenoliths.

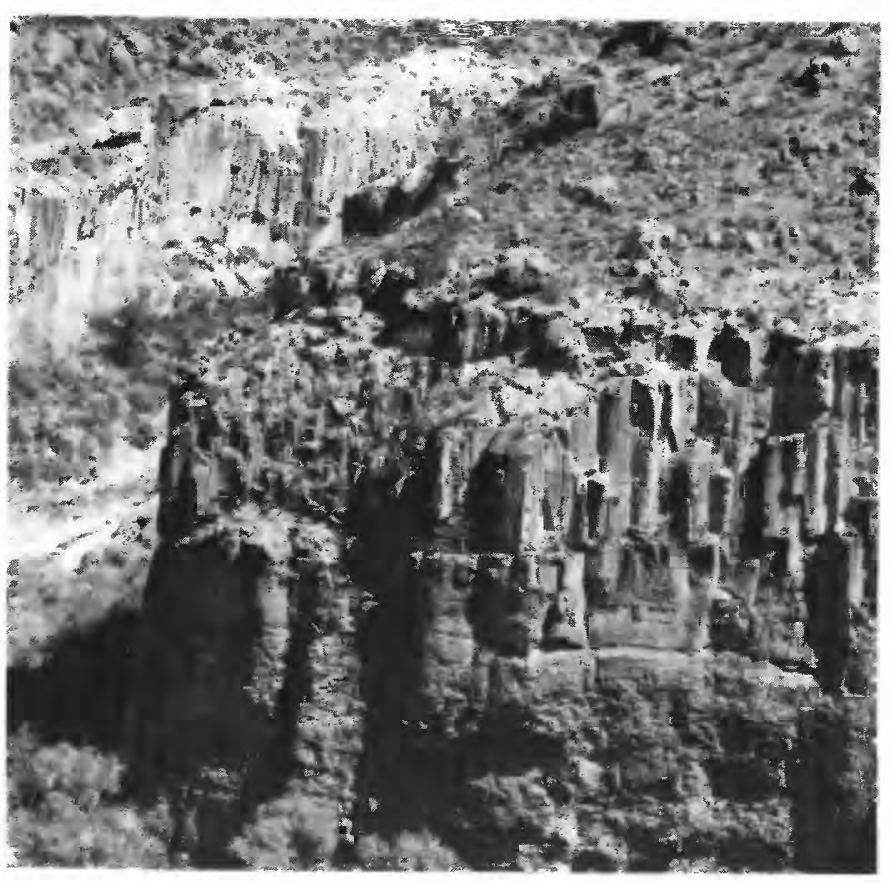

The platy-jointed zone is similar to the vuggy zone, except for closely spaced subhorizontal joints (fig. 15), a slightly lighter color, and fewer or no vugs. It is densely welded and completely devitrified (figs. $11 F$, $G$ ), with some coarse-grained devitrification products not only in pumice, but in some of the finer grained shard areas. Platy joints commonly develop near the zone of maximum compaction. A second thin slightly vuggy zone overlain by a thin platy-jointed zone was observed in many places, especially along Aravaipa Canyon. It was not studied in detail or traced so its significance is not understood. Its presence suggests the possibility of a second pulse of the ash flow.

The columnar-jointed zone (figs. 9, 15, see also fig. 25) is a cliff-forming light-brownish-gray devitrified rock, much of which is also quite densely welded. Coarse-grained vapor-phase crystallization is mainly confined to pumice lapilli (fig. $11 \mathrm{H}$ ). The columnar joints are contraction joints that develop during cooling; they are common in densely welded parts of ash flows and are also common in some vapor-phase zones.

Welding, crystallization, composition based on X-ray diffractographs, and specific gravity of the lithologic units of the central part of the ash flow will be included with the discussion of the distal margin of the ash flow.

The upper white tuff (fig. 9; see also fig. 27) is a soft,

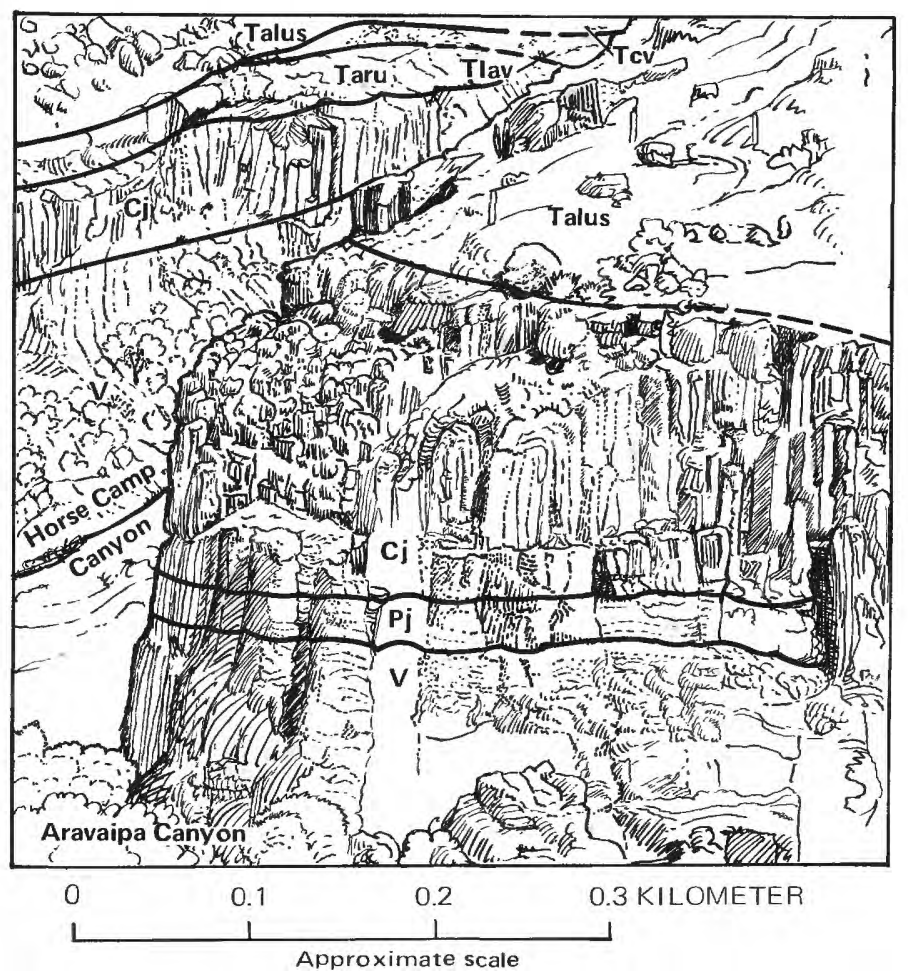

FIGURE 9.-Typical exposure of Aravaipa Member (Tar) on north side of Aravaipa Canyon showing normal vertical zonation (see sketch): vuggy (V), platy-jointed ( $\mathrm{Pj})$, and columnar-jointed $(\mathrm{Cj})$ zones, overlain, across Horse Camp Canyon, by upper white tuff (Taru). Vitrophyre below level of creek. Lower andesite (Tlav) and conglomerate (Tcv) of Virgus Canyon overlie upper white tuff at top center. 


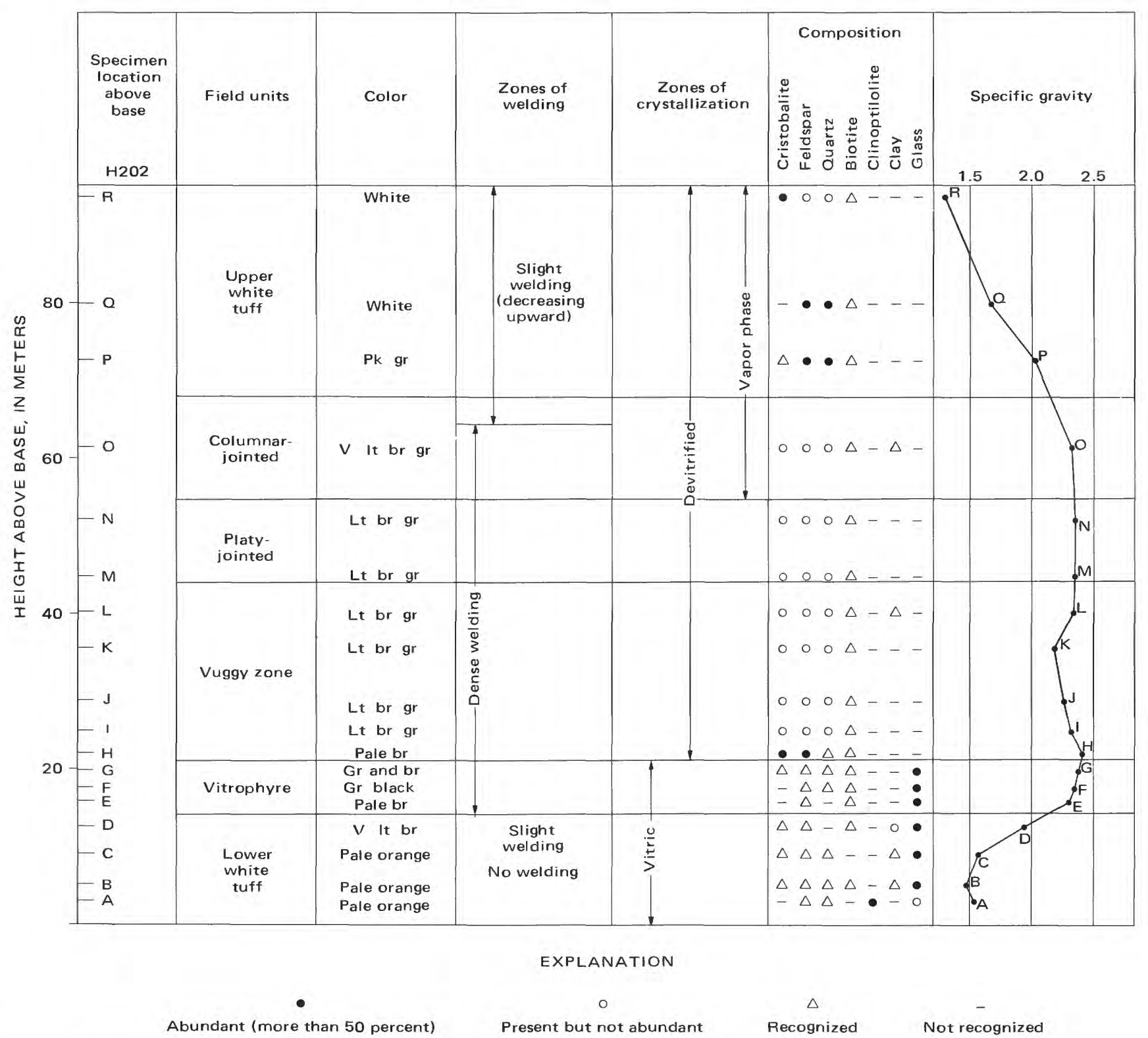

FigURE 10.-Some physical characteristics of interior parts of Aravaipa Member based on specimens collected at locality 6A(H202A$\mathrm{H}$ ) and 6B (H202I-R), figure 2. Modal data in table 5, chemical analyses of some specimens in table 6. Color terms: br, brown or brownish; gr, gray or grayish; lt, light; pk, pinkish; v, very. Abundance of minerals estimated from X-ray diffractographs of bulk samples. In addition to listed minerals, sample $\mathrm{H} 202 \mathrm{O}$ contained tridymite.

slope-forming, slightly welded unit that was referred to in the quadrangle reports as the upper nonwelded zone (Krieger, 1968a, b) and the white tuff unit (Simons, 1964). It is shown separately on the quadrangle maps, but not in figure 2 of this report. It is welded (figs. 11I, $J$ ), but welding decreases rapidly upward as shown by hand specimens and thin sections. Little welding has occurred at the very top (figs. $11 K, L$ ). The rock is devitrified, with some coarse-grained crystallization in pumice lapilli. The nonwelded vitric top was largely eroded before deposition of younger rocks. The tuff, in places, is pockmarked by wind erosion, a characteristic feature of vapor-phase zones in ash-flow sheets, according to Ross and Smith (1961, p. 30). A low cliff occurs at the top of the white tuff in many of the southern exposures. The induration is due to silicification and represents exposure for a long period of time before deposition of younger rocks. The cliff was not observed along Aravaipa Canyon, where the tuff probably was exposed to erosion and weathering for a 
TABLE 5.-Modes of Aravaipa Member

[Modes in volume percent. Based on thin-section studies of specimens H202A-H, loc. 6A, and H202I-R, loc. 6B (fig. 2). See figure 10 for lithologic zones and other characteristics. Field units: ut, upper tuff; cj, columnar jointed; pj, platy jointed; vug, vuggy; vit, vitrophyre; lt, lower tuff. $\mathrm{T}=$ trace]

\begin{tabular}{|c|c|c|c|c|c|c|c|c|}
\hline \multirow[b]{2}{*}{$\begin{array}{l}\text { Field } \\
\text { No. }\end{array}$} & \multirow[b]{2}{*}{$\begin{array}{c}\text { Field } \\
\text { unit }\end{array}$} & \multicolumn{5}{|c|}{ Percentage of rock exclusive of foreign fragments } & \multirow{2}{*}{$\begin{array}{c}\begin{array}{c}\text { Percentage of } \\
\text { total rock }\end{array} \\
\text { Foreign rock } \\
\text { and mineral } \\
\text { fragments }\end{array}$} & \multirow[b]{2}{*}{$\begin{array}{l}\text { Points } \\
\text { counted }\end{array}$} \\
\hline & & Matrix $^{1}$ & $\begin{array}{c}\text { Total } \\
\text { phenocrysts } 2\end{array}$ & Feldspar $^{3}$ & $\frac{\text { Quartz }}{\text { age of phenos }}$ & Biotite & & \\
\hline H202R & & 95 & 5 & $3(60)$ & $1(20)$ & $1(20)$ & 1 & 1,011 \\
\hline H202Q & ut & 96 & 4 & $2(50)$ & $2(50)$ & $\mathrm{T} \quad-$ & 2 & 1,025 \\
\hline $\mathrm{H} 202 \mathrm{P}$ & & 95 & 5 & $2(40)$ & $3(60)$ & $\mathrm{T} \quad--$ & $\mathrm{T}$ & 1,005 \\
\hline $\mathrm{H} 202 \mathrm{O}$ & cj & 94 & 6 & $5(83)$ & 1 (17) & $\mathrm{T} \quad--$ & $\mathrm{T}$ & 1,001 \\
\hline $\mathrm{H} 202 \mathrm{~N}$ & & 91 & 9 & $7(78)$ & 1 (11) & $1(11)$ & $\mathrm{T}$ & 1,004 \\
\hline H202M & pj & 86 & 14 & $9 \quad(64)$ & $4 \quad(28)$ & 1 (8) & $\mathrm{T}$ & 1,007 \\
\hline H202K & $\mathbf{P J}$ & 94 & 6 & $4(67)$ & 2 (33) & $\mathrm{T} \quad-$ & $\mathrm{T}$ & 1,002 \\
\hline H202I & vug & 93 & 7 & $5 \quad(71)$ & $1 \quad(15$ & 1 (14) & $\mathrm{T}$ & 1,003 \\
\hline $\mathrm{H} 202 \mathrm{H}$ & & 96 & 4 & $2(50)$ & 1 (25) & 1 (25) & $\mathrm{T}$ & 1,003 \\
\hline $\mathrm{H} 202 \mathrm{~F}$ & vit & 96 & 4 & 3 (75) & 1 (25) & $\mathrm{T} \quad-$ & $\mathrm{T}$ & 1,019 \\
\hline H202E & & 97 & 3 & $2(67)$ & 1 (33) & $\mathrm{T} \quad--$ & $\mathrm{T}$ & 1,005 \\
\hline H202D & It & 99 & 1 & $\mathrm{~T} \quad(40)$ & $\mathrm{T}(30)$ & $\mathrm{T}(30)$ & $\mathrm{T}$ & 1,010 \\
\hline & & 94 & 6 & $4(62)$ & $2(29)$ & $\mathrm{T} \quad(9)$ & $\mathrm{T}$ & 1,008 \\
\hline & & $86-99$ & $1-14$ & T-9 - & $\mathrm{T}-4-$ & $\mathrm{T}-1$ & $\mathrm{~T}-2$ & -.. \\
\hline
\end{tabular}

${ }^{1}$ Includes pumice lapilli; H202D has more pore space than overlying specimens.

2Not counted are traces of magnetite and very tiny crystal fragments. Includes phenocrysts in pumice lapilli and crystal fragments in matrix.

3Largely plagioclase, includes sanidine (trace to 2 percent of total rock); may include some foreign plagioclase.

${ }^{4}$ Older volcanic rock, mostly andesite, except for rhyolite in H202P-R.

shorter time. Because a zone of "solidly welded" tuff (Simons, 1964, p. 84-85) occurs at the top of the unit west of Parsons Canyon (east-central part of fig. 2, north of latitude $\left.32^{\circ} 52^{\prime} 30^{\prime \prime}\right)$, Simons concluded that the white tuff was not part of his upper welded unit. However, I found no evidence of a break in crystallization across the contact in this area. I interpret this densely welded zone as representing an additional pulse that was hot enough so that it became more densely welded than the underlying part. Crystallization appears gradational, and there is no evidence of any vitric material at the base of this last flow. The contact between the columnar-jointed and white tuff zones wherever observed is completely gradational. Lithology, specific gravity, and degree of welding and crystallization support the conclusion that the upper white tuff is part of the same cooling unit as the underlying ash flow.

The vertical zonation described above is characteristic of the Aravaipa Member throughout most of the Holy Joe Peak and Klondyke quadrangles. In the northwestern part of the outcrop area, however, near the distal margin of the ash flow, a marked change in zonation occurs. A remarkable exposure (fig. 16) of the distal margin of the welded part of the ash flow occurs on the north side of lower Whitewash Canyon. The slightly welded, columnar-jointed vapor-phase zone thins rapidly and pinches out. Pink nonwelded tuff underlies, locally overlies, and extends beyond the welded part of the ash flow. This same change can be seen on the northwest side of Bear Springs Canyon, near a small canyon between Hells Half Acre and
Whitewash Canyons, and in Cave Canyon north of Aravaipa Canyon. Another view (fig. 17) shows the complete change from the stacked-up zonation typical of the interior of the ash flow at the right to the nonwelded distal margin, the view shown in figure 16 , at the extreme left. The nonwelded basal tuff becomes progressively thicker away from the interior and successively replaces the vitrophyre, the vuggy, and the platy-jointed zones. Similarly, the columnar-jointed zone increases in thickness but farther outward is entirely replaced by nonwelded tuff.

Detailed studies of the ash flow were made at selected localities from the interior toward the northwestern distal margin, and a suite of specimens was collected at each locality (fig. 18; also fig. 2). Figure 19 is a diagrammatic summary of the studies made; it illustrates the general distribution, both horizontally and vertically, of lithology, welding, crystallization, mineralogy, and specific gravity from the southeast (loc. 6A and $6 \mathrm{~B}$ ) to the northwest (loc. 1B). Because no specimens were collected from Whitewash Canyon north (loc. 1B), data from Bear Springs Canyon north (loc. 1A, 2A, 2B) have been used. Details from the east side of Cave Canyon (loc. 3) are also inserted between Whitewash Canyon north and south (loc. 1B and 4). This section is of interest because it is one of the few places where the nonwelded zeolitized top has been preserved and because the nonwelded basal tuff has been replaced by mordenite, instead of clinoptilolite, the zeolite that largely replaces nonwelded parts of the ash flow elsewhere. Details of the lithology and color, specific gravity, and mineralogy are shown in figures 

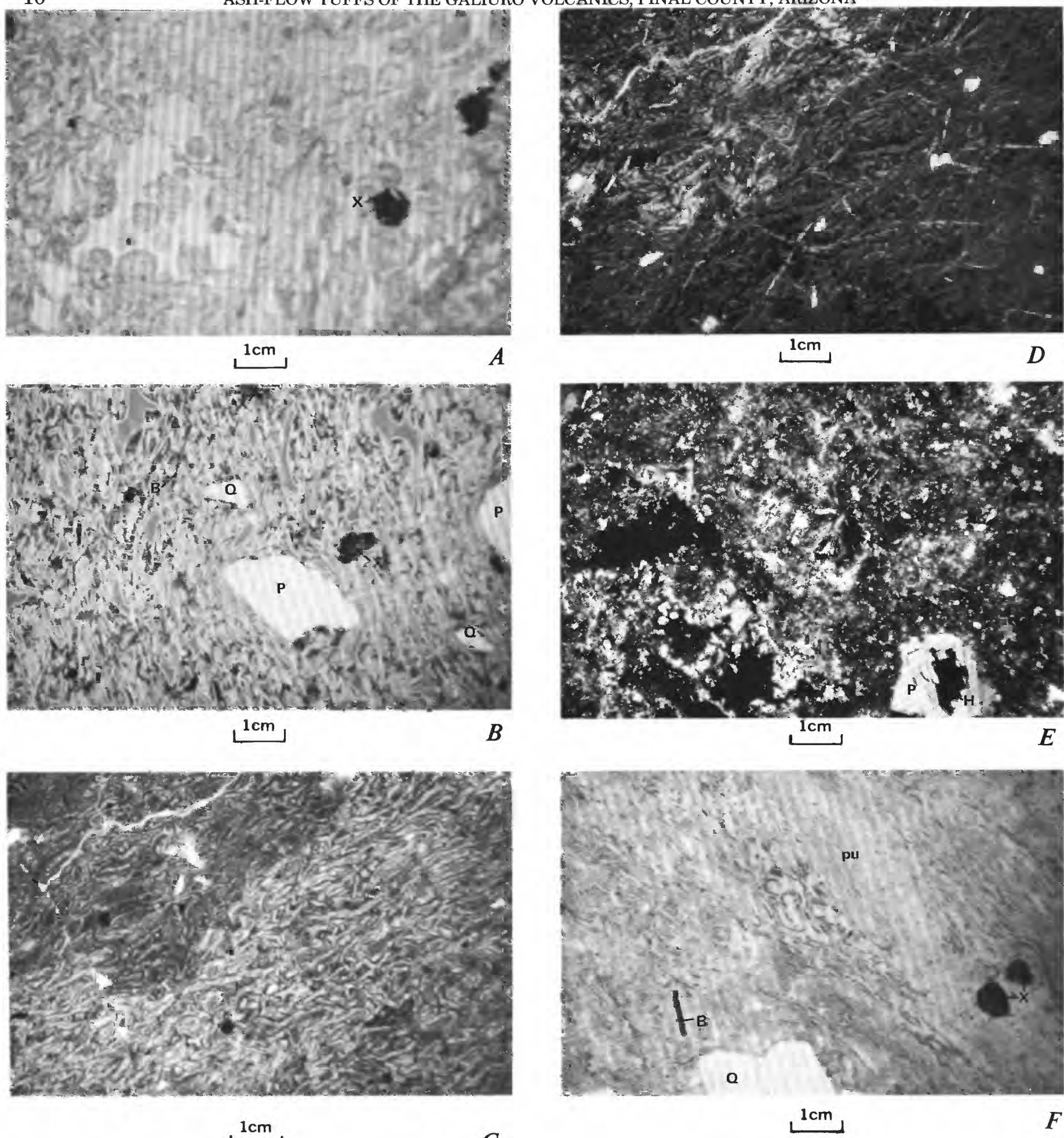

\section{$1 \mathrm{~cm}$}

C

FIGURE 11.-Photomicrographs of specimens from interior of Aravaipa Member. Biotite (B), magnetite (M), plagioclase (P), pumice (pu), quartz (Q), vug (V), xenolith or xenocryst (X). Plane polarized light, except as noted. A, Lower white tuff (H202B); completely nonwelded with undeformed shards and unbroken glass bubbles. B, Strongly welded vitrophyre (H202F). Shards molded against crystal fragments. Large shards have dull-brown centers, representing original character of glass, and colorless margins. Groundmass contains much fine dust. Other parts of thin section show flattened pumice lapilli. $C$, Densely welded vitrophyre (H202G) with well-preserved shard structure. Shows part of one brown spot (darker area) in lighter colored vitrophyre. $D$, Same view as $C$, crossed nicols. Shows that areas that were darker in plane polarized light are clearly devitrified. $E$, Welded tuff from vuggy zone (H202J), crossed nicols. Show spherulitic intergrowths of cristobalite and feldspar in pumice. Shard structure visible in plane light. Black areas (except in plagioclase) are vugs and are lined with quartz. F, Strongly welded, platy jointed tuff (H202N). Excellent preservation of shard structure, with dark streak down 

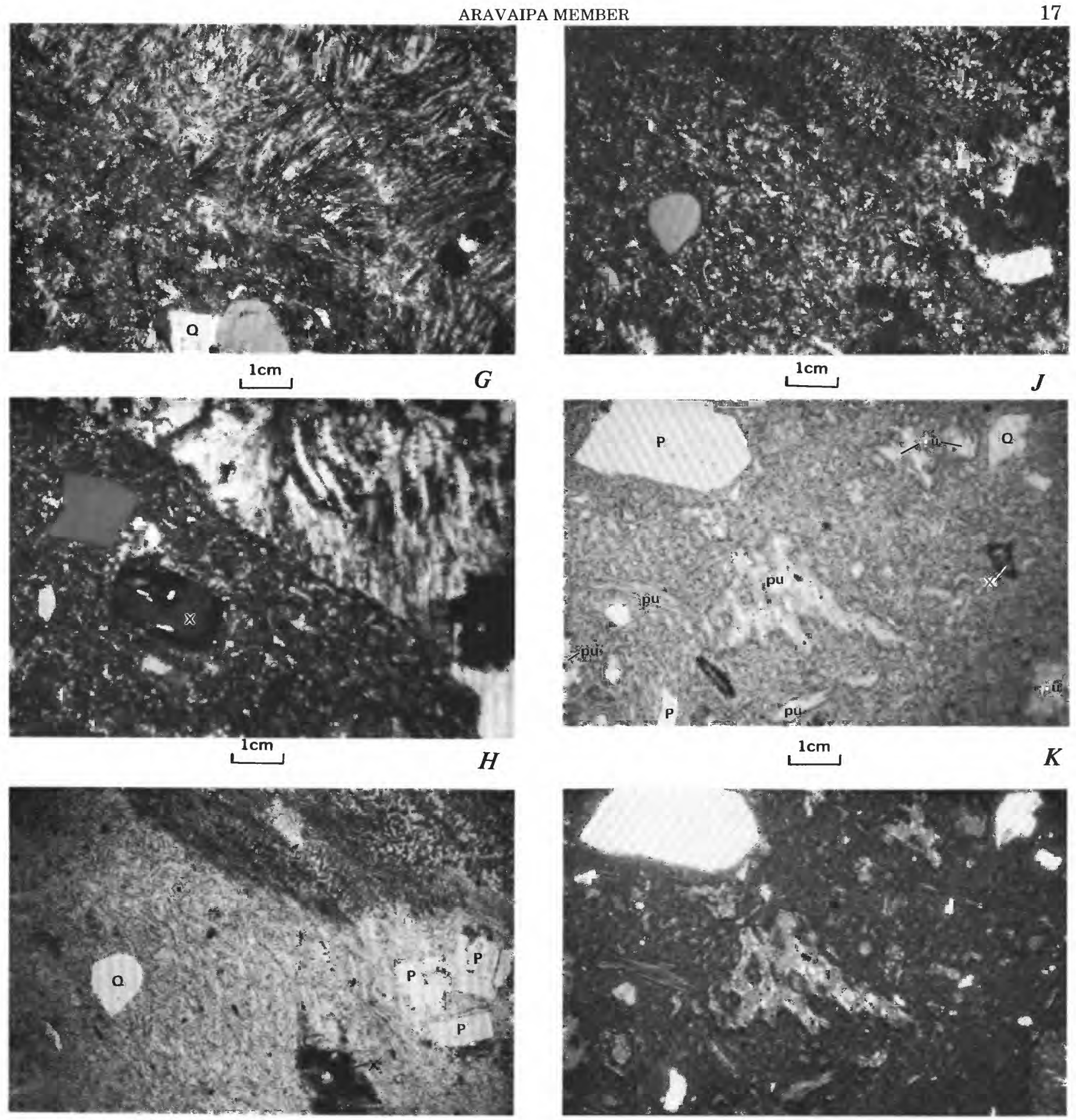

$1 \mathrm{~cm}$

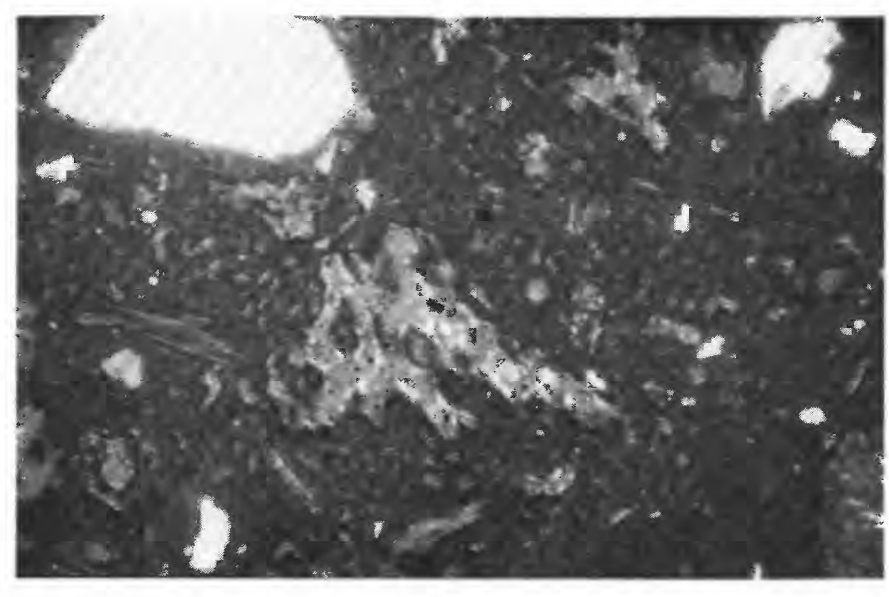

$1 \mathrm{~cm}$

centers of shards, tube structure visible in large flattened pumice lapillus. $G$, Same view as $E$, crossed nicols. Intergrowths of cristobalite and feldspar transect pumice and shard structure; intergrowths meet to form dark line through center of pumice lapillus. $H$, Columnarjointed vapor-phase zone (H202O), crossed nicols. Shows contrast in texture between shard (finer grained) and pumice (coarser grained) areas. Fine-grained devitrification products are cristobalite and feldspar, but coarse-grained vapor-phase products in pumice include small tridymite crystals (too small to recognize in picture). In plane light, shard structure can be recognized. I, Slightly welded upper white tuff (H202P), showing shard structure and part of large pumice lapillus. J, Same view as I, crossed nicols. Vapor-phase minerals, tridymite and cristobalite, converted to quartz (see fig. 10, composition column). K, Nearly nonwelded tuff (H202R) from near top of upper white tuff. Shard structure defined by very fine grained axiolitic intergrowths of cristobalite and feldspar; pumice structure partly destroyed by coarse-grained spherulitic intergrowths. $L$, Same view as $K$, crossed nicols. 

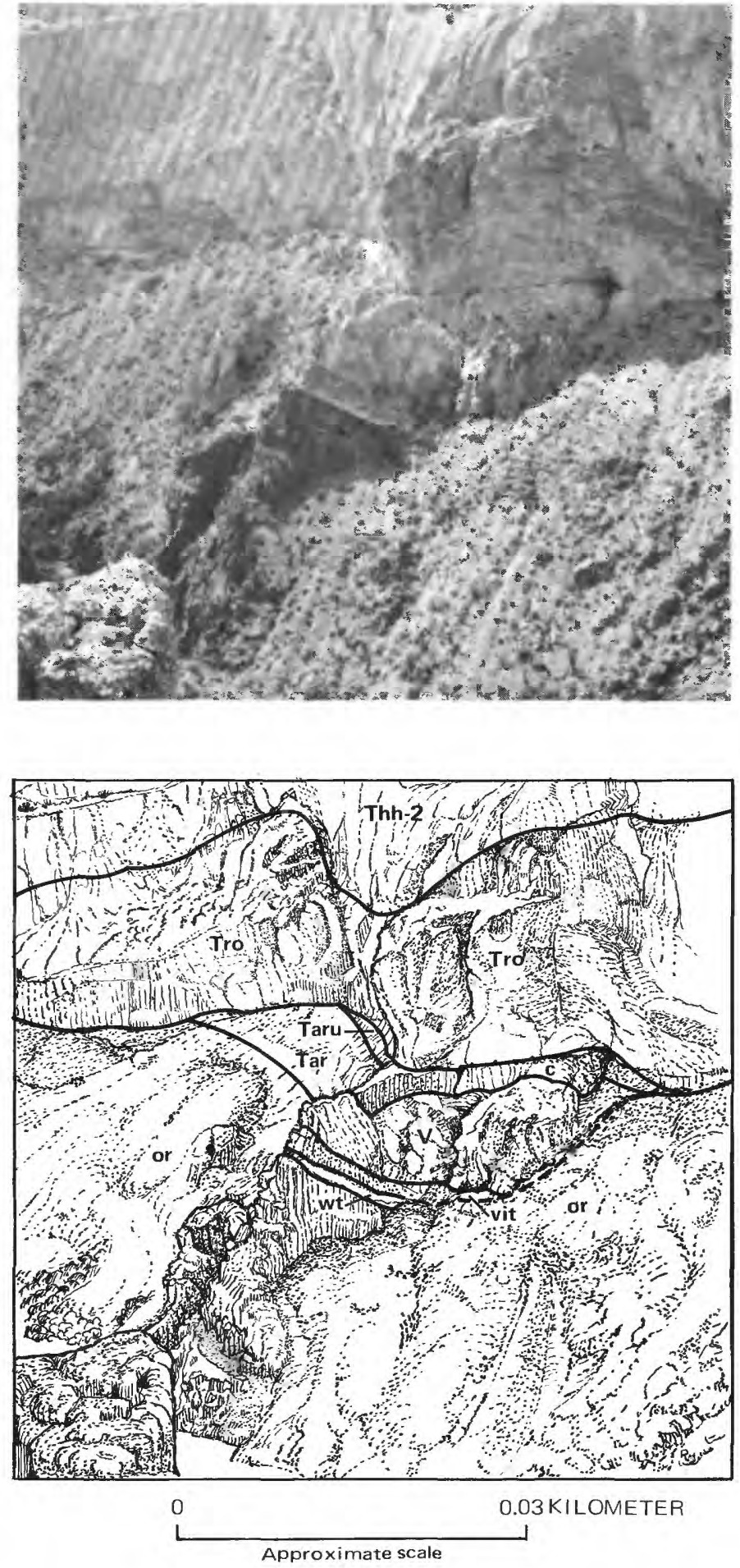

FIGURE 12.-Aravaipa Member filling channel in Precambrian rocks (or). Sketch shows stratigraphic relations. Basal white tuff (wt) and vitrophyre (vit) reflect underlying topographic irregularities. Vuggy zone (v) occupies central part of channel and is overlain by columnar-jointed zone (c). Also shown are undifferentiated Aravaipa Member (Tar) and upper tuff unit (Taru), rhyolite-obsidian member (Tro) and middle unit of Hells Half Acre Tuff Member (Thh-2). View north across Aravaipa Canyon from west of mouth of Virgus Canyon. Contact dashed where inferred.

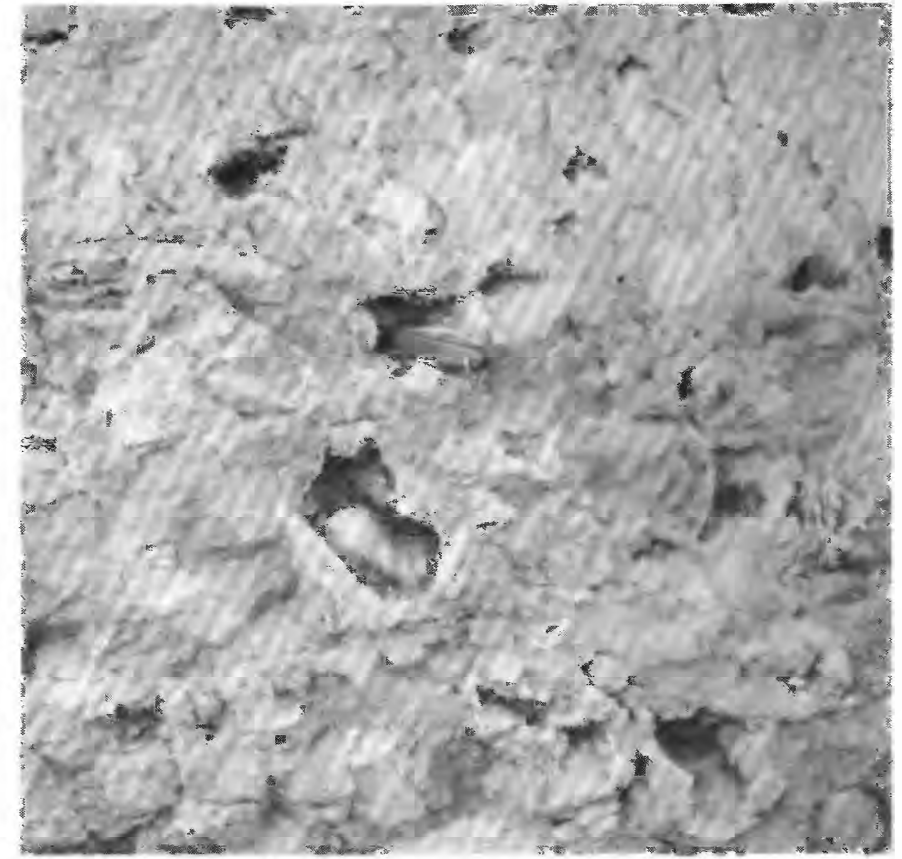

FiguRE 13.--Vuggy zone, Aravaipa Member showing quartz lining cavities. See pocket knife for scale. East of Oak Springs Canyon (loc. 6A, fig. 2).

20-22. Photomicrographs of selected thin sections (fig. 23) show the microscopic features.

The trends shown in figures 19-22 were caused by the decrease in temperature of the ash flow with distance from its source and by the rapid thinning of the ash flow against preexisting topographic highs (see fig. 2 where, west of Cave Canyon, Hells Half Acre Tuff Member overlaps Aravaipa Member onto the underlying andesite of Depression Canyon.)

At Bear Springs Canyon south (loc. 5) and Whitewash Canyon south (loc. 4), the lithologic zones (figs. $19 A, 20)$ are essentially the same as in the interior of the ash flow (loc. 6A, B), except that at Bear Springs Canyon south the vitrophyre extends to, or nearly to, the base of the ash flow, probably because of a topographic high, and at Whitewash Canyon south, pink tuff underlies the vitrophyre. The upper white tuff has been removed by erosion from location 4 . The specific gravities (figs. $19 E$ and 21 ) of the lithologic zones at locations 4 and 5 are similar to those at location 6 , except that in the upper part of the columnar-jointed zone at location 4, specific gravity is as low as it is in the upper part of the white tuff at locations 5 and 6 . Northwest of Whitewash Canyon south (loc. 4), only columnar-jointed tuff and pink tuff remain, and specific gravity (figs. $19 E$ and 21 ) decreases in both zones, reflecting in part a decrease in welding towards the dis- 

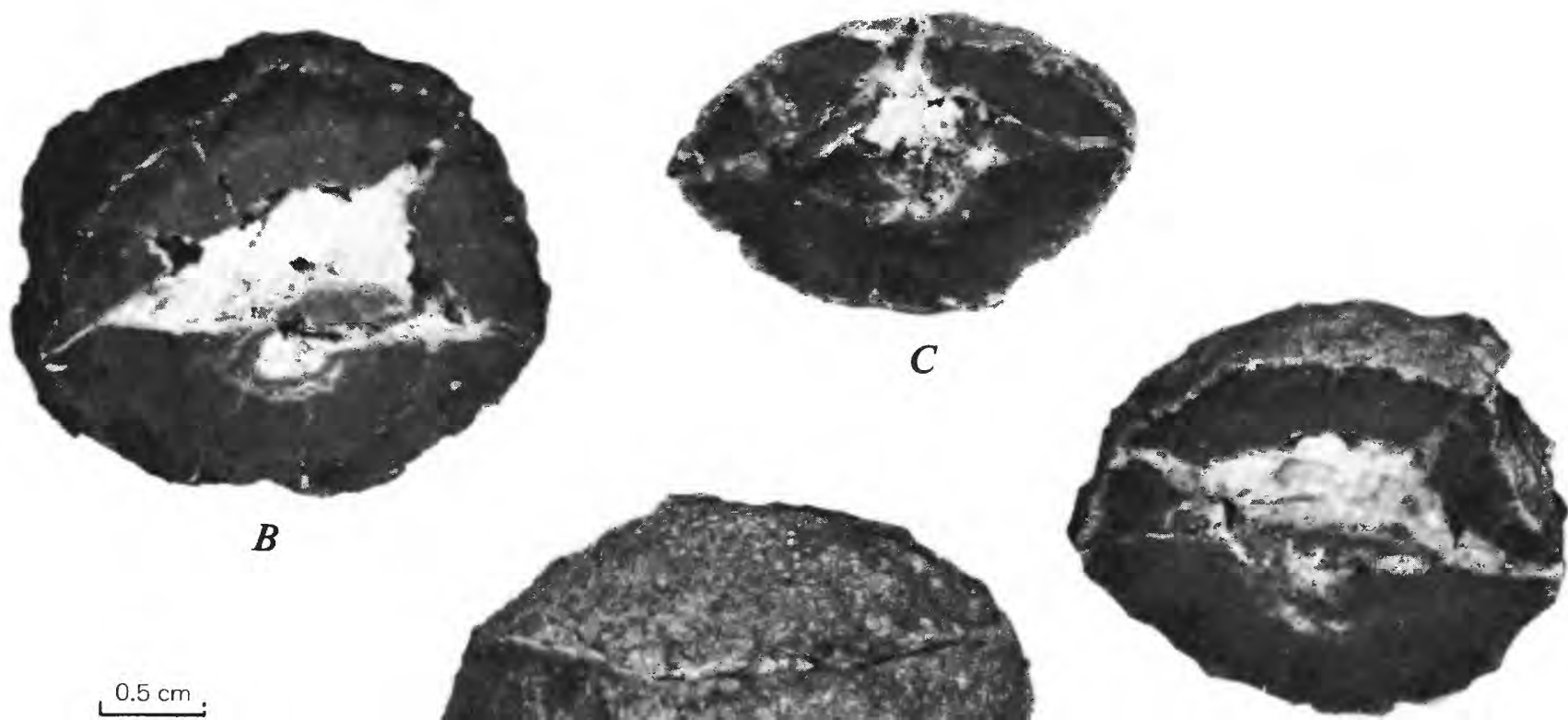

C

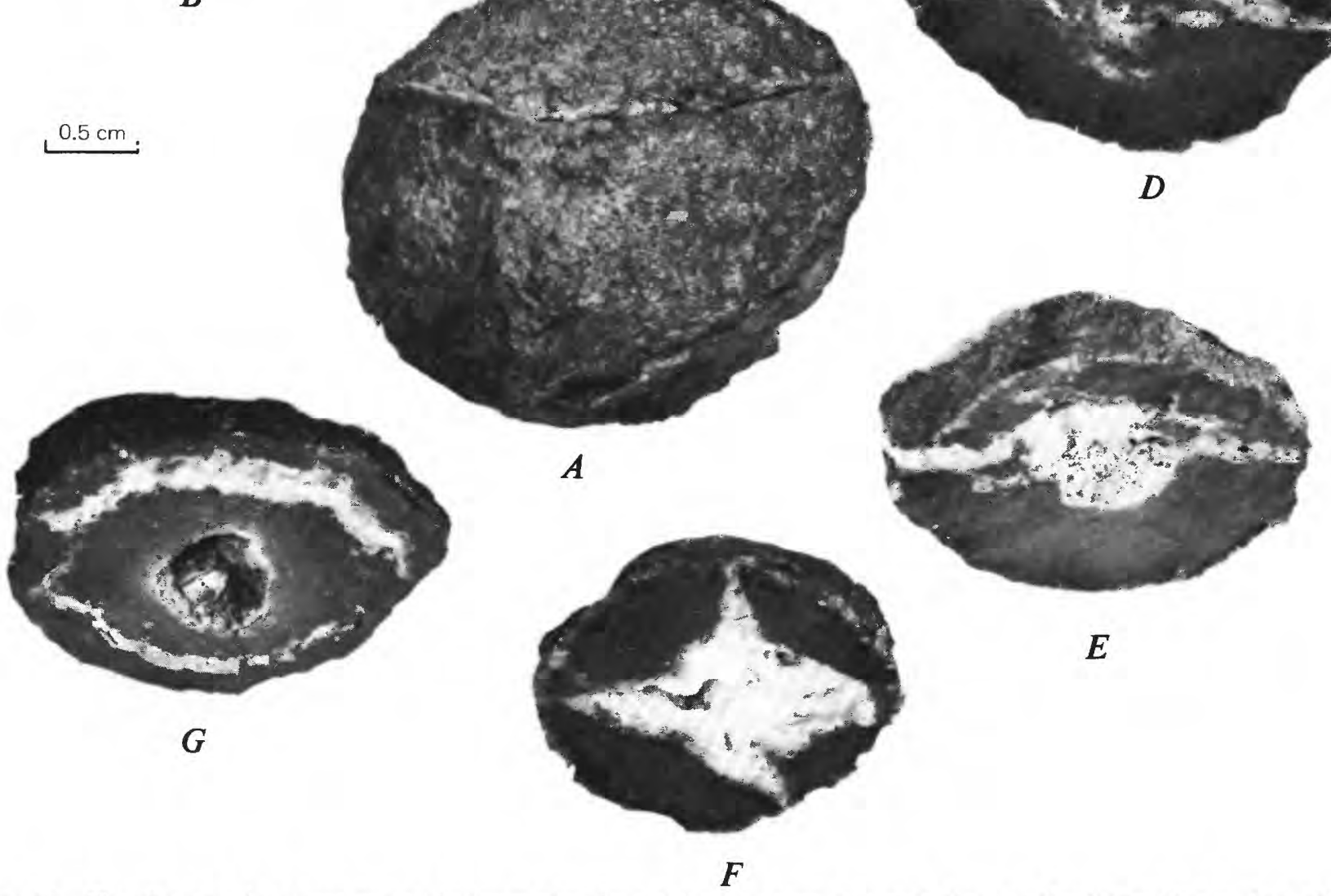

FIGURE 14.-Thunder eggs from near contact between vitrophyre and vuggy zone, Aravaipa Member. Cauliflowerlike surface (A) caused by spotty incipient devitrification. Upper surface of thunder egg, as originally oriented, is cut by fractures filled with chalcedony that form low ridges. Upper and lower halves are separated by a fracture, also filled with chalcedony. Fractures, typically three in number, in upper half generally do not extend into lower half. Incipient devitrification extends inward for about $0.5 \mathrm{~cm}$, inside of which ash-flow tuff is completely devitrified into spherulitic intergrowths of cristobalite and feldspar $(B-G)$. Vertical sections $(B-E)$ through typical thunder eggs show irregular, angular character of partly filled voids in which chalcedony was deposited, and concentration of chalcedony in upper part of voids (especially $D$ and $E$ ). Angular fragments of detrified tuff occur within voids $(B$ and $C$ ). Finer grained material in lower part of some voids $(C, D, E)$ consists of quartz, cristobalite, clay, and locally clinoptilolite. Variations in openings and fillings occur in some thunder eggs $(F$ and $G$ ). Small crystals of andradite garnet locally occur in or partly fill voids $(G)$.

tal margin. The tip of the columnar-jointed zone at location $1 \mathrm{~A}$ is nearly nonwelded (fig. $23 H$ ). Thin sections (figs. $23 A-G$ ) also show the complete absence of weld- ing in the pink tuff. Shards and glass bubbles are generally well preserved because of axiolitic replacement, regardless of whether the zeolite is clinoptilolite (figs. 


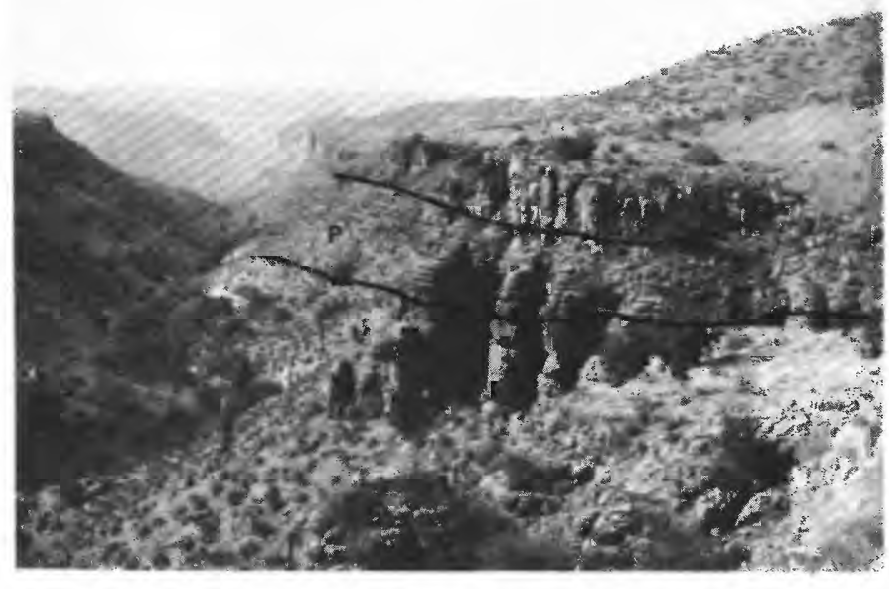

Figure 15.-Platy-jointed zone (P), between vuggy (V) and columnar-jointed (C) zones, Aravaipa Member, showing closely spaced subhorizontal joints. Exposed thickness of member, approximately $30 \mathrm{~m}$. North side of Bear Springs Canyon, location 5 (fig. 2).

$23 A-D$ ) or mordenite (figs. $23 E, F$ ). The specific gravity of the pink tuff may have been less than 1.5 before it was zeolitized; Hoover (1966) found that bulk densities of tuffs increase during zeolitization. The specific gravity of the pink tuff is low but somewhat variable, in part owing to variations in the number of lithophysae and pumice lapilli, which tend to decrease specific gravity.

Each of the specimens collected was X-rayed; the results are shown in figure 22 and summarized diagrammatically in figure $19 \mathrm{D}$. X-ray diffractographs of the ash flow show not only the phenocrysts (feldspar, quartz, and biotite) but also devitrification products (cristobalite and feldspar), secondary quartz, and alteration products (clay and zeolite). The problems related to determination of mineral composition by X-ray diffractographs have been discussed in the section on the Holy Joe Member (p. 5). X-ray diffractographs were very useful in studying the Aravaipa Member, especially the many specimens for which no thin sections were available and those that had been zeolitized. The X-ray patterns indicate that quartz, rather than cristobalite, is the principal silica mineral in the columnar-jointed zone at locations $2 \mathrm{~B}, 3,4$, and 5 , and in most of the upper white tuff at locations 5 and 6 (see fig. 7 for diffractograph of $\mathrm{H} 202 \mathrm{Q}$; this also shows that the principal tridymite peaks may have been masked by peaks of other minerals). At the distal margin of the columnar-jointed zone (locs. 1A, 2A) and in the top of the upper white tuff (locs. 5 and 6 ), cristobalite is the dominant silica mineral.

The common devitrification products developed during crystallization of a cooling ash flow are cristobalite and feldspar. They start growing at grain boundaries and meet at a central zone of discontinuity that forms a dark line (figs. $11 F, G$ ), producing the typical axiolitic texture that preserves the shard structure.

Vapor-phase crystallization is superimposed on devitrification and may obscure shard structure. Vaporphase crystals develop first in pumice lapilli, where they are coarser than devitrification products. Tridymite, together with cristobalite and feldspar, is a common vapor-phase mineral in all younger Tertiary and Quaternary ash-flow tuffs. Tridymite was recognized in thin sections of specimens from the vapor-phase zone (columnar-jointed zone and lower part of upper white tuff at loc. 6) but not from the columnar-jointed zone

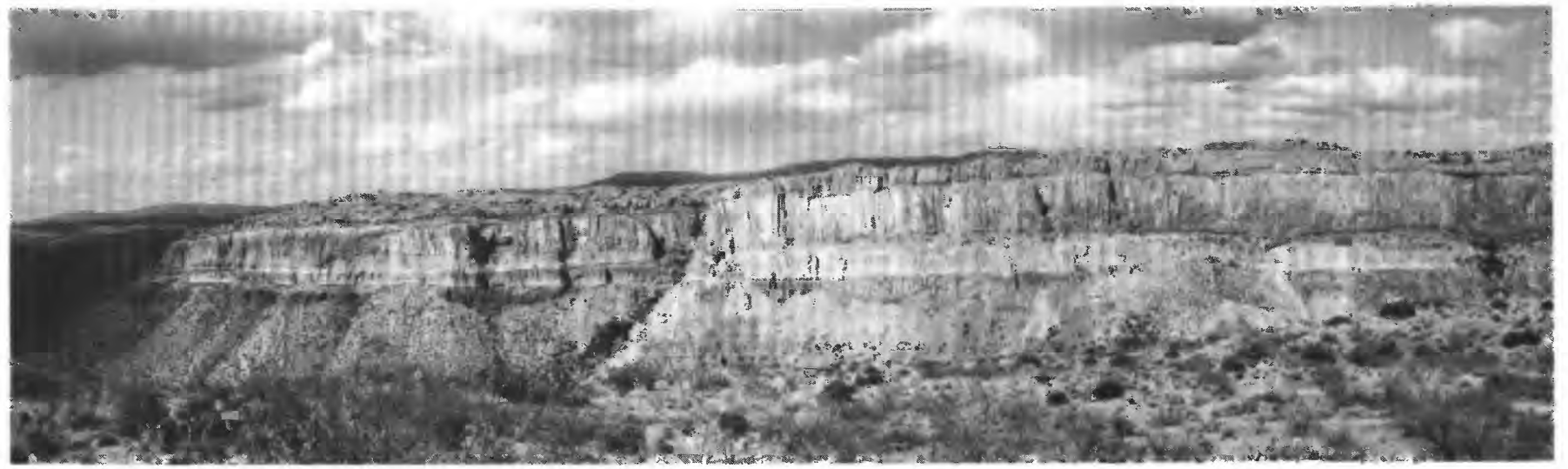

FIGURE 16.-Distal margin of welded zone of Aravaipa Member, showing change from section composed mostly of columnar-jointed zone to completely nonwelded zone at left (see accompanying sketch). Lower part of cliff (right) is slightly darker, indicating denser welding and development of vuggy zone (vug), which to left has been replaced by columnar-jointed zone (c). Nonwelded pink tuff (p) farther left replaces lower part of columnar-jointed zone and still farther left overlies and extends beyond columnar-jointed tuff. Aravaipa Member 
at locs. $1 \mathrm{~A}, 2 \mathrm{~A}$, and 3 . It was not definitely recognized in the X-ray diffractographs because it is a minor constituent where present, and its peaks are close to some of the peaks of cristobalite, quartz, and feldspar (see figs. $7 C, D$ ).

Quartz rather than cristobalite (and tridymite?) occurs in most of the vapor-phase zone (see figs. $19 C, D$ ). The cristobalite and tridymite probably inverted to high-temperature quartz during a prolonged spell at temperatures just below the inversion temperature. The quartz represents neither the granophyric crystallization that occurs in some very thick ash flows nor the conversion of cristobalite and tridymite that occurs in older ash flows. Most of the cristobalite detected by X-ray in the nonwelded pink tuff (fig. 22) probably represents devitrification that formed around lithophysae.

Chemical analyses (table 6) were made for two samples of the'vitrophyre (one brown and one black) and one each of the devitrified, platy-jointed, and vaporphase zones. Minor-element contents of these samples are given in table 4.

The whole-rock analyses show that chemical differences between zones in the Aravaipa Member are very small. The most significant differences are the higher water content in vitrophyre than in the crystallized tuff and a high oxidation state of iron in the crystallized tuff than in the black vitrophyre. Both these characteristics are observed in ash-flow tuffs throughout the western United States and elsewhere.

The high water content of the vitrophyre causes problems in comparing relative abundance of the nonvolatile constituents, and probably is the result of secondary hydration rather than of magmatic, deposi- tional, or cooling processes (Ross and Smith, 1955, p. 1086-1088). To more readily compare the nonvolatile elements, the analyses have been recalculated on a water-free basis; CIPW norms and Barth cation amounts are also listed. The recalculated analyses show a decrease in sodium in the vitrophyre compared to the crystallized rocks. Solution of sodium, some of it in greater amounts than reported here, has been reported from vitric parts of many rhyolitic rocks (Lipman and Christiansen, 1964; Lipman, 1965). The other changes are minor and may reflect random variations among the samples or crystal and lithic fragments. Silica shows an increase; aluminum, magnesium, and calcium show very slight decreases in the vitrophyre compared with the crystallized parts of the ash flow. These changes are the reverse of those found by Lipman and Christiansen (1964), who explain the higher aluminum, magnesium, and calcium content of the glassy nonwelded tuff by the presence of $5-10$ percent of calcic montmorillonitic clay coating glass shards. The vitrophyres in the Aravaipa Member were too densely welded for clay to have developed. The relative amounts of $\mathrm{CaO}, \mathrm{Na}_{2} \mathrm{O}$, and $\mathrm{K}_{2} \mathrm{O}$ in the five analyzed samples have been plotted on figure 24 (Nos. 1a-5a) and show a slight but progressive upward increase in $\mathrm{Na}_{2} \mathrm{O}$ and decrease in $\mathrm{K}_{2} \mathrm{O}$.

\section{CHANGES IN CHEMICAL COMPOSITION DUE TO ZEOLITIZATION}

The Aravaipa Member presents an excellent opportunity to compare the chemical composition of a nonzeolitized tuff with that of its zeolitized parts. Zeolitization took place only in the nonwelded parts of the

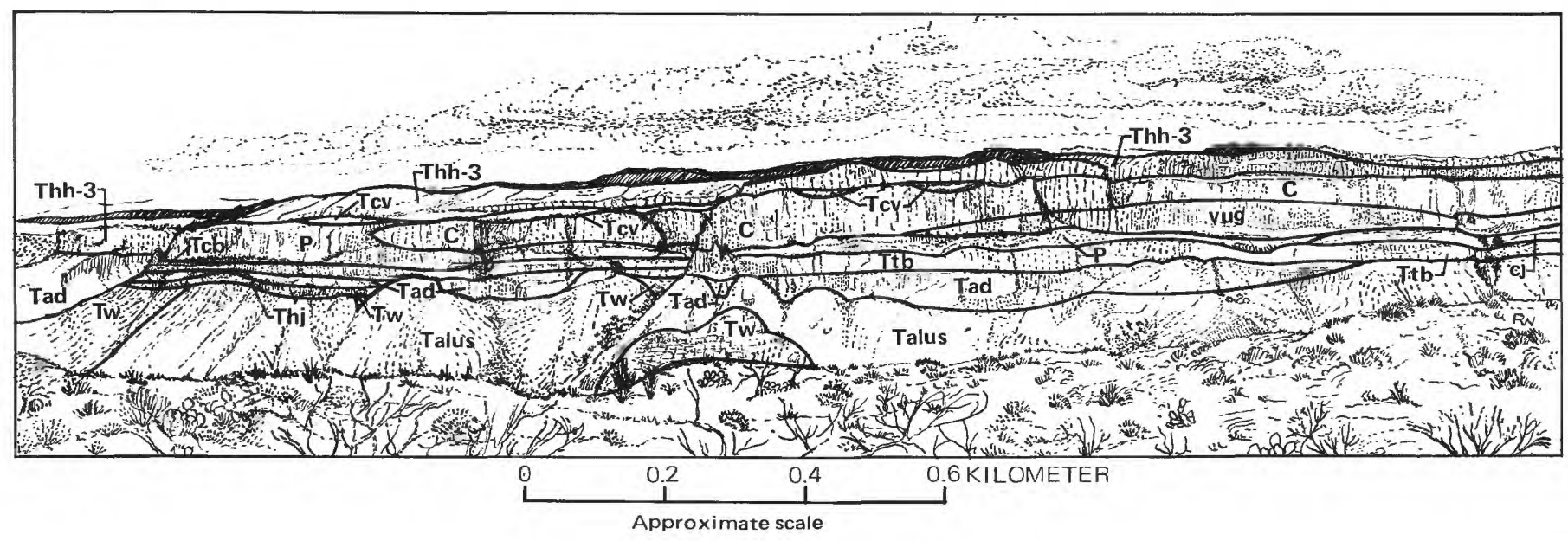

is separated locally from overlying Hells Half Acre Tuff Member (upper unit, Thh-3) by thin lenses of conglomerate (Tcv) derived from lower andesite of Virgus Canyon and is underlain by tuff of Bear Springs Canyon (Ttb), which consists of pink tuff, except for columnarjointed tuff $(\mathrm{Cj})$ at right. Beneath tuff of Bear Springs Canyon are andesite of Depression Canyon (Tad), Holy Joe Member (Thj), and Whitetail(?) Conglomerate (Tw). Photograph taken from near loc. 1A; end of welded part at loc. 1B (fig. 18). 


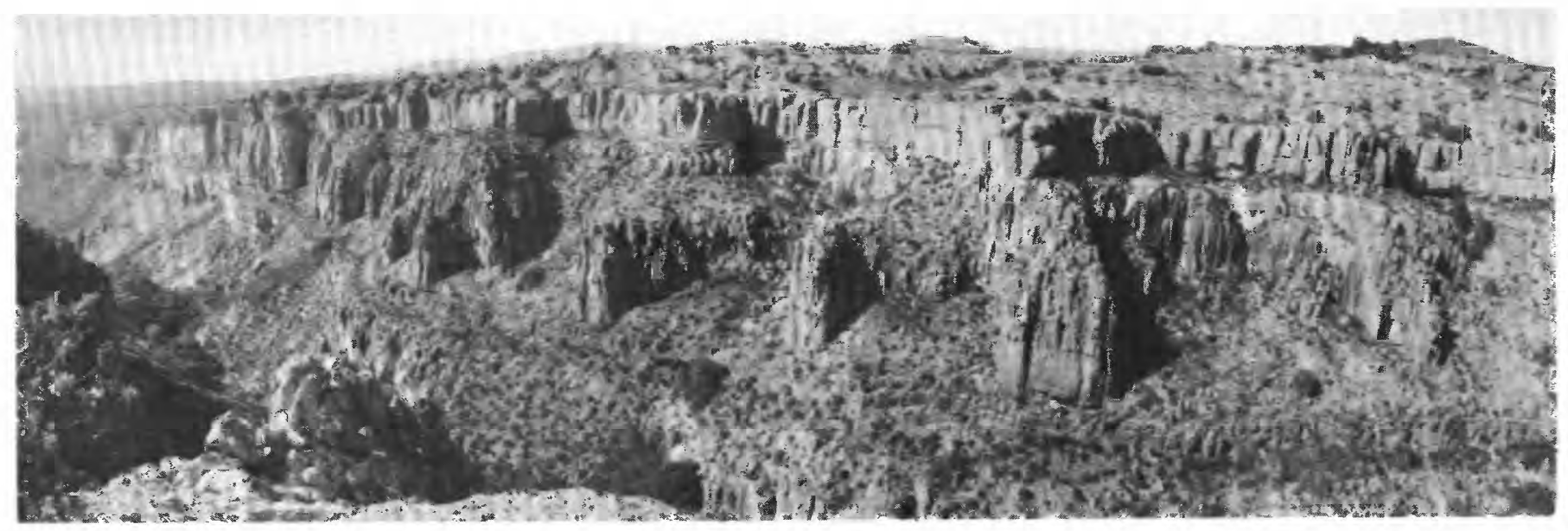

FIGURE 17.-Change from interior zonation in Aravaipa Member (right) to distal margin of ash flow (left). Most of photograph shows interior vertical zonation from vitrophyre (V) at base through vuggy zone (vug) to columnar-jointed zone (C) at top (see accompanying sketch). Platy-jointed zone not recognized in photograph; upper tuff has been removed by erosion. To the left, first vitrophyre and then vuggy zone are replaced by pink tuff (P). Part of exposure to left of vitrophyre and vuggy zones also shown in figure 16. Apsey Conglomerate

TABLE 6.-Chemical composition and comparison of glassy and crystallized parts, Aravaipa Member

|Major oxide analyses (weight percent) by P. Elmore, S. Botts, and G. Chloe by rapid methods described by Shapiro and Brannock (1962). See table 4 for minor-element analyses]

\begin{tabular}{|c|c|c|c|c|c|c|c|c|c|c|c|}
\hline \multicolumn{7}{|c|}{ Original analyses } & \multicolumn{5}{|c|}{ Recalculated without $\mathrm{H}_{2} \mathrm{O}$ and $\mathrm{CO}_{2}$} \\
\hline & 1 & 2 & 3 & 4 & 5 & & $1 \mathrm{a}$ & $2 a$ & $3 \mathrm{a}$ & $4 \mathrm{a}$ & $5 a$ \\
\hline $\mathrm{SiO}_{2}$ & 73.4 & 73.2 & 73.4 & 74.0 & 74.1 & $\mathrm{SiO}_{2}$ & 76.0 & 75.8 & 74.6 & 74.9 & 75.1 \\
\hline $\mathrm{Al}_{2} \mathrm{O}_{3}^{2}$ & 12.7 & 12.8 & 13.6 & 13.6 & 13.5 & $\mathrm{Al}_{2} \stackrel{2}{\mathrm{O}}_{3}$ & 13.1 & 13.3 & 13.8 & 13.8 & 13.7 \\
\hline $\mathrm{Fe}_{2} \mathrm{O}_{3}^{3}$ & 1.1 & .83 & 1.2 & 1.2 & 1.2 & $\mathrm{Fe}_{2} \mathrm{O}_{3}$ & 1.1 & .86 & 1.2 & 1.2 & 1.2 \\
\hline $\mathrm{FeO}$ & .13 & .34 & .08 & .05 & .04 & $\mathrm{FeO}$ & .13 & .35 & .08 & .05 & .04 \\
\hline MgO --.-- & .25 & .24 & .47 & .39 & .35 & MgO - - & .26 & .25 & .48 & .39 & .35 \\
\hline $\mathrm{CaO}$ & .38 & .39 & .44 & .38 & .46 & $\mathrm{CaO}$ & .39 & .40 & .45 & .38 & .47 \\
\hline $\mathrm{Na}_{2} \mathrm{O}$ & 3.2 & 3.3 & 3.6 & 3.8 & 3.8 & $\mathrm{Na}_{2} \mathrm{O}$ & 3.3 & 3.4 & 3.7 & 3.8 & 3.9 \\
\hline $\mathrm{K}_{2} \mathrm{O}^{2}$ & 5.4 & 5.0 & 5.2 & 5.0 & 4.9 & $\mathrm{~K}_{2} \mathrm{O}$ & 5.6 & 5.2 & 5.3 & 5.1 & 5.0 \\
\hline $\mathrm{H}_{2}^{2} \mathrm{O}+\ldots$ & 3.0 & 3.1 & .93 & .80 & .77 & $\mathrm{TiO}_{2}$ & .22 & .23 & .24 & .24 & .24 \\
\hline $\mathrm{H}_{2}^{2} \mathrm{O}-$ & .40 & .38 & .93 & .44 & .61 & $\mathrm{P}_{2} \mathrm{O}_{5}^{2}$ & .03 & .04 & .06 & .04 & .04 \\
\hline $\mathrm{TiO}_{2}^{2}$ & .21 & .22 & .24 & .24 & .24 & MnO --------- & .07 & .11 & .08 & .08 & .07 \\
\hline $\mathrm{P}_{2} \mathrm{O}_{4}^{2}$ & .03 & .04 & .06 & .04 & .04 & & & & & & \\
\hline MnO & .07 & .11 & .08 & .08 & .07 & Total ---- & 100.20 & 99.94 & 99.98 & 99.98 & 100.11 \\
\hline \multirow{4}{*}{$\mathrm{CO}_{2}$} & $<.05$ & $<.05$ & $<.05$ & $<.05$ & $<.05$ & & & & & & \\
\hline & 100 & 100 & 100 & 100 & 100 & & & & & & \\
\hline & & \multicolumn{4}{|c|}{ CIPW norms } & & \multicolumn{2}{|c|}{ Barth cations } & & & \\
\hline & 1 & 2 & 3 & 4 & 5 & & 1 & 2 & 3 & 4 & 5 \\
\hline Quartz -.-.-.-.-. & 34.1 & 35.0 & 31.6 & 31.9 & 32.3 & $\mathrm{Si}$ & 71.0 & 71.0 & 69.6 & 69.8 & 70.0 \\
\hline Orthoclase -..-- & 32.9 & 30.6 & 31.2 & 29.9 & 29.3 & Al & 14.5 & 14.6 & 15.2 & 15.1 & 15.0 \\
\hline Albite & 28.0 & 28.9 & 31.0 & 32.6 & 32.6 & $\mathrm{Fe}^{+3}$ & .80 & .61 & .86 & .85 & .85 \\
\hline Anorthite --..- & 1.7 & 1.7 & 1.8 & 1.6 & 2.1 & $\mathbf{F e}^{+2}$ & .11 & .28 & .06 & .04 & .03 \\
\hline Corundum ------ & 1.0 & 1.4 & 1.4 & 1.4 & 1.2 & Mg - & .36 & .35 & .66 & .55 & .49 \\
\hline Enstatite ----- & .64 & .62 & 1.0 & .98 & .88 & $\mathrm{Ca}-$ & .39 & .41 & .45 & .38 & .47 \\
\hline Magnetite ------ & .04 & .85 & -- & .. & -- & $\mathrm{Na}$ & 6.0 & 6.2 & 6.6 & 7.0 & 7.0 \\
\hline Hematite ------ & 1.1 & .28 & 1.2 & 1.2 & 1.2 & K - & 6.7 & 6.2 & 6.3 & 6.0 & 5.9 \\
\hline Ilmenite -------- & .41 & .43 & .35 & .28 & .24 & Ti - - & .15 & .16 & .17 & .17 & .17 \\
\hline Rutile ----------- & -- & -- & .06 & .10 & .12 & P - & .02 & .03 & .05 & .03 & .03 \\
\hline Apatite -..--- & .07 & .10 & .14 & .10 & .10 & Mn - - & .06 & .09 & .06 & .06 & .06 \\
\hline \multirow[t]{3}{*}{ Total } & 99.96 & 99.88 & 99.75 & 100.06 & 100.04 & Total ---- & 100.09 & 99.93 & 100.01 & 99.98 & 100.00 \\
\hline & & & & & & Fe total - - & .91 & .89 & .92 & .89 & .88 \\
\hline & & & & & & $\mathrm{Fe}^{+2} / \mathrm{Fe}$ total --- & .12 & .31 & .06 & .04 & .03 \\
\hline
\end{tabular}

NotE: Samples 1, 2 from east of Oak Springs Canyon, near center sec. 5 , T. 7 S., R. 18 E., loc. 6 A, fig. 18. Samples 3-5 from upper Bear Springs Canyon, center sec. 4, T. 7 S., R. 18 E., loc. 6B, fig. 18. 1, Brown vitrophyre, H202E, Lab no. 159529. 2, Black vitrophyre, H202F, Lab no. 159530. 3, Devitrified zone, H202L, Lab no. 159531. 4, Platy-jointed zone, H202M, Lab no. 159532. 5, Vapor-phase zone, H202O, Lab no. 159533. 


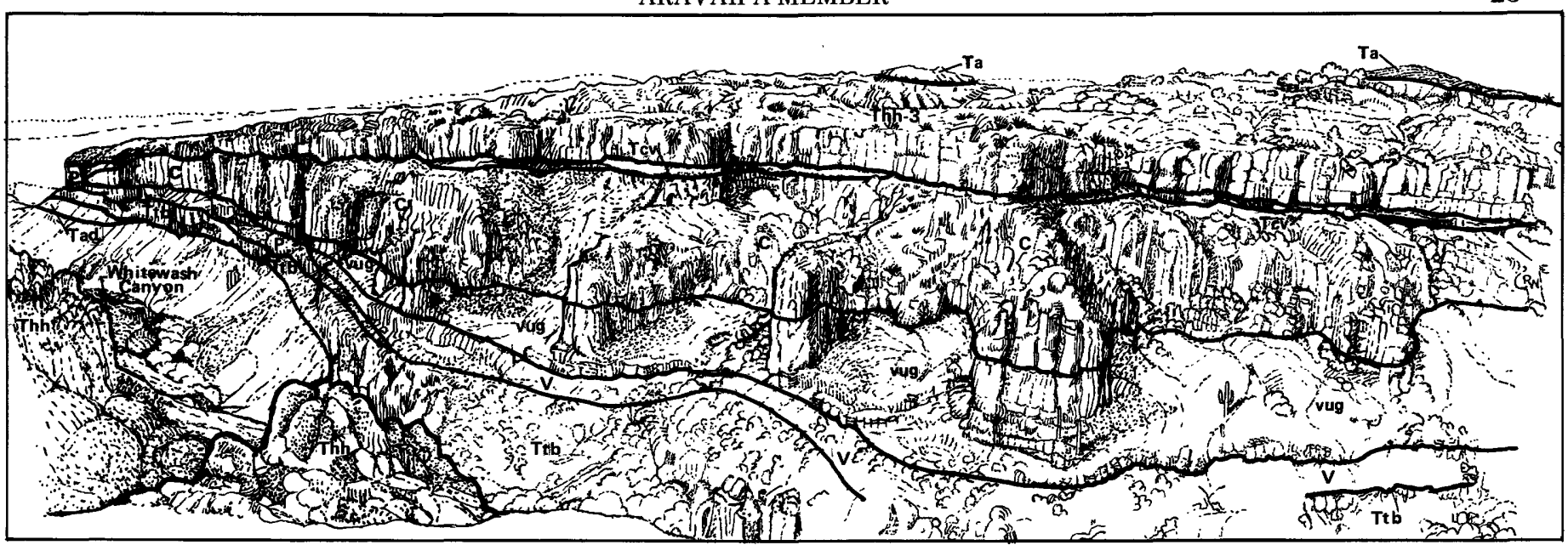

Member (Ta) forms hills in right distance. Hells Half Acre Tuff Member (upper unit, Thh-3) is separated locally from Aravaipa Member by thin lenses of conglomerate (Tcv) derived from lower andesite of Virgus Canyon. Tuff of Bear Springs Canyon (Ttb) underlies Aravaipa Member and is underlain by andesite of Depression Canyon (Tad). Photograph taken from south of loc. 4 (fig. 18). Distance from left to right side of photograph approximately $2 \mathrm{~km}$.

ash flow that had remained vitric during cooling. None of the devitrified or vapor-phase zones were altered (see figs. 22, $19 C, D$; and the X-ray diffractographs, figs. $7 D, E$ ) South of Aravaipa Canyon (fig. 22, locs. 1A, 2A, 2B, and 4), and in the west side of Cave Canyon, north of Aravaipa Canyon (Krieger, Johnson, and Bigsby, 1979), the nonwelded tuff was altered to clinoptilolite. On the east side of Cave Canyon, however (fig. 22, loc. 3), it was altered to mordenite below and to clinoptilolite above the columnar-jointed zone. Hoover and Shepard (1965) found that clinoptilolite, mordenite, and analcime formed in progressively deeper but overlapping zones. Mordenite, rather than clinoptilolite, may have formed below the columnar-jointed zone on the east side of Cave Canyon because this part of the ash flow was buried more deeply than it was to the west and south, owing to the gentle north-northeastward dip of the ash flow and to a thicker section of overlying Hells Half Acre Tuff Member. Zeolitization is believed to have occurred in an unsaturated zone above the water table and above impermeable rocks, conditions similar to those found by Hoover (1968) at the Nevada Test Site. Sheppard and Gude (1965), who compared vitric and zeolitized tuff by assuming constant $\mathrm{Al}_{2} \mathrm{O}_{3}$, concluded that formation of pure clinoptilolite from pure rhyolite glass should involve mainly gains in $\mathrm{H}_{2} \mathrm{O}$ and $\mathrm{CaO}$ and losses in $\mathrm{SiO}_{2}$ and $\mathrm{K}_{2} \mathrm{O}$.

The chemical analysis of the devitrified tuff (no. 3 from table 6) is compared to the analyses of the tuff that has been altered to clinoptilolite and to mordenite (table 7, nos. 1-3; also shown on table 7 are the analyses of tuff of Bear Springs Canyon, no. 4; the middle unit of Hells Half Acre Tuff Member, no. 5, both al- tered to clinoptilolite; and the unaltered rhyolite-obsidian member, no. 6). The assumption is made that the devitrified tuff is the closest available approximation to the original composition of the magma. The major change is a large increase in $\mathrm{H}_{2} \mathrm{O}$. To more readily compare the nonvolatile constituents, the analyses have been recalculated on a water-free basis. In addition to $\mathrm{H}_{2} \mathrm{O}$, the major changes during alteration to both clinoptilolite and mordenite have been an increase in $\mathrm{CaO}$ (greater when altered to mordenite) and losses in $\mathrm{Na}_{2} \mathrm{O}$ (greater when altered to clinoptilolite) and $\mathrm{K}_{2} \mathrm{O}$ (greater when altered to mordenite). Clinoptilolite shows a small increase in $\mathrm{MgO}$ and $\mathrm{SiO}_{2}$, whereas mordenite shows little change; some of these differences may be due to minute xenoliths or xenocrysts. The relative amounts of $\mathrm{CaO}, \mathrm{Na}_{2} \mathrm{O}$, and $\mathrm{K}_{2} \mathrm{O}$ in all the zeolitized and nonzeolitized rocks (from table 7) are plotted in figure 24. The relative amounts of these constituents in the five samples of the Aravaipa Member (from recalculated analyses, table 6, columns 1-5) are also plotted as nos. 1a-5a.

\section{CONCLUSIONS}

The Aravaipa Member is an outstanding example of vertical and horizontal zonation in an ash-flow tuff that cooled as a unit. The remarkable exposures, especially along Whitewash Canyon, make it posssble to trace the complete change from the typical stacked-up interior zonation to the nonwelded distal margin. The Aravaipa Member is a classic area for study of ash-flow tuffs. Vertical and horizontal changes in welding, crystallization, specific gravity, and lithology of the ash 


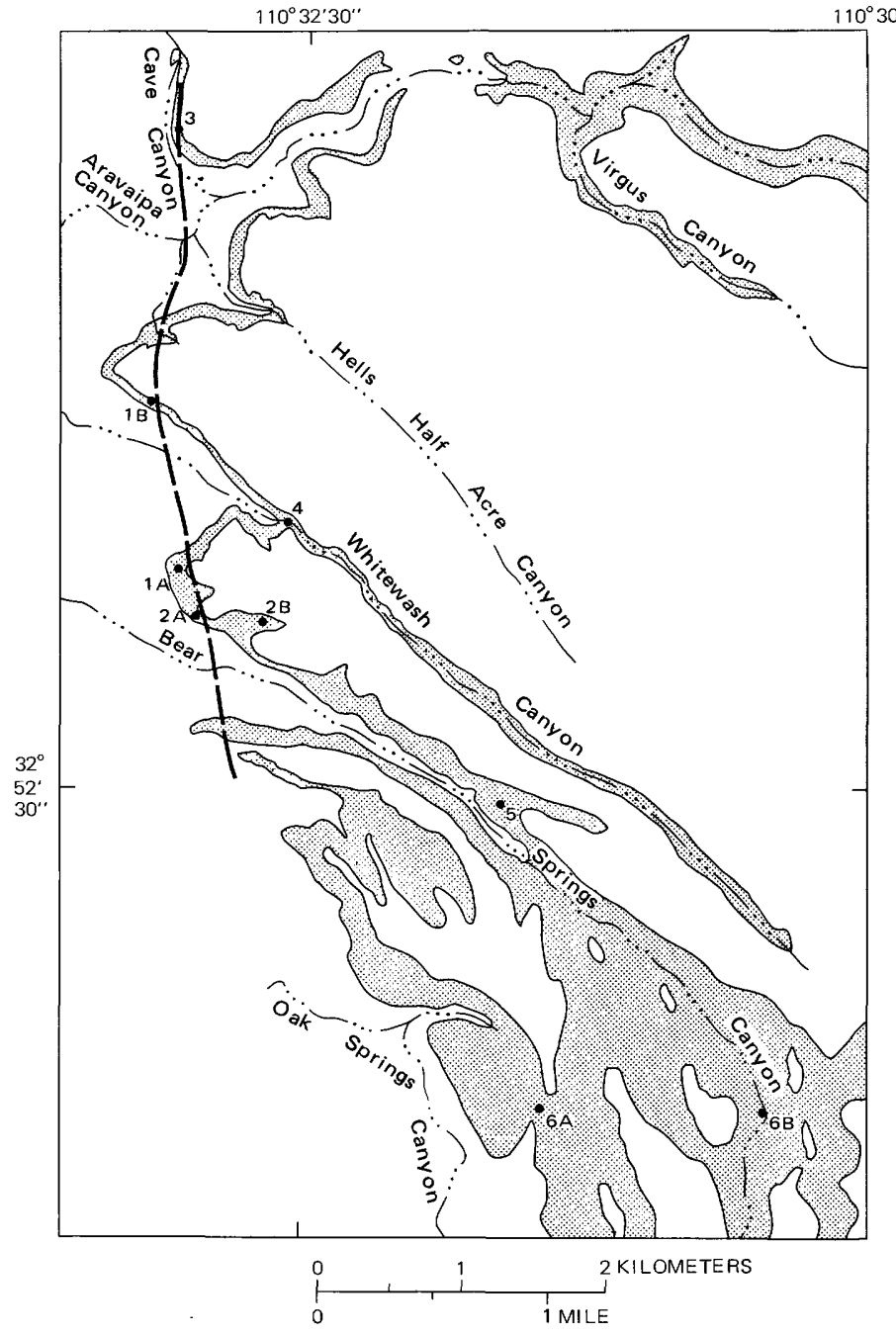

EXPLANATION

\begin{tabular}{cll} 
Locality & \multicolumn{1}{c}{ Location } & \multicolumn{1}{c}{ Specimen num } \\
1A & Bear Springs Canyon north & A-7, H341K, N, \\
1B & Whitewash Canyon north & \\
2A & Bear Springs Canyon north & H341 A-H, J \\
2B & Bear Springs Canyon north & A-1-6 \\
3 & Cave Canyon & H343A-H, J-M \\
4 & Whitewash Canyon south & A-8-16 \\
5 & Bear Springs Canyon south & A-17-25 \\
6A & Near Oak Springs Canyon & H202A-H \\
6B & Upper Bear Springs Canyon & H202I-R
\end{tabular}

FIGURE 18.-Map showing outcrop of Aravaipa Member (shaded), location of specimens, and approximate position of distal margin of columnar-jointed zone (heavy dashed line).

flow are due to decrease in temperature as distance from its source increased and as thinning of the ash flow against topographic highs caused more rapid cooling. The Aravaipa Member maintains its typical interior zonation for a minimum of $9 \mathrm{~km}$ in a east-west direction. The rapid thinning of the ash flow and the short distance (less than $0.7 \mathrm{~km}$ ) in which the change takes place (loc. 4 to loc. 1A, fig. 18) suggest that cooling was due more to the thinning against older rocks than to
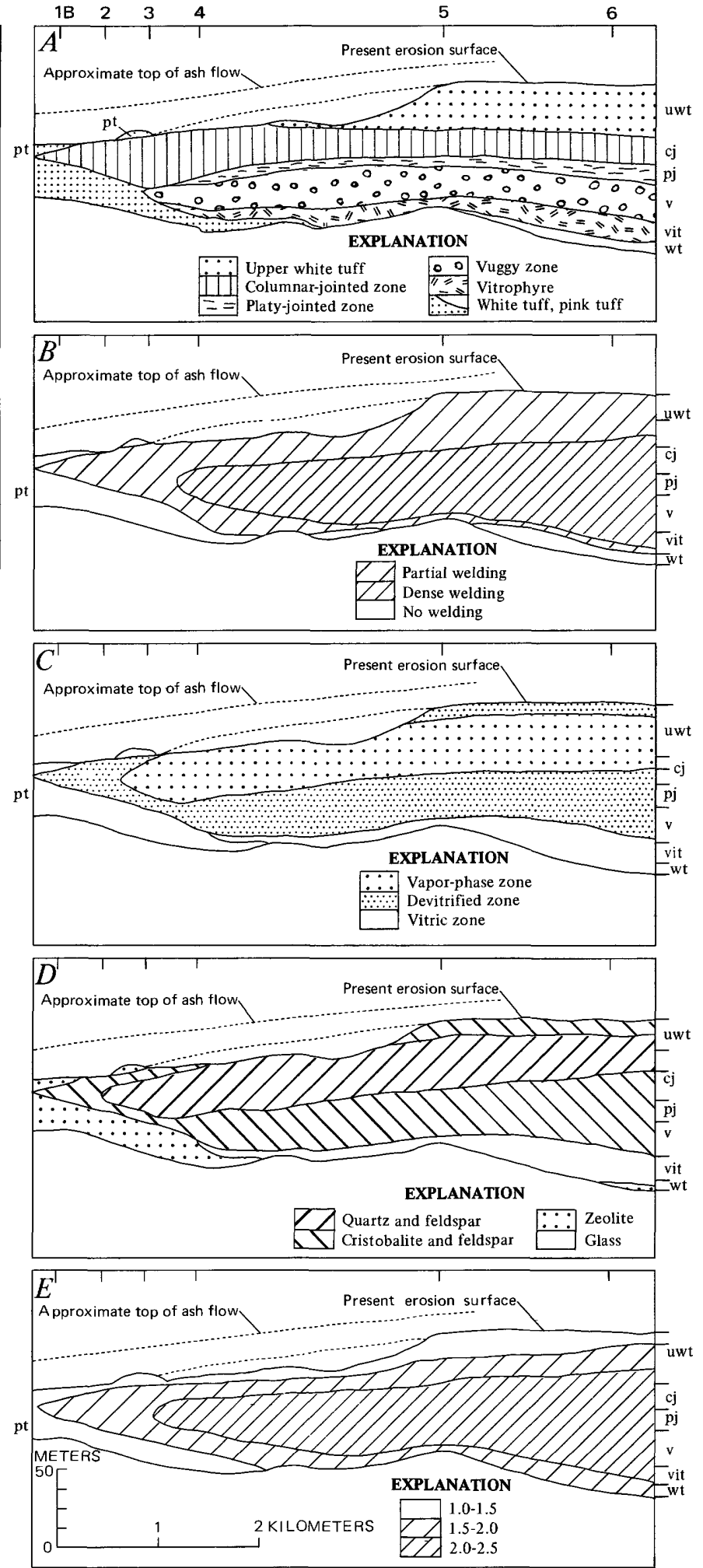

FIGURE 19.-Diagrammatic sketches of zones in Aravaipa Member. $A$, Lithology. $B$, Welding. $C$, Crystallization. $D$, Mineralogy. $E$, Specific gravity. $C$ and $D$ show probable features prior to zeolitization. Numbers and ticks at top show specimen localities (see fig. 18). Ticks (at right) represent boundaries of lithologic zones: uwt, upper white tuff; cj, columnar-jointed; pj, platy-jointed; v, vuggy; vit, vitrophyre; wt, white tuff; and (at left) pk, pink tuff. 


\section{EXPLANATION}

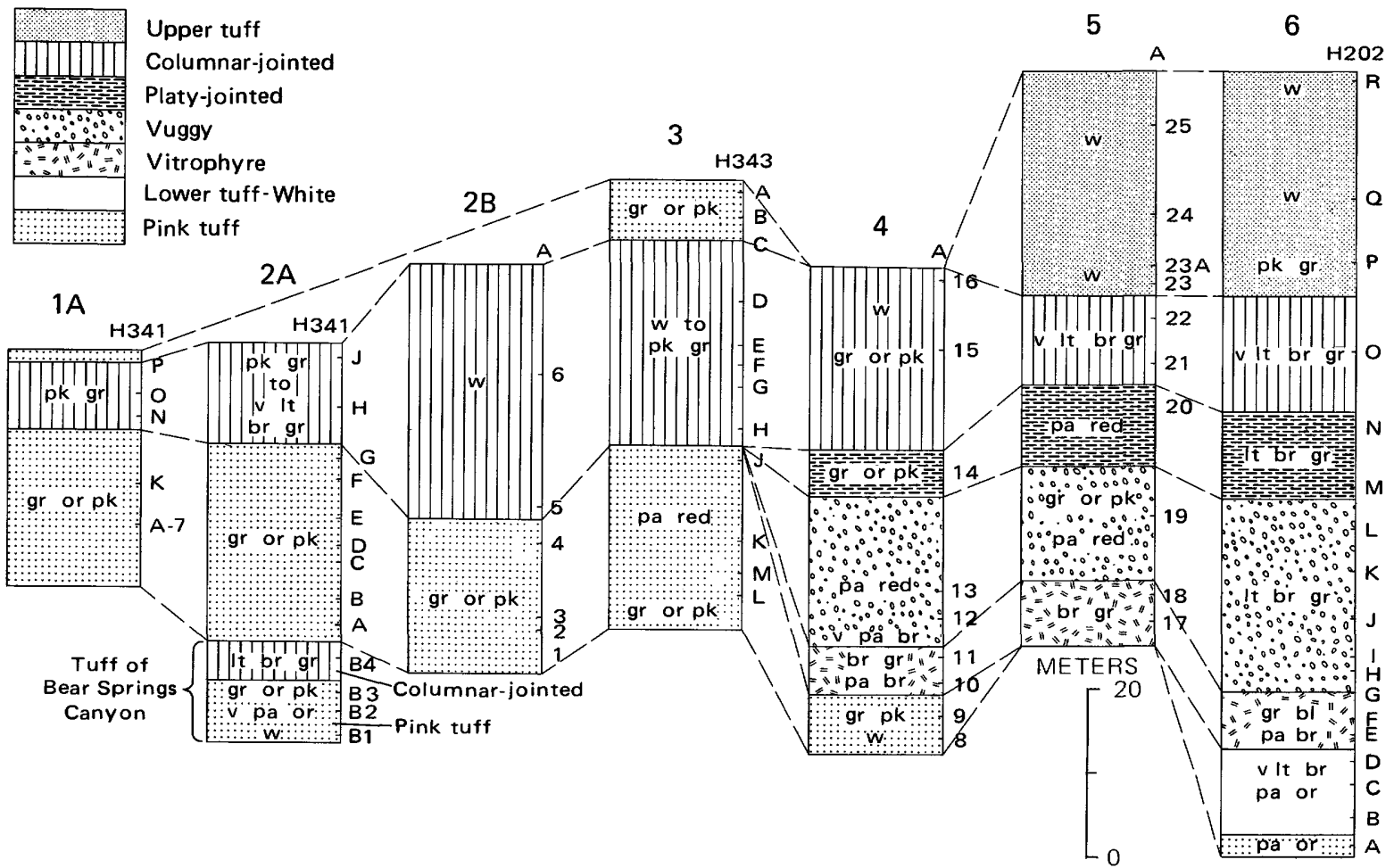

FIGURE 20.-Lithologic zones and color, Aravaipa Member, showing change from interior sequence (loc. 6) to distal margin of ash flow (loc. 1A) (see fig. 18 for locations). Color terms: bl, black; br, brown or brownish; d, dark; gr, gray orgrayish; lt, light; or, orange; pa, pale; pk, pink or pinkish; v, very; w, white. Underlying tuff of Bear Springs Canyon (bottom of loc. 2A) also shown.

TABLE 7.-Chemical analyses and comparisons of nonzeolitized and zeolitized Aravaipa Member, zeolitized tuff of Bear Springs Canyon and Hells Half Acre Tuff Member, and nonzeolitized rhyolite-obsidian member

(Major oxide analyses (weight percent), No. 1 by P. Elmore, S. Botts, and G. Chloe; Nos. $4-6$ by P. Elmore, L. Artis, G. Chloe, J. Glenn, S. Botts, H. Smith, and D. Taylor by rapid methods described by Shapiro and Brannock (1962); Nos. $4-6$ supplemented by atomic absorption; Nos. 2 . 3 by H. Smith by methods described by Shapiro (1967). See table 4 for minor-element analyses]

\begin{tabular}{|c|c|c|c|c|c|c|c|c|c|c|c|c|}
\hline \multirow[t]{2}{*}{ Mineral } & \multicolumn{6}{|c|}{ Original analyses } & \multicolumn{6}{|c|}{ Recalculated without $\mathrm{H}_{2} \mathrm{O}$ and $\mathrm{CO}_{2}$} \\
\hline & 1 & 2 & 3 & 4 & 5 & 6 & 1 & 2 & 3 & 4 & 5 & 6 \\
\hline $\mathrm{SiO}_{2}$ & 73.4 & 67.0 & 63.6 & 65.5 & 69.3 & 74.6 & 74.6 & 75.2 & 74.4 & 76.1 & 76.6 & 75.3 \\
\hline $\mathrm{Al}_{2} \mathrm{O}_{3}$ & 13.6 & 12.5 & 12.1 & 12.4 & 11.5 & 13.5 & 13.8 & 14.0 & 14.1 & 14.4 & 12.8 & 13.6 \\
\hline $\mathrm{Fe}_{2} \mathrm{O}_{3}^{3}$ & 1.2 & 1.2 & 1.0 & 1.2 & .92 & 1.3 & 1.2 & 1.4 & 1.2 & 1.4 & 1.0 & 1.3 \\
\hline $\mathrm{FeO}$ & .08 & .12 & .08 & .16 & .16 & .12 & .08 & .13 & .09 & .19 & .18 & .12 \\
\hline MgO & .47 & 1.0 & .40 & 1.5 & .72 & .11 & .48 & 1.1 & .47 & 1.7 & .8 & .11 \\
\hline $\mathrm{CaO}$ & .44 & 2.6 & 3.0 & 2.9 & 2.3 & 38 & .45 & 2.9 & 3.5 & 3.4 & 2.5 & .38 \\
\hline $\mathrm{Na}_{2} \mathrm{O}$ & 3.6 & .78 & 1.9 & .80 & 1.4 & 4.2 & 3.7 & .88 & 2.2 & .93 & 1.5 & 4.2 \\
\hline $\mathrm{K}_{2} \mathrm{O}$ & 5.2 & 3.5 & 3.0 & 1.3 & 3.6 & 4.5 & 5.3 & 3.9 & 3.5 & 1.5 & 4.0 & 4.5 \\
\hline $\mathrm{H}_{2}^{2} \mathrm{O}^{+} \ldots \ldots$ & .93 & 7.6 & 7.9 & 3.3 & 2.2 & .42 & -. & -- & .. & -- & -- & -- \\
\hline $\mathrm{H}_{2}^{2} \mathrm{O}^{-}$ & .93 & 4.0 & 5.6 & 10.3 & 7.5 & .10 & $\ldots$ & -- & -- & -- & .- & -- \\
\hline $\mathrm{TiO}_{2}$ & .24 & .16 & .12 & .21 & .15 & .21 & .24 & .18 & .14 & .24 & .17 & .21 \\
\hline $\mathrm{P}_{2} \mathrm{O}_{5}^{2}$ & .06 & .15 & .04 & .03 & .04 & .03 & .06 & .06 & .05 & .03 & .04 & .03 \\
\hline MnO & .08 & .07 & .06 & .06 & .07 & .10 & .08 & .08 & .07 & .07 & .08 & .01 \\
\hline $\mathrm{CO}_{2}$ & $<.05$ & .22 & .06 & $<.05$ & .11 & $<.05$ &.- &.- &.- & -- &.- & -- \\
\hline Total ..... & 100 & 100.90 & 99 & 100 & 99.97 & 100 & 99.99 & 99.83 & 99.72 & 99.96 & 99.87 & 99.76 \\
\hline
\end{tabular}

1. Aravaipa Member, devitrified, H202L, Lab 159531, upper Bear Springs Canyon, center sec. 4, T. 7 S., R. 18E., loc. $6 B$, fig. 18.

2. Aravaipa Member altered to clinoptilolite, A-4, Lab M126691W, NW1/4 sec. 30, T. 6 S., R. 19 E., between Whitewash and Bear Springs Canyons, loc. 2B, fig. 18.

3. Aravaipa Member, altered to mordenite, H343M, Lab M126692W, west edge N1/2 sec. 18, T. 6 S., R. 18 E., Cave Canyon, loc. 3, fig. 18.

4. Tuff of Bear Springs Canyon(?), altered to clinoptilolite, H414, Lab M101324W, east edge, N1/2 sec. 4, T. 7S., R. 18 E., loc. 7, fig. 2.

5. Hells Half Acre Tuff Member, middle unit, altered to clinoptilolite, H410, Lab M101323W, north of Aravaipa Canyon, east of Cave Canyon, NW1/4 sec. 18, T. 6 S., R. 18 E., loc. 8 , fig. 2.

6. Rhyolite-obsidian member, unaltered, H409, Lab M101317W, north of Aravaipa Canyon, east of Javalina Canyon, SE cor. sec. 7, T. 6 S., R. 18 E., loc. 9 , fig. 2. 


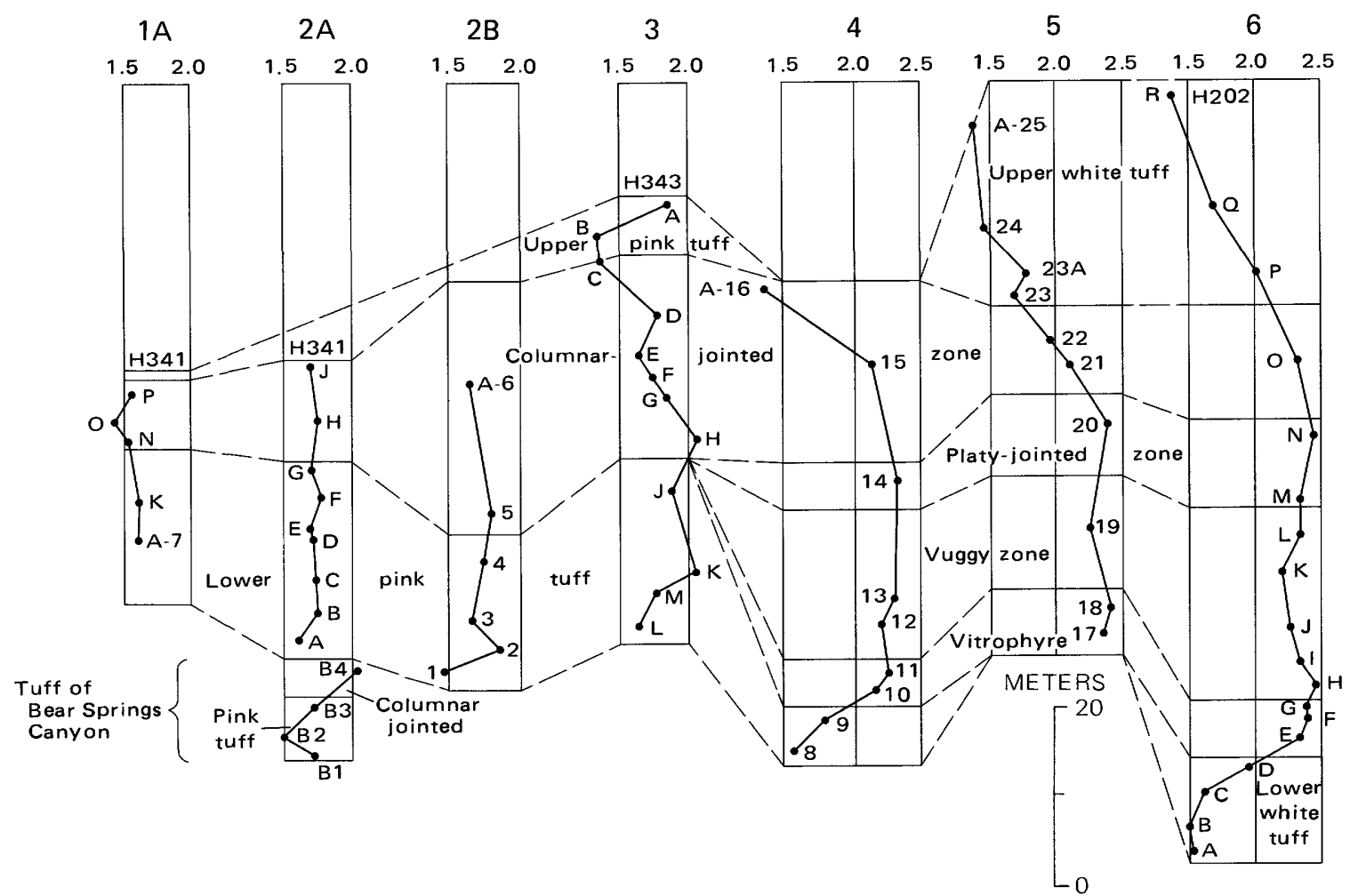

FIGURE 21.-Specific gravity, Aravaipa Member, superimposed on lithologic zones, showing change from interior sequence (loc. 6) to distal margin (loc. 1A) (see fig. 18 for locations). Also shows underlying tuff of Bear Springs Canyon (bottom of loc. 2A).

distance from the source. The distal margin of the ash flow cooled so rapidly that it remained vitric, and this nonwelded vitric part was later completely zeolitized by ground water.

\section{TUFF OF BEAR SPRINGS CANYON}

The tuff of Bear Springs Canyon $(25 \mathrm{~m})$ between Bear Springs and Whitewash Canyons is a rhyolite ash-flow tuff that is nearly coextensive with the overlying Aravaipa Member (figs. 16 and 17). It is composed of shards, pumice lapilli, crystal and accidental fragments, and small lithophysae. The lower part (0$15 \mathrm{~m}$ ) is pink tuff, largely altered to clinoptilolite; the upper part $(0-10 \mathrm{~m})$ is very light olive-gray to lightbrownish-gray columnar-jointed tuff whose groundmass is composed largely of quartz and feldspar. The lithologic zones, specific gravities, and mineral compositions of four specimens collected vertically across the tuff are shown in figures 20-22, loc. 2A, below the Aravaipa Member. The pink tuff represents the nonwelded part, and the gray columnar-jointed tuff represents the zone of vapor-phase crystallization of an ash flow that was erupted at temperatures not far above the minimum necessary for welding, as indicated by the very minor welding and the absence of a vitrophyre. The higher specific gravity in the columnarjointed zone may be due to slight welding. The lower specific gravity in the middle part of the pink tuff may be caused by large pumice lapilli, common in this part of the tuff. Both parts of the ash flow closely resemble the overlying pink tuff and columnar-jointed parts of the distal margin of the Aravaipa Member, but the lower columnar-jointed zone is not so extensive as the upper one. The two ash flows probably are similar in composition and closely related, but they are separated by a period of erosion, as evidenced by channels cut into or through the tuff of Bear Springs Canyon. No chemical analyses of the zeolitized tuff in this area are available. A chemical analysis of a pink tuff collected near the west edge of the Klondyke quadrangle (loc. 7 , fig. 2) is included in table 7 (column 4). It may be tuff of Bear Springs Canyon, but it probably is one of the tuffs in the lower part of Simon's $(1964$, p. 81) lower tuff unit. This specimen is composed of clinoptilolite with traces of quartz, feldspar, and biotite, similar to the pink tuff of Bear Springs Canyon (fig. 22, loc. 2A). Its recalculated analysis, however, suggests that it originally may not have had the same composition as the tuff of Bear Springs Canyon or Aravaipa Member; 

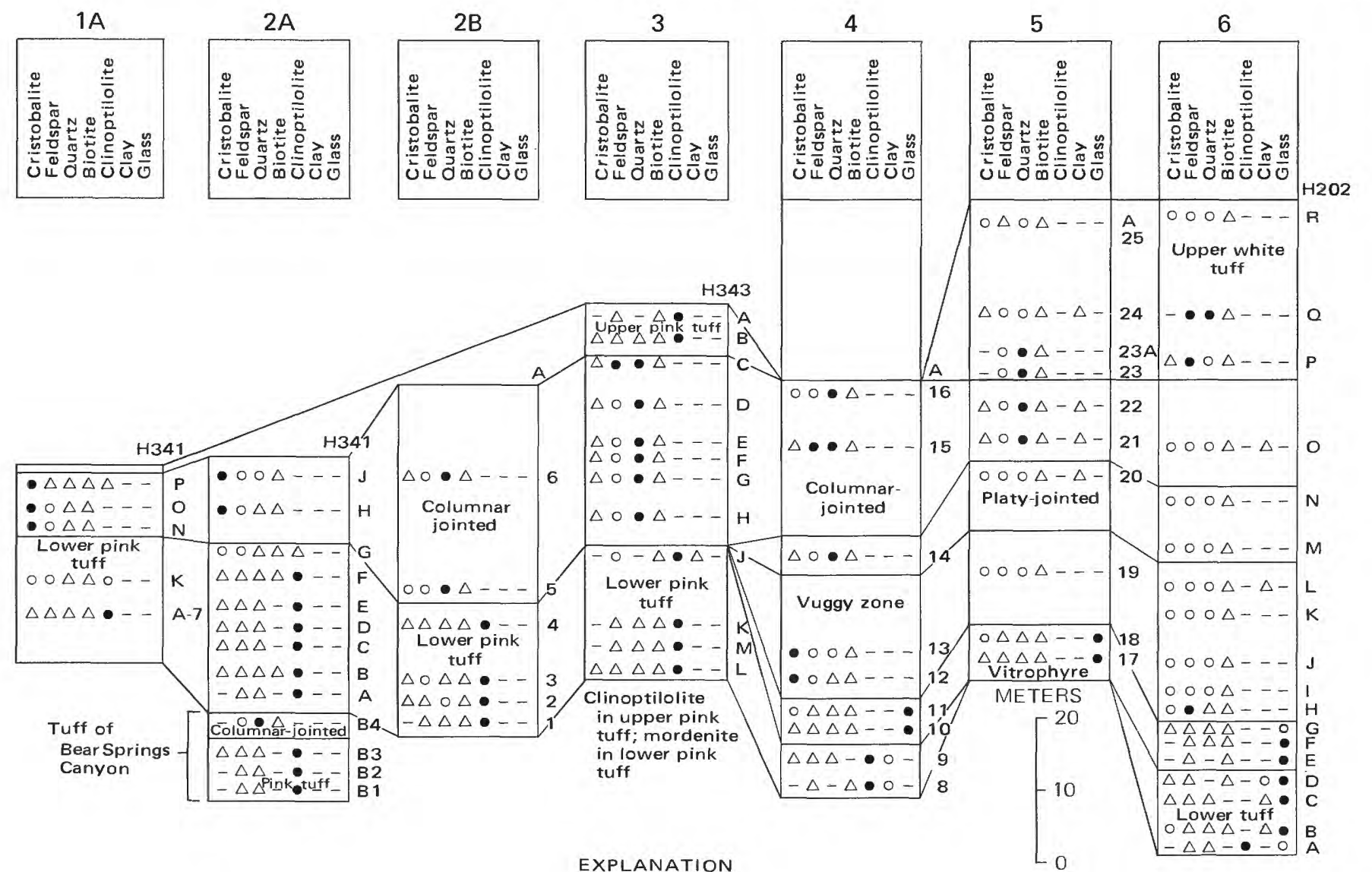

EXPLANATION

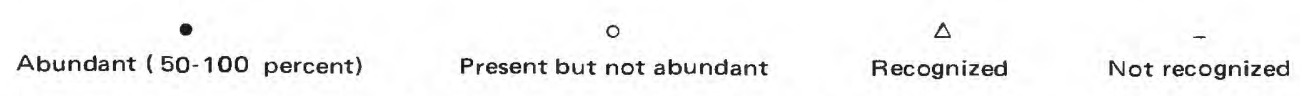

FIGURE 22.-Approximate composition of Aravaipa Member, superimposed on lithologic zones, showing change from interior sequence (loc. 6) to distal margin (loc. 1A) of ash flow. Apparent abundance estimated from X-ray diffractographs of bulk samples. In addition to minerals listed, specimens $\mathrm{H} 202 \mathrm{O}$ and $\mathrm{P}$ contain tridymite, and specimens H341L and $\mathrm{M}$ (between locations $1 \mathrm{~A}, 2 \mathrm{~A}$ ) appear to contain about equal parts of cristobalite and feldspar, with traces of biotite and quartz. Also shows underlying tuff of Bear Springs Canyon (loc. 2A).

it has a higher $\mathrm{MgO}$ and $\mathrm{CaO}$ and lower $\mathrm{K}_{2} \mathrm{O}$ content than the tuff of Bear Springs Canyon, and the relative amounts of $\mathrm{CaO}, \mathrm{Na}_{2} \mathrm{O}$, and $\mathrm{K}_{2} \mathrm{O}$ are different (see fig. 24). Additional data on tuff of Bear Springs Canyon are given in Krieger, Johnson, and Bigsby (1979).

\section{RHYOLITE-OBSIDIAN MEMBER}

Although the rhyolite-obsidian member is not an ash-flow tuff, it is described here briefly because of its probable close relationship to the Hells Half Acre Tuff Member. The rhyolite-obsidian member underlies an area of about $100 \mathrm{~km}^{2}$, about half of it in the northwest part of the Klondyke quadrangle. It extends from the north side of Aravaipa Canyon (fig. 2) to the southeastern part of the Christmas quadrangle (fig. 1). The member consists of gray and black flow-banded to massive perlitic to lithophysal obsidian and obsidian breccia, and finely laminated to contorted gray stony (de- vitrified) locally lithophysal rhyolite flow and flow breccia. A chemical analysis is given in table 7; see table 4 for minor-element content. The member was extruded as stubby flows and domes (see figs. 26,27 , and 28); only a few of the lowest ones reached the vicinity of Aravaipa Canyon. The member has an estimated maximum thickness of about $300 \mathrm{~m}$. It probably was erupted from at least two sources: one just north of the canyon on the boundary between the Klondyke and Holy Joe Peak quadrangles (fig. 2) and the other in the northeast part of the Holy Joe Peak quadrangle (Krieger, 1968a). Any other earlier sources have been buried by younger flows. The stratigraphic relations of the rhyolite-obsidian member to other members of the Galiuro Volcanics and their correlation with units in the Christmas quadrangle are given in figure 3 (see especially footnote 1 , in Klondyke quadrangle) and discussed briefly by Creasey and Krieger (1978). 

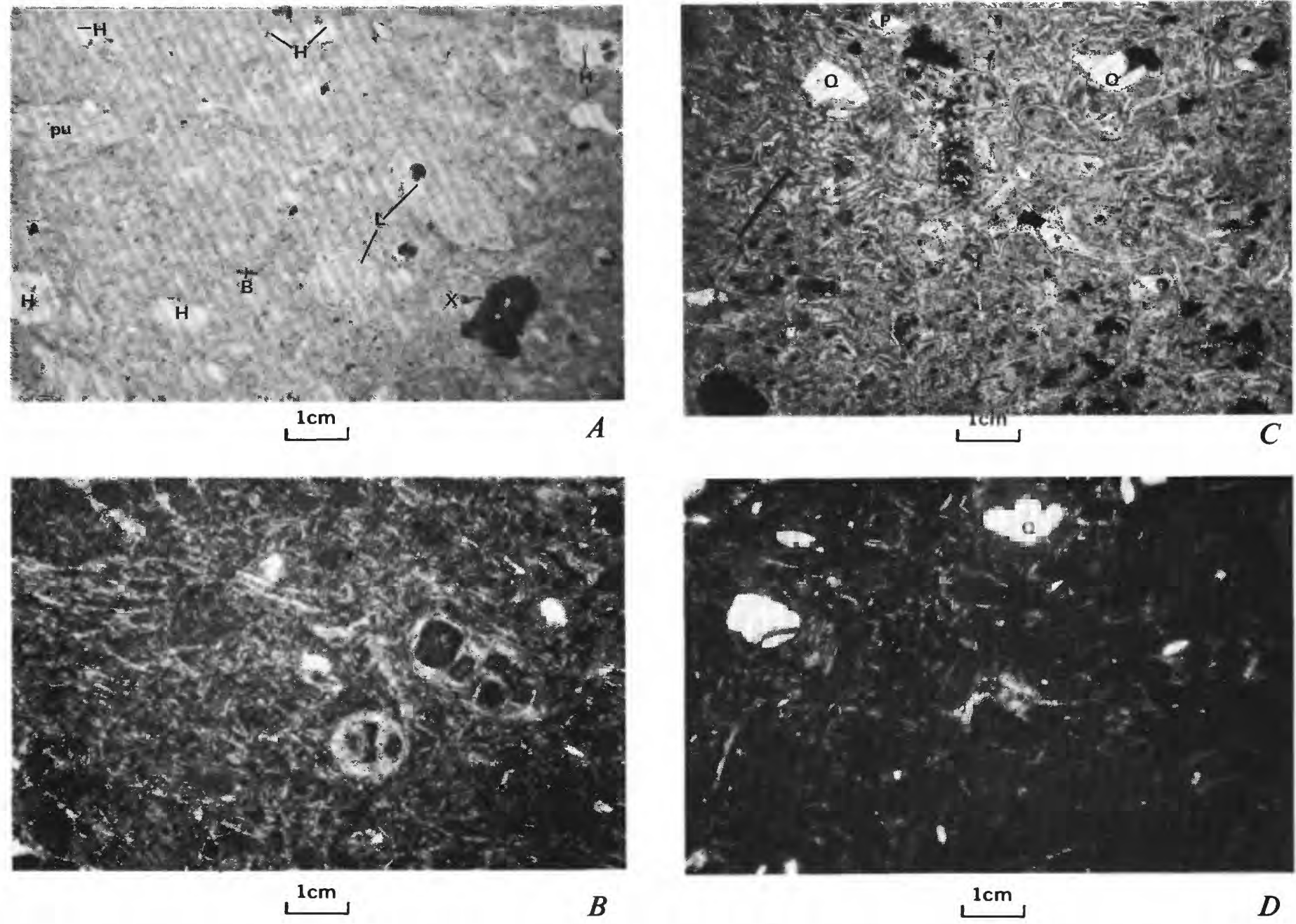

FIGURE 23.-Photomicrographs of specimens from near distal margin of Aravaipa Member. Biotite (B), hole (H), lithophysa (L), magnetite $(\mathrm{M})$, plagioclase $(\mathrm{P})$, pumice (pu), quartz $(\mathrm{Q})$, xenolith or xenocryst $(\mathrm{X})$. Plane polarized light, except as noted. A, Nonwelded pink tuff (H341A) from base of location 2A. Altered to clinoptilolite. Shard, glass bubble, and pumice structure well preserved. Some dark spots are grinding material. $B$, Same view as $A$, crossed nicols. Structure preserved because of axiolitic replacement by clinoptilolite. $C$, Nonwelded pink tuff (H341D). Excellent preservation of shard structure in tuff that has been altered to clinoptilolite. $D$, Same view as $C$, crossed nicols. Crystallization coarser grained in large shard fragment. Tube structure (not shown) preserved, even though finely

\section{HELLS HALF ACRE TUFF MEMBER}

The Hells Half Acre Tuff Member $(0-150 \mathrm{~m})$, of rhyolite composition, extends from the northeastern part of the Holy Joe Peak quadrangle (fig. 2) to about $1.6 \mathrm{~km}$ north of Aravaipa Canyon and eastward into the Klondyke quadrangle for about $3.5 \mathrm{~km}$ (fig. 2). It crops out intermittently beneath the Apsey Conglomerate Member north of Aravaipa Canyon to the northwest corner of the Brandenburg Mountain quadrangle (Krieger, 1968a). North and south of the canyon, the member is thinner because the lower part laps against topographic highs of older members of the volcanic sequence and of prevolcanic rocks. Along Aravaipa Canyon the member can be readily separated into three

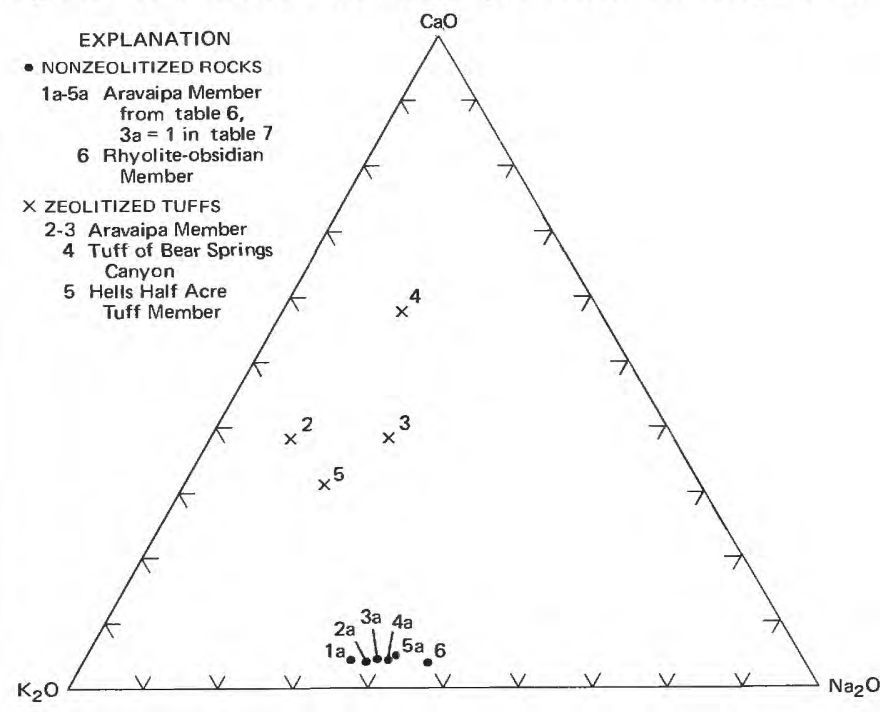



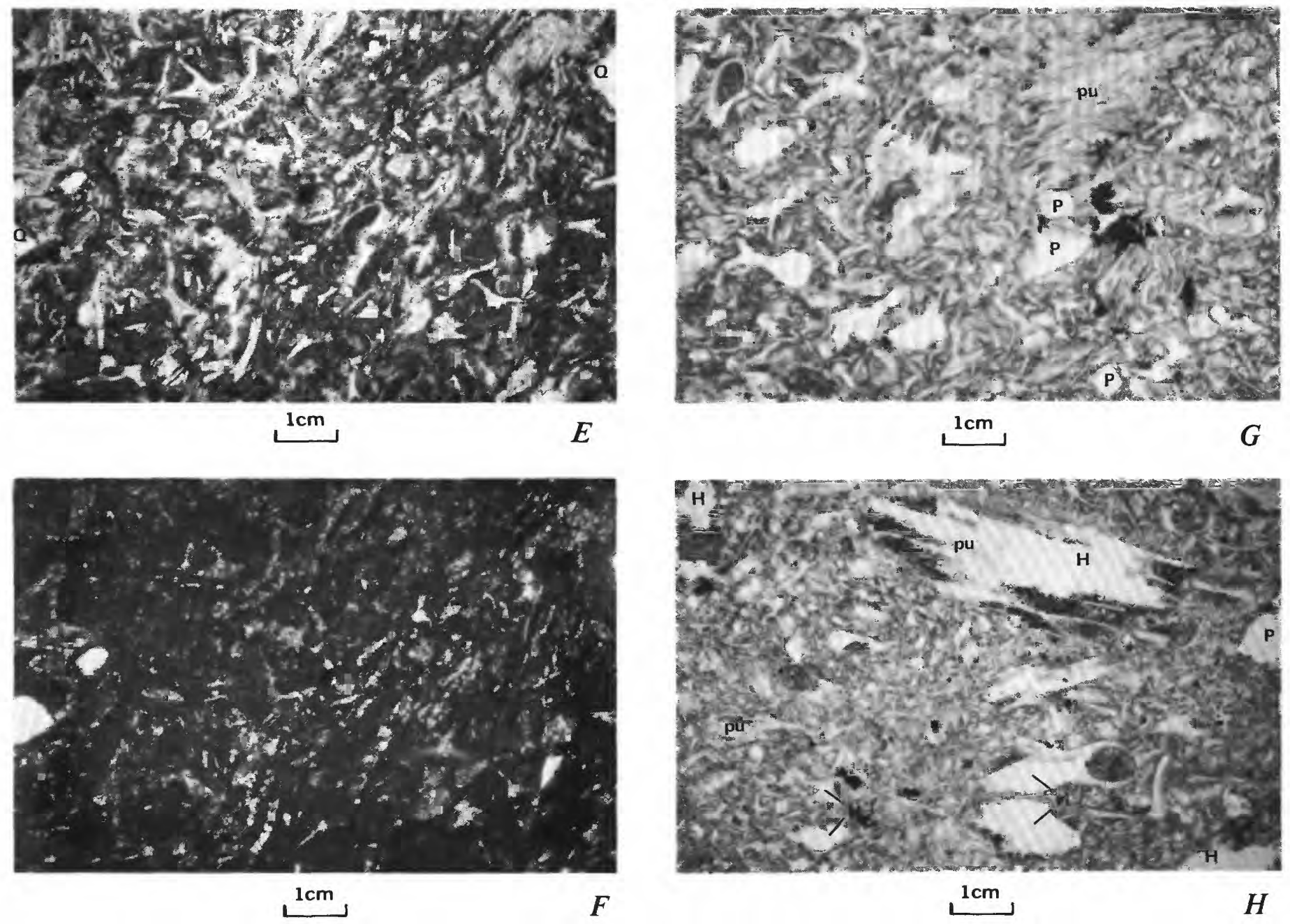

crystalline. $E$, Nonwelded pink tuff (H343J) altered to mordenite, showing shard structure. Abundant dust (dark). $F$, Same view as $E$, crossed nicols. Axiolitic intergrowths permit recognition of shard structure. G, Pink tuff (H343K), altered to mordenite; shard and pumice tube structure clearly defined. $H$, Specimen (H341P) from distal margin of columnar-jointed tuff (loc. 1A). Tuff only slightly welded, even though it still shows columnar jointing. With crossed nicols rock is finely devitrified; but X-ray diffractograph indicates that some birefringence is due to replacement by clinoptilolite.

units that are completely exposed in nearly inaccessible cliffs (fig. 25).

The lowest unit ( 0 to at least $15 \mathrm{~m}$ ) is a well-bedded cliff-forming porous yellowish-brown to brown rhyolite tuff with pumice lapilli and grains of quartz, feldspar, and biotite in a matrix of shards. Most of the vitric material has been altered to clinoptilolite. The unit, which was deposited in water impounded behind a tongue of rhyolite-obsidian (see figs. 2 and 26), is present along Aravaipa Canyon from about $0.7 \mathrm{~km}$ west of the mouth of Javalina ${ }^{3}$ Canyon to or nearly to the east

\footnotetext{
${ }^{3}$ Spelling is that used on Brandenburg Mountain topographic map.

Figure 24.-Relative amounts of $\mathrm{CaO}, \mathrm{Na}_{2} \mathrm{O}$, and $\mathrm{K}_{2} \mathrm{O}$ in zeolitized and nonzeolitized samples of Aravaipa Member, tuff of Bear Springs Canyon, Hells Half Acre Tuff Member, and rhyolite-obsidian member.
}

edge of the quadrangle and up Virgus Canyon for about $1.6 \mathrm{~km}$. Simons (1964, p. 91) describes a similar water-laid tuff at the base of his lowest subunit, just south of Aravaipa Canyon, about $2.4 \mathrm{~km}$ east of the quadrangle boundary.

The middle unit (up to $120 \mathrm{~m}$ maximum thickness between Javalina and Cave Canyons) is a massive cliff-forming white to very pale pink tuff. It is separated into two parts by a narrow bench or slope; the upper part thickens to the east and the lower part thickens to the west of Virgus Canyon. The unit is composed of pumice lapilli, some obsidian and rhyolite lapilli, and grains of quartz, feldspar, and minor biotite in a matrix of shards; some of the vitric material has been altered to clinoptilolite. The unit, at least the lower part, is considered a nonwelded or slightly 


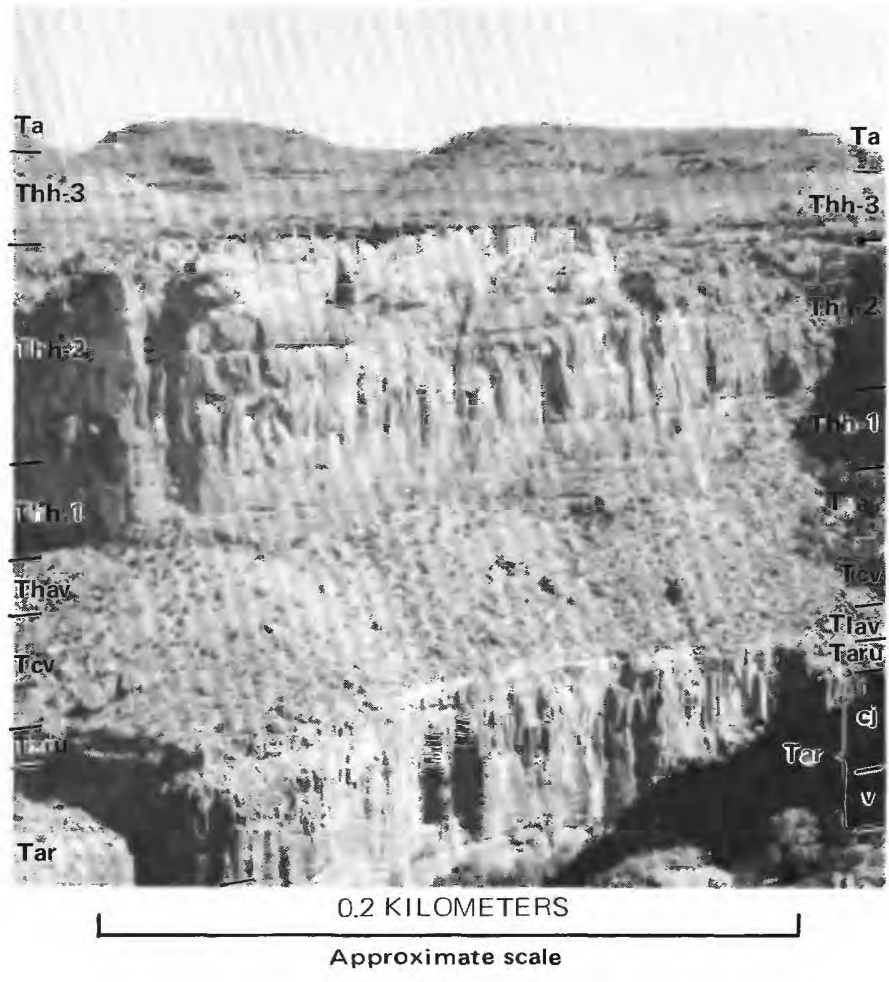

FIGURE 25.-Outcrop of units of Hells Half Acre Tuff Member (upper air-fall and reworked tuff, Thh-3; middle ash-flow(?) tuff, Thh-2; and lower water-laid tuff, Thh-1). Vague columnar jointing in lower part of middle unit suggests ash-flow tuff origin. Hells Half Acre Tuff Member overlain by Apsey Conglomerate Member (Ta) and underlain by a slope that largely conceals upper andesite (Tuav) and conglomerate (Tcv) of Virgus Canyon; lower andesite (Tlav) only at right side of picture. Lower cliff is Aravaipa Member (Tar, columnar-jointed (cj) and vuggy (v) zones; and Taru, upper slightly welded zone). View northeast across Aravaipa Canyon from just west of mouth of Virgus Canyon; Horse Camp Canyon in lower left.

welded ash-flow tuff because it shows vague columnar jointing (fig. 25), a feature common in ash-flow tuffs but not in air-fall tuffs, and because it is massive (fig. 27) and unsorted. Furthermore, the subunit thins against older rocks (rhyolite-obsidian, figs. 27 and 28, and andesite of Depression Canyon west of Cave Canyon, fig. 2) instead of maintaining a more uniform thickness as would an air-fall tuff.

The upper unit (up to $10 \mathrm{~m}$ or more), the most extensive unit, is a cliff- and slope-forming white to tan air-fall and partly reworked lithic tuff containing large angular lapilli of lump pumice and rhyolite-obsidian. It is characterized by northeast- and northwest-trending joints along which narrow, deep crevices have developed, especially on Hells Half Acre, between Whitewash and Hells Half Acre Canyons (fig. 2).

The Hells Half Acre Tuff Member was not studied in detail, so the extent and amount of zeolitization are

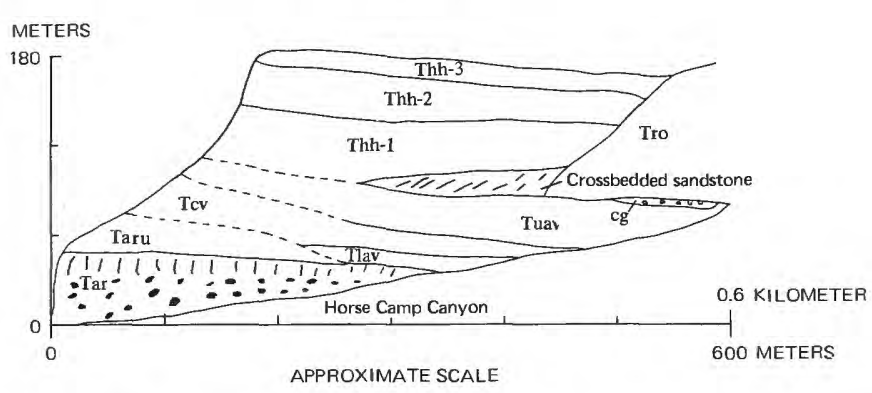

FIgURE 26.-Diagrammatic sketch of northwest wall of Horse Camp Canyon, above Aravaipa Canyon, showing units of Hells Half Acre Tuff Member (air-fall and reworked tuff, Thh-3; ash-flow(?) tuff, Thh-2; water-laid tuff, Thh-1) and relations of rhyolite-obsidian member (Tro) to Hells Half Acre Tuff Member and to upper andesite of Virgus Canyon (Tuav). Exposed contacts (only locally covered with talus) are solid lines; inferred contacts are dashed. Upper andesite of Virgus Canyon locally separated from rhyoliteobsidian by conglomerate (cg) and from lower unit of Hells Half Acre Tuff Member by a wedge of crossbedded sandstone, washed out from the brecciated nose of rhyolite-obsidian flow. Conglomerate of Virgus Canyon (Tcv); lower andesite of Virgus Canyon (Tlav), and Aravaipa Member (Tar, showing vuggy and columnar-jointed zones and overlying slightly welded zone, Taru).

not known. The compositions of six random specimens of the tuff, estimated from X-ray diffractographs, are shown in figure 29. Four of the specimens (all from the middle unit) have been largely altered to clinoptilolite; the others are vitric. The altered tuff is pink or white; the pumice lapilli are pink, white, or pale brown. A chemical analysis of a specimen of altered tuff and an analysis of a specimen of unaltered rhyolite-obsidian are listed in table 7 together with the analyses recalculated without $\mathrm{H}_{2} \mathrm{O}$. The zeolitic alteration of the tuff accounts for the higher $\mathrm{CaO}$ and lower $\mathrm{Na}_{2} \mathrm{O}$ content. Relative amounts of $\mathrm{CaO}, \mathrm{Na}_{2} \mathrm{O}$, and $\mathrm{K}_{2} \mathrm{O}$ are plotted in figure 24. The minor-element analysis is given in table 4. Zeolitic alteration makes it impossible to tell if the two were originally chemically similar. Additional data on Hells Half Acre Tuff Member is given in Krieger, Johnson and Bigsby (1979).

The Hells Half Acre Tuff Member may be part of the same volcanic episode as the rhyolite-obsidian member, although eruption of flows and tuffs may have alternated. The relations on the north side of Aravaipa Canyon east of Javalina Canyon (fig. 27) suggest that an obsidian flow and the overlying middle unit of Hells Half Acre Tuff are contemporaneous. Obsidian breccia underlies, overlies, and wraps around the nose of the flow. Immediate burial by the tuff probably preserved the breccia from erosion. The relations between rhyolite-obsidian and the lowest unit of the tuff, as exposed in Horse Camp Canyon (fig. 25), however, suggest sufficient time for erosion to form the wedge of crossbed- 

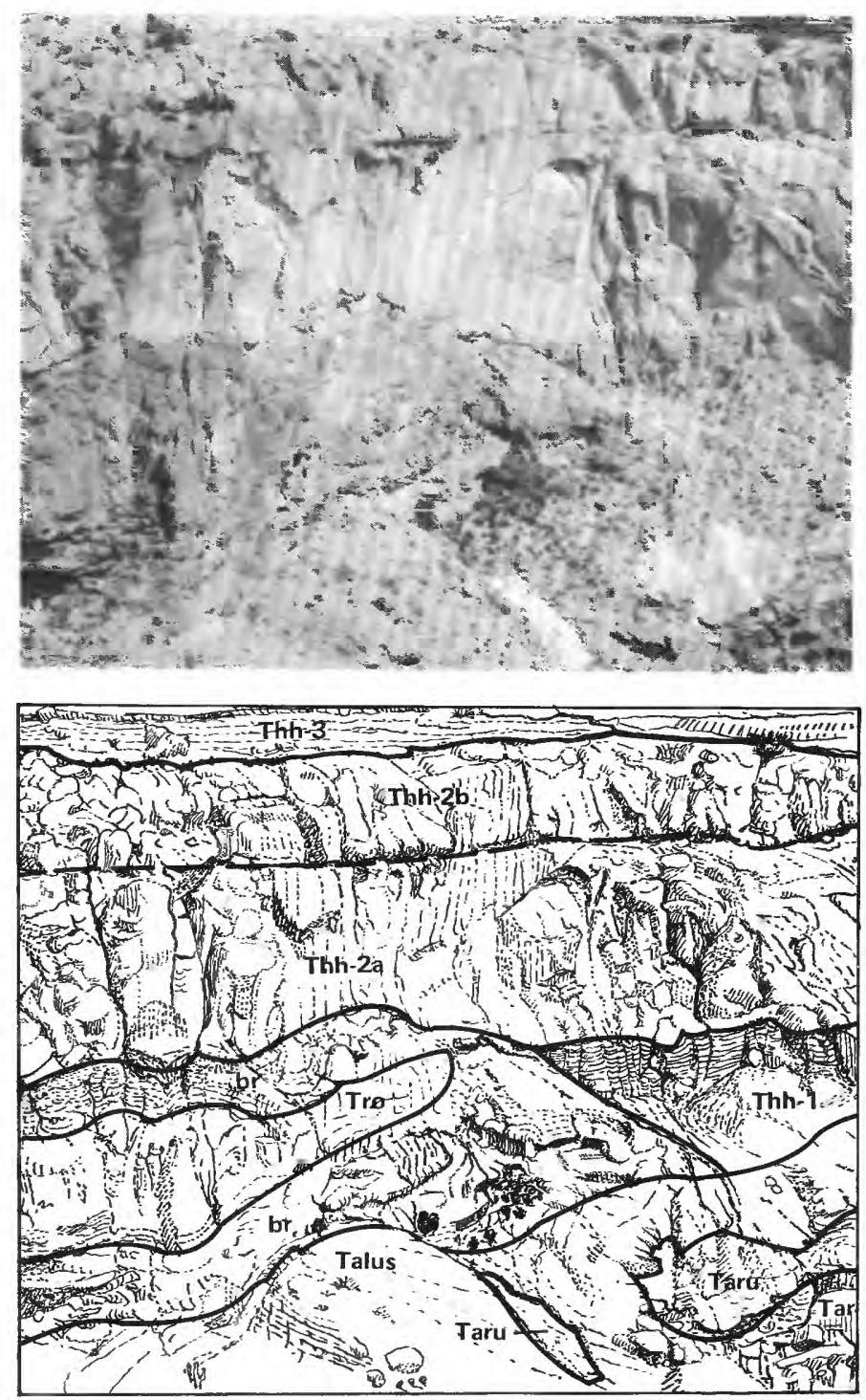

0.15 KILOMETER

Approximate scale

Figure 27.-Massive lower part of middle unit (Thh-2a) of Hells Half Acre Tuff Member and its relation to rhyolite-obsidian member (Tro) (see sketch). Unit thins over irregular surface of flow, but maintains a horizontal top. This flow impounded water in which lower unit (Thh-1) of tuff was deposited. Flow consists of brecciated (br) and nonbrecciated (Tro) material. Upper part of middle unit (Thh-2b) is overlain by upper unit (Thh-3). Aravaipa Member (upper slightly welded tuff, Taru, and cliff-forming, columnarjointed and vuggy zones, Tar) underlies talus-covered slope concealing conglomerate and possibly andesite of Virgus Canyon. View northeast from west of mouth of Virgus Canyon.

ded sandstone that is composed of material derived from the brecciated rhyolite-obsidian flow. Finally, some of the large angular airborne(?) lapilli of rhyolite-obsidian and lump pumice that are abundant in the upper unit of the tuff may have come from the vent

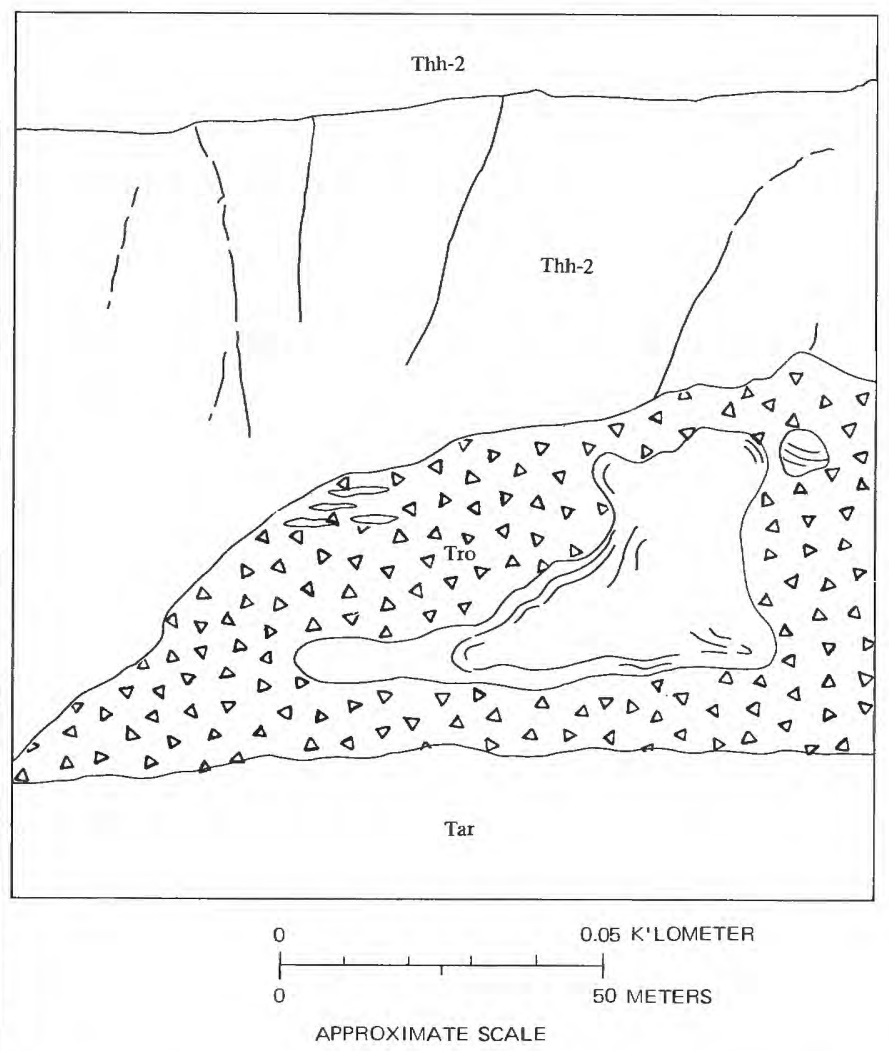

FIGURE 28.-Diagrammatic sketch showing relations of middle unit (Thh-2) of Hells Half Acre Tuff Member and rhyolite-obsidian member (Tro). Massive lower part of middle unit has horizontal top and very irregular base, suggesting ash-flow rather than air-fall origin. Interior of obsidian flow (Tro) is flow banded; its margins are brecciated. Preservation of fragmented nose and top of obsidian flow suggests that it was almost immediately covered by Hells Half Acre Tuff Member. Aravaipa Member (Tar) underlies rhyolite-obsidian member. Composite of exposures on north side of Aravaipa Canyon east of Javalina Canyon.

in the rhyolite-obsidian near the boundary between the Klondyke and Holy Joe Peak quadrangles north of Aravaipa Canyon. These may represent the last major eruption of this sequence. To date no conclusive proof of intermittent eruption of rhyolite-obsidian flows has been found. The relations shown in figure 27 , however, suggest that the rhyolite-obsidian flow here may be slightly older than both the lower and middle units of the tuff.

\section{SUGGESTIONS FOR FUTURE WORK}

The Holy Joe and Aravaipa Members of the Galiuro Volcanics are so well exposed and so clearly show characteristic features of ash-flow tuffs that they could be a valuable teaching aid, and a source of theses for geology students. Many detailed studies could be undertaken, for instance: (1) searching for flow boundaries and lithologic and chemical changes across flows in the 


\begin{tabular}{|c|c|c|c|c|c|c|c|c|}
\hline $\begin{array}{l}\text { Sample } \\
\text { number }\end{array}$ & $\begin{array}{l}\frac{ \pm}{ \pm \pi} \\
\frac{ \pm}{0} \\
0 \\
\frac{n}{2} \\
0\end{array}$ & $\frac{2}{\frac{2}{0}}$ & $\underset{\frac{N}{N}}{\frac{N}{3}}$ & $\frac{\stackrel{ \pm}{ \pm}}{\frac{0}{0}}$ & 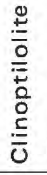 & $\frac{\pi}{0}$ & $\begin{array}{l}n \\
0 \\
0 \\
0\end{array}$ & $\begin{array}{l}\text { - Abundant (more than } \\
50 \text { percent) } \\
\text { O Present but not abundant } \\
\triangle \text { Recognized } \\
\text { - Not recognized }\end{array}$ \\
\hline H180A & - & $\triangle$ & $\Delta$ & - & $\triangle$ & - & - & Upper unit (air-fall tuff) \\
\hline $\mathrm{H} 276$ & - & $\triangle$ & o & - & - & - & - & Middle(?) unit \\
\hline $\mathrm{H} 342 \mathrm{~A}$ & - & o & 0 & $\triangle$ & - & $一$ & - & Middle unit (ash-flow tuff) \\
\hline H344 & - & $\triangle$ & 0 & $\triangle$ & - & - & - & Middle unit (ash-flow tuff) \\
\hline $\mathrm{H} 410$ & - & $\triangle$ & $\triangle$ & $\triangle$ & - & - & - & Middle unit (ash-flow tuff) \\
\hline H410A & - & $\triangle$ & $\triangle$ & - & - & - & - & Upper(?) unit (air-fall tuff) \\
\hline
\end{tabular}

FiguRE 29.-Approximate composition of Hells Half Acre Tuff Member, estimated from X-ray diffractographs of bulk samples. H180A, middle branch, Hells Half Acre Canyon, center sec. 20, T. 6 S., R. 18 E. (fig. 2). Contains trace of calcite. H276, Ash Creek, east of Lyon Camp, sec. 21, T. 5 S., R. 18 E., NW11/4 Brandenburg Mountain quadrangle; H342A, Cave Canyon, NW11/4 sec. 18, T. 6 S., R. 19 E. (fig. 2); H344, Aravaipa Canyon, east of Cave Canyon, NW $1 \frac{1}{4}$ sec. 18 , T. 6 S., R. 18 E. (fig. 2); H410, Aravaipa Canyon, near mouth of Cave Canyon, NW1/4 sec. 18, T. 6 S., R. 18 E. (no. 12, fig. 2). (Chemical analysis, see table 7); H410A, Horse Camp Canyon, SW cor. sec. 9, T. 6 S., R. 18 E. (fig. 2).

Holy Joe Member, as well as more detailed study of the upper vitrophyre and its distribution than has been made; (2) studying the ash-flow tuff sheet of the Aravaipa Member to determine if it is made up of more than one flow; making a careful selection of samples so as to obtain more meaningful results of changes in chemical composition of glassy and crystalline parts of both ash-flow tuffs and of changes due to zeolitization in the Aravaipa Member; (3) examining the relation of the tuff of Bear Springs Canyon to the tuff of Aravaipa Member to determine if they make up a composite sheet (Smith, 1960a); (4) determining the age relations of rhyolite-obsidian member and Hells Half Acre Tuff Member and the distribution of zeolitization in the tuff.

\section{REFERENCES CITED}

Blake, W. P., 1902, The geology of the Galiuro Mountains, Ariz., and of the gold-bearing ledge known as Gold Mountain: Engineering Mining Journal, v. 73, p. 546-547.

Buddington, A. F., and Lindsley, D. H., 1964, Iron-titanium oxide minerals and synthetic equivalents: Journal of Petrology, v. 5, p. $310-357$.

Carmichael, I. S. E., 1967, The iron-titanium oxides of salic volcanic rocks and their associated ferromagnesian silicates: Contributions to Mineralogy and Petrology, v. 14, p. 36-64.

Cooper, J. R., and Silver, L. T., 1964, Geology and ore deposits of the Dragoon quadrangle, Cochise County, Arizona: U.S. Geological Survey Professional Paper 416, 196 p.

Creasey, S. C., and Krieger, M. H., 1978, The Galiuro Volcanics, Pinal, Graham, and Cochise Counties, Arizona: U.S. Geological Survey Journal of Research. v. 6, no. 1, p. 115-131.
Hoover, D. L., 1966, Physical and chemical changes during zeolitization of vitric tuffs and lava flows, Nevada Test Site [abs.]: Geological Society of America Special Paper 87, p. 286-287.

-1968 , Genesis of zeolites, Nevada Test Site, in Eckel, E. B., ed., Nevada Test Site: Geological Society of America Memoir 110 , p. 275-284.

Hoover, D. L., and Shepard, A. O., 1965, Zeolite zoning in volcanic rocks at the Nevada Test Site, Nye County, Nevada [abs.]: American Mineralogist, v. 50, nos. 1-2, p. 287.

Krieger, M. H., 1968a, Geologic map of the Brandenburg Mountain quadrangle, Pinal County, Arizona: U.S. Geological Survey Geologic Quadrangle Map GQ-668, scale 1:24,000.

1968 b, Geologic map of the Holy Joe Peak quadrangle, Pinal County, Arizona: U.S. Geological Survey Geologic Quadrangle Map GQ-669, scale 1:24,000.

-1968 c, Geologic map of the Lookout Mountain quadrangle, Pinal County, Arizona: U.S. Geological Survey Geologic Quadrangle Map GQ-670, scale 1:24,000.

-1968d, Geologic map of the Saddle Mountain quadrangle, Pinal County, Arizona: U.S. Geological Survey Geologic Quadrangle Map GQ-671, scale 1:24,000.

Krieger, M. H., Johnson, M. G., and Bigsby, P. R., 1979, Mineral resources of the Aravaipa Canyon Designated Wilderness area. Pinal and Graham Counties, Arizona: U.S. Geological Survey Open-File Report 79-291, 183 p.

Lipman, P. W., 1965, Chemical comparison of glassy and crystalline volcanic rocks: U.S. Geological Survey Bulletin 1201-D, 24 p.

Lipman, P. W., and Christiansen, R. L., 1964, Zonal features of an ash-flow sheet in the Piapi Canyon Formation, southern Nevada, in Geological Survey Research, 1964: U.S. Geological Survey Professional Paper 501-B, p. B74-B78.

Lipman, P. W., Christiansen, R. L., and O'Connor, J. T., 1966, A compositionally zoned ash-flow sheet in southern Nevada: U.S. Geological Survey Professional Paper 524-F, 47 p.

Ratté, J. C., and Steven, T. A., 1967, Ash flows and related volcanic rocks associated with the Creede caldera, San Juan Mountains, Colorado: U.S. Geological Survey Professional Paper 524-H, $58 \mathrm{p}$.

Ross, C. S., and Smith, R. L., 1955, Water and other volatiles in volcanic glasses: American Mineralogist, v. 40, nos. 11-12, p. $1071-$ 1089 .

-1961, Ash-flow tuffs-Their origin, geologic relations, andidentification: U.S. Geological Survey Professional Paper 366, 81 p.

Shapiro, Leonard, 1967, Rapid analyses of rocks and minerals by a single solution method, in Geological Survey Research 1967: U.S. Geological Survey Professional Paper 575-B, p. B187B191.

Shapiro, Leonard, and Brannock, W. W., 1962, Rapid analysis of silicate, carbonate, and phosphate rocks: U.S. Geological Survey Bulletin 1144-A, $56 \mathrm{p}$.

Sheppard, R. A., and Gude, A. J., 3d, 1965, Zeolitic authigenesis of tuffs in the Ricardo Formation, Kern County, California, in Geological Survey Research, 1965: U.S. Geological Survey Professional Paper 525-D, p. D44-D47.

Simons, F. S., 1964, Geology of the Klondyke quadrangle, Graham and Pinal Counties, Arizona: U.S. Geological Survey Professional Paper 461, $173 \mathrm{p}$.

Smith, R. L., 1960a, Ash flows: Geological Society of America Bulletin, v. 71 , no. 6 , p. $795-841$.

$1960 \mathrm{~b}$, Zones and zonal variations in welded ash flows: U.S. Geological Survey Professional Paper 354-F, p. F149-F159.

Willden, Ronald, 1964, Geology of the Christmas quadrangle, Gila and Pinal Counties, Arizona: U.S. Geological Survey Bulletin 1161-E, $64 \mathrm{p}$. 